\title{
DISTRIBUIÇÃO DE BACTÉRIAS PLANCTÔNICAS, COLÔNIAS BACTERIANAS E BIOFILMES MICROBIANOS EM DENTES DECÍDUOS COM PULPITE E OU NECROSE PULPAR
}

\section{VALÉRIA LOPES DE GODOY}

Tese apresentada à Faculdade de Odontologia de Bauru da Universidade de São Paulo, como parte dos requisitos para a obtenção do título de Doutor em Odontologia, área de Odontopediatria.

\section{BAURU}

1999 


\section{DISTRIBUIÇÃO DE BACTÉRIAS PLANCTÔNICAS, COLÔNIAS BACTERIANAS E BIOFILMES MICROBIANOS EM DENTES DECÍDUOS COM PULPITE E OU NECROSE PULPAR}

\section{VALÉRIA LOPES DE GODOY}

Tese apresentada à Faculdade de Odontologia de Bauru da Universidade de São Paulo, como parte dos requisitos para a obtenção do título de Doutor em Odontologia, área de Odontopediatria.

(Edição Revista)

Orientador: Prof. Dr. Alberto Consolaro

\section{BAURU}

1999 


\section{Ficha Técnica}

Valéria Lopes de Godoy - concepção original, experimento, redação, digitação, ilustração

Alberto Consolaro - concepção original, orientação e ilustração

William Gomes Felício - formatação e impressão

Fátima Aparecida Silveira - histotécnica

André Luis da Silva - histotécnica

Valdir João Afonso - revisão final e vernáculo

Valéria Cristina T. Ferraz - normatização técnica

Marcus Thame - cópias e encadernação

Godoy, Valéria Lopes

G548p Distribuição de bactérias planctônicas, colônias bacterianas e biofilmes microbianos em dentes decíduos com pulpite e ou necrose pulpar / Valéria Lopes de Godoy - - Bauru, 1999.

151 p.: il.; $28 \mathrm{~cm}$.

Dissertação. (Doutorado) - Faculdade de Odontologia de Bauru. USP.

Orientador: Prof. Dr. Alberto Consolaro

Autorizo, exclusivamente para fins acadêmicos e científicos, a reprodução total ou parcial desta tese, por processos fotocopiadores e outros meios eletrônicos.

Assinatura do autor:

Data: Bauru 19 de novembro de 1999. 


\section{Valéria Lopes de Godoy}

12 de novembro de 1968 Bauru-SP

Filiação

1987-1990

1991

$1992-1995$

$1995-1999$

Associações
Nascimento

Sebastião Lopes de Godoy Neto Doracy Pellegrina de Godoy

Curso de Graduação em Odontologia pela

Faculdade de Odontologia de Lins

Curso de Atualização em Odontopediatria, promovido pelo Hospital de Pesquisa e Reabilitação de Lesões Lábio-Palatais em convênio com a PROFIS

Curso de Pós-Graduação em Odontopediatria, em nível de Mestrado, pela Faculdade de Odontologia de Bauru - USP

Curso de Pós-Graduação em Odontopediatria, em nível de Doutorado, pela Faculdade de Odontologia de Bauru - USP

APCD - Associação Paulista de Cirurgiões-Dentistas

SBPqO - Sociedade Brasileira de Pesquisa Odontológica 
Se puderes guardar o sangue frio diante de quem fora de si te acusar; e, no instante em que duvidem de teu ânimo e firmeza, tu puderes ter fé na própria fortaleza, sem desprezar contudo a confiança alheia...

Se tu puderes não odiar a quem te odeia, nem pagar com a calúnia a quem te calunia, sem que tires daí motivos de ufania; sonhar, sem permitir que o sonho te domine; pensar, sem que em pensar tua ambição se confine; e esperar sempre e sempre, infatigavelmente...

Se com o mesmo sereno olhar indiferente puderes encarar a Derrota e a Vitória, como embustes que são da fortuna ilusória; e estóico suportar que intrigas e mentiras deturpem a palavra honesta que profiras...

Se puderes, ao ver em pedaços destruída pela sorte maldosa, a obra de sua vida, tomar de novo, a ferramenta desgastada e sem queixares vãos, recomeçar do nada...

Se, tendo loucamente arriscado e perdido tudo quanto era teu, num só lance atrevido, tu puderes voltar à faina ingrata e dura, sem aludir jamais à sinistra aventura...

Se tu puderes coração, músculos , nervos reduzir da vontade à condição de servos, que, embora exausto, lhe obedeçam ao comando...

Se, andando a par dos reis e com os grandes lidando, puderes conservar a naturalidade, e no meio da turba a personalidade; impávido afrontar adulações, engados, opressões; merecer a confiança de todos, sem que possa contar, todavia contigo incondicionalmente o teu melhor amigo...

Se cada minuto os sessenta segundos tu puderes tornar com o teu suor fecundos... a Terra, será tua, e os bens que se não somem, e, o que é melhor, meu filho, então serás um Homem! 


\section{Agradeço e dedico este trabalho}

\section{A DEUS,}

Incomparável e Inconfundível na sua infinita bondade, compreende meus anseios dando-me a necessária coragem para atingir meus objetivos;

Aos meus pais Sebastião e Doracy

pela dedicação, doação e dignidade, que orientam minha formação;

Ao meu marido, William, sempre presente proporcionando-me estímulo para a realização deste trabalho;

\section{À Aline e à Mariana}

Minhas filhas por natureza, opção e amor, por todos os momentos em que estive ausente. 
Agradecimentos Pessoais

Aos meus irmãos, Wagner e Denise pelo apoio, carinho e amizade que sempre nos uniu;

Aos Professores do Departamento de Odontopediatria da Faculdade de Odontologia de Bauru - USP, Dr. Aymar, Dr. José Eduardo, Dr. Ruy, Dr. Vono, Dra. Maria Aparecida, Dra. Maria Francisca e Dra. Salete pela convivência amiga e pelos conhecimentos transmitidos no decorrer do curso;

Aos Professores Dr. Alberto, Dra. Denise, Dr. Luís Antônio e Dra. Vanessa e aos funcionários Sr. Valdir, Cristina, Fátima e Bernadete do Departamento de Patologia da Faculdade de Odontologia de Bauru - USP, minha amizade e consideração pela maneira carinhosa que sempre me receberam;

Aos Professores da Faculdade de Odontologia de Lins e aos Professores do Curso de Pós-Graduação da Faculdade de Odontologia de Bauru - USP, pelos valiosos ensinamentos, responsáveis pela minha formação profissional;

Aos Colegas do curso de Pós-Graduação, Bia, Max, Cadú, e especialmente a Nildinha pelos anos de convivência e pela amizade buscando o mesmo ideal; 
Aos Funcionários da Disciplina de Odontopediatria, Dona Lia, Dona Wilma, Liliam, Maria Estela, Sr. Walter, Fátima e Paulo pela contribuição e pela amizade durante os momentos que convivemos;

À Fátima Aparecida Silveira pela amizade e atenção no preparo e obtenção das lâminas;

Ao C.D. Marco Antônio Ferreira da Cunha pela ajuda dispensada durante a fase de obtenção das amostras;

Ao Sr. Valdir João Afonso pela amizade e extrema competência na correção do vernáculo;

A todos os Funcionários da Biblioteca, pela atenção e carinho com que sempre atenderam æ̀ minhas solicitações; 


\title{
Agradecimentos Institucionais
}

\begin{abstract}
À Direção da Faculdade de Odontologia de Bauru - USP, na pessoa do Diretor Professor Doutor Aymar Pavarini pela oportunidade concedida;
\end{abstract}

Ao Setor de Pós-Graduação da Faculdade de Odontologia de Bauru USP, pela atenção que sempre me dispensaram;

Ao Conselho Nacional de Desenvolvimento Científico e Tecnológico (CNPq), pela concessão da bolsa de estudo; 
Ao professor Doutor Aymar Pavarini, grande incentivador em todos os momentos do meu curso. Pelos ensinamentos, atenção e dedicação com que sempre me recebeu e também inestimável amizade.

Meu agradecimento especial 
Ao Professor Doutor Alberto Consolaro, mestre exemplar, que com indescritível capacidade e dedicação norteou os rumos deste trabalho compartilhando comigo seus conhecimentos, honrando-me com sua amizade e consideração.

Minha eterna gratidão e admiração 


\section{SUMÁRIO}

RESUMO Xii

1 INTRODUÇÃO

2 REVISÃO DA LITERATURA 6

2.1 Presença de bactérias nos tecidos mineralizados, pulpares

$\begin{array}{ll}\text { e periapicais } & 7\end{array}$

2.2 Conceitos atuais de biofilmes microbianos 53

3 PROPOSIÇÃO

4 MATERIAL E MÉTODOS 61

$\begin{array}{ll}\text { 4.1 Amostragem } & 62\end{array}$

4.1.1 Obtenção das amostras 62

4.1.2 Seleção das amostras $\quad 62$

4.1.3 Distribuição das amostras $\quad 62$

4.1.4 Preparação das amostras 62

4.1.5 Análise microscópica 70

$\begin{array}{ll}\text { 4.1.6 Fotomicrografias } & 70\end{array}$

5 RESULTADOS

5.1 Grupo A - Dentes cortados longitudinalmente 72

5.1.1 Observações relativas àcâmara pulpar e canal radicular 72

5.1.2 Observações relativas à dentina 73 
5.1.3 Observações relativas àregião apical 74

5.2 Grupo B - Dentes cortados transversalmente 79

5.2.1 Observações relativas àcâmara pulpar e canal radicular $\quad 79$

$\begin{array}{ll}\text { 5.2.2 Observações relativas à dentina } & 80\end{array}$

5.2.3 Observações relativas àregião apical 80

Ilustrações Fotográficas $\quad 85$

6 DISCUSSÃO 104

7 CONCLUSÕES 128

REFERÊNCIAS BIBLIOGRÁFICAS 131

$\begin{array}{ll}\text { ABSTRACT } & 149\end{array}$ 


\section{RESUMO}

As bactérias constituem fatores primordiais da contaminação da polpa dentária de dentes decíduos resultando em implicações clínicas e terapêuticas. Com a finalidade de analisar a presença de bactérias planctônicas, colônias bacterianas e biofilmes microbianos nas estruturas de dentes decíduos portadores de pulpite e necrose pulpar, utilizaram-se 32 dentes decíduos com cárie profunda. Dezesseis dentes foram seccionados no sentido longitudinal e os outros dezesseis no sentido transversal. Os espécimes foram corados pela hematoxilina-eosina de Harris e Brown e Brenn para análise pela microscopia óptica. A partir da metodologia empregada pôde-se verificar que:

1- em dentes decíduos com pulpite decorrente de cárie dentária, as bactérias podem ser encontradas nos túbulos dentinários e especialmente no interior do tecido pulpar na área inflamada. Colônias bacterianas e biofilmes microbianos são visualisados na superfície cariosa e nos focos de liquefação dentinária;

2- as bactérias planctônicas, colônias bacterianas e biofilmes microbianos estão abundantemente presentes nas câmaras pulpares e canais radiculares de dentes decíduos com necrose pulpar, localizando-se nas superfícies do teto, do soalho da câmara pulpar a nas paredes laterais do canal radicular e, por extensão, nas paredes externas apicais;

3- na estrutura dentinária de dentes decíduos com necrose pulpar, as bactérias se alojam nos túbulos dentinários da região da cárie 
dentária, afetando-os no sentido externo-interno e, nas paredes da câmara pulpar e do canal radicular, no sentido interno-externo;

4- no terço apical dos dentes decíduos com necrose pulpar, as bactérias se alojam nos túbulos dentinários e chegam freqüentemente até a superfície externa radicular a partir das áreas de reabsorções próprias da rizólise, estabelecendo-se colônias bacterianas e biofilmes microbianos.

Os resultados permitiram concluir que apesar dos procedimentos e cuidados tecnicamente assumidos e da evolução dos produtos e medicamentos colocados nas cavidades preparadas, na câmara pulpar e nos canais radiculares com finalidades de curativo de demora, obturadora e ou restauradora, não é possível clinicamente afirmar que todas as bactérias, colônias bacterianas e biofilmes microbianos serão eliminados, especialmente quando os dentes decíduos apresentam-se com necrose pulpar. 
1 INTRODUÇÃO 


\section{INTRODUÇÃO}

A manutenção dos dentes decíduos até sua época normal de esfoliação tem importância fundamental para o desenvolvimento bucomaxilofacial da criança. Os dentes decíduos são os responsáveis pelo crescimento e desenvolvimento normal das estruturas ósseas maxilares, interferem na harmonia do conjunto facial, respondem pelo posicionamento dos dentes permanentes e pela postura lingual, labial e das estruturas dos tecidos moles da boca.

A prevenção vista de forma consciente e global, desde o período de gestação até o irrompimento dos dentes decíduos seria ideal. Para atingir esta meta, torna-se necessário apresentar à sociedade objetivos e resultados, utilizandose de forte persistência de todas as partes envolvidas no processo de prevenção, para que os resultados sejam satisfatórios Inclusive, deve-se ressaltar as consequiências da falta de medidas preventivas no contexto individual e comunitário.

No Brasil, o exercício profissional na área de saúde tem priorizado a doença; as ações médico-odontológicas têm sido predominantemente curativas e no estágio avançado. Grande número de crianças não tem acesso aos métodos preventivos; a incidência da cárie dentária na dentição decídua passa a ser altamente significante e o envolvimento pulpar é maior do que se imagina, e quase sempre evolui para necrose pulpar. A contaminação da polpa pode ter origens diversas, mas a cárie dentária pode ser considerada a causa principal. Embora não seja conhecido o momento exato em que as bactérias e/ou seus produtos ganham acesso ao tecido pulpar, sob a cárie em dentina há uma reação inflamatória ${ }^{7}$. A 
evolução da pulpite instalada está na dependência das condições locais e da virulência da microbiota local com influência do estado de saúde geral do paciente.

A necrose pulpar implica na parada dos processos metabólicos desse órgão, com a conseqüente perda de sua estrutura, bem como de suas defesas naturais. A exposição e o tecido pulpar em decomposição irão permitir o livre acesso dos microrganismos ao canal radicular e oferecer as condições ideais para a proliferação, formação de colônias bacterianas e biofilmes microbianos. As bactérias e seus produtos, mais os derivados da desintegração pulpar, representam as principais e mais freqüentes causas de periapicopatias.

Os microrganismos mais freqüentemente isolados em tecido pulpar infectado são provenientes da cavidade bucal ${ }^{32,90,106}$, sem descartar a via hematogênica anacorética ou não ${ }^{99}$. A microbiota dos canais radiculares infectados inclui um grupo restrito de espécies microbianas ${ }^{3,98}$. O microambiente nos túbulos dentinários coronários e dos radiculares, favorece o crescimento específico de certas espécies microbianas. Isto implica em seletividade exercida por fatores intrínsicos e extrínsecos sobre esta microbiota ${ }^{88,89}$.

Com o aprimoramento das técnicas de culturas em anaerobiose, tem-se observado uma maior presença de microrganismos anaeróbios nas infecções pulpares, caracterizando a microbiota dos canais radiculares, como predominantemente anaeróbia ${ }^{3,12,27,28,31,33,39,40,41,46,60,89,90,91,98,99,103,105,106,107}$. Bactérias aeróbias e anaeróbias facultativas também participam desta microbiota, principalmente na região coronária de dentes com exposição pulpar por cárie. 
Infecções anaeróbias ocorrem na presença de um suprimento sangüíneo compromissado ou infecção antecedente por bactérias aeróbias e facultativas, ambos produzem baixo potencial de redução de oxigênio. Anaeróbios correspondem a uma microbiota de invasores secundários, difundindo-se além dos limites da polpa e periápice ${ }^{32}$.

Nos dentes decíduos, lesões periodontais podem ser causadas por patologia pulpar. Alterações patológicas ósseas em molares decíduos seguida de inflamação pulpar não são encontradas na região apical, mas localizam-se na área inter-radicular. A região da dentina do soalho da câmara pulpar de dentes decíduos em rizólise foi denominada de "peneira biológica" a partir da análise em microscopia eletrônica de varredura ${ }^{36,37}$.

O tratamento pulpar de dentes decíduos apresenta alguns obstáculos, que tem como ponto de partida aspectos anatômicos e fisiológicos próprios dos dentes decíduos ${ }^{5,6,45,86}$. Diferentes técnicas têm sido propostas para o tratamento de dentes decíduos. O emprego de técnicas endodônticas adequadas permitem a eliminação de grande parte dos microrganismos; o índice de sucesso é significante. A presença e permanência de bactérias nos túbulos dentinários, no sistema de canais radiculares e na forma de placas dentobacterianas e biofilmes na superfície radicular, podem manter os processos biológicos inflamatórios, reabsortivos e as respostas celulares frente aos agressores locais retardando ou mesmo impedindo o processo de reparo. Podem assim causar danos ao germe do dente permanente. 
A presença de bactérias nas estruturas dos dentes decíduos tem importância fundamental no prognóstico, pois as superfícies internas e externas são naturalmente irregulares pela presença de lacunas de Howship e franca exposição dos túbulos dentinários, ambos em decorrência da rizólise, iniciada logo após completa rizogênese. Nestas superfícies, a colonização em forma de biofilmes microbianos dificultam a terapêutica pela maior resistência bacteriana adquirida, pois uma placa de polissacarídeos especiais as protege ainda mais das ações de substâncias anti-sépticas e antibióticos.

Algumas metodologias foram aplicadas com o propósito de verificar a distribuição de bactérias nos tecidos pulpares e periapicais dos dentes permanentes e em tecido ósseo ${ }^{10,76,77}$. Nos dentes decíduos, pouco se conhece sobre a presença das bactérias na forma planctônica*, em colônias bacterianas e em biofilmes microbianos nas estruturas mineralizadas e tecidos pulpares de dentes com pulpites e necrose pulpar.

\footnotetext{
* Plâncton ou plancto - denominação coletiva dada a organismos que vivem suspensos nas camadas superfíciais do mar ou da água doce, onde constituem a base dos ecossistemas. Rico em algas unicelulares, bactérias e protozoários, o plâncton inclui também crustáceos, moluscos, celenterados e representantes de quase todos os outros filos de animais ${ }^{72}$.
} 
2 REVISÃO DA LITERATURA 


\section{REVISÃO DA LITERATURA}

Neste capítulo, serão abordados dois aspectos: a presença de bactérias nos tecidos mineralizados, pulpares e periapicais e conceitos atuais de biofilmes microbianos.

\subsection{Presença de bactérias nos tecidos mineralizados, pulpares e} periapicais

Em restos necróticos pulpares, MILLER ${ }^{59}$, em 1894, observou uma extensa variedade de células bacterianas, sugerindo microbiotas diferentes em dentes com câmaras pulpares expostas ao meio bucal quanto à localização, se na câmara pulpar ou no canal radicular.

Para avaliar dentes com ausência de cárie ou restaurações extensas, porém sem vitalidade pulpar como conseqüência de trauma, em 1957, BROWN; RUDOLPH $^{14}$, selecionaram 70 dentes permanentes humanos e empregando culturas aeróbia e anaeróbia, microscopia de contraste de fase de campo escuro e também óptica encontraram bactérias em $90 \%$ dos espécimes. Os anaeróbios estritos e facultativos constituíram cerca de $25 \%$ e os aeróbios $51 \%$. Streptococcus alfa e gama hemolíticos, difteróides e espécies de Micrococcus foram encontrados freqüentemente. Destacou-se a importância da utilização da microscopia no estudo da microbiota dos canais radiculares, pois por meio desta técnica, foi possível detectar vibriões, espiroquetas e fusiformes, que não apresentaram crescimento em meio de cultura. 
O conteúdo bacteriológico da câmara pulpar de 46 dentes humanos anteriores, 39 permanentes e 7 decíduos, com coroas intactas e sem vitalidade pulpar em decorrência de trauma, foram analisados por meio de métodos adequados de aero e anaerobiose por MAC DONALD; HARE; WOOD ${ }^{57}$, em 1957. Isolaram 71 cepas bacterianas das amostras dos canais obtidas de 38 espécimes; $32 \%$ dos microrganismos isolados eram anaeróbios estritos. Nas amostras com culturas positivas, o intervalo entre a agressão e a cultura variou entre duas semanas e 20 anos; em oito casos, nos quais nenhum crescimento foi detectado, este período variou entre um mês e três anos. Para os autores, a maioria das bactérias alcança a polpa dos dentes que sofreram trauma dentário sem fratura, via vasos linfáticos e sanguiíneos do periodonto e podem ser a causa de necrose pulpar.

COHEN et $\mathrm{al}^{21}$, em 1960, realizaram estudo bacteriológico em molares decíduos necrosados de 30 crianças entre 4 e 8 anos de idade. Todos espécimes mostraram destruição óssea na região de furcação das raízes e em alguns casos presença de fístula. Após isolamento absoluto, um penso de algodão estéril foi introduzido, via abertura oclusal da lesão de cárie, sobre o soalho da câmara pulpar por um minuto. Após este período, o algodão foi desintegrado em solução de soro fisiológico estéril e os organismos foram suspensos na solução salina de onde se colheram amostras para cultura em placa de agar sangue. A partir da subcultura em aero e anaerobiose, verificaram que Streptococcus salivarius foram encontrados em $70 \%$ da amostra, seguido pelos Staphylococcus albus 23\%, Enterobacillus 17\%, Lactobacilos 13\%, Streptococcus mitis 10\%, Streptococcus beta hemolíticos 10\%, Staphylococcus aureus 5\%, Neisseria catarralis 3\% e lêvedos $3 \%$. Os autores concluíram que não se deve manter aberto, dente decíduo 
infectado na boca de criança devido à variedade de microrganismos nocivos, os dentes deverão ser extraídos ou tratados endodonticamente dependendo do grau de infecção.

Para verificar a invasão de bactérias nos túbulos dentinários de dentes permanentes sem vitalidade pulpar, em 1961, CHIRNSIDE ${ }^{20}$, imediatamente após a extração de cinco pré-molares humanos intactos, removeu o esmalte da superfície oclusal tornando uma superfície áspera para facilitar o acúmulo de placa bacteriana. Na altura da junção amelocementária, foi realizado o seccionamento da coroa com um disco diamantado estéril e eliminação da polpa coronária via apical que posteriormente foi selada com cemento de fosfato de zinco. Os espécimes foram fixados na região de molar de uma prótese parcial removível inferior, permitindo a exposição da dentina da superfície oclusal preparada, ao meio bucal. Após 3, 4 e 5 semanas, os dentes foram removidos, processados e submetidos à coloração de Gram para análise microscópica. Como controle, outros cinco prémolares nas mesmas condições foram tratados de modo similar, todavia o esmalte oclusal não foi removido. Pôde-se verificar a presença de placas dentobacterianas aderidas à superfície oclusal e bactérias no interior de alguns túbulos dentinários subjacentes. A proporção de bactérias nos túbulos do grupo experimental e controle foi de 5:1, resultado estatisticamente significante. Concluiu que, se o processo odontoblástico morre seguindo a morte da polpa ou agressão periférica e são expostos ao meio bucal, estes ficam propensos à invasão pelas bactérias presentes.

Estudando amostras isoladas da microbiota de 57 canais radiculares de dentes permanentes e da cavidade bucal de 45 pacientes, em exame direto pela 
microscopia e por cultura em aerobiose e anaerobiose, durante as fases da terapia endodôntica, CRAWFORD; SHANKLE ${ }^{26}$, em 1961 detectaram que grande número de microrganismos observado, microscopicamente não o é em cultura, e que quase $26 \%$ dos mesmos, positivos em caldo tioglicolato, foram negativos em ágar enriquecido, enquanto apenas uma cultura positiva em ágar enriquecido foi negativa em caldo tioglicolato, a microbiota do canal radicular diminuiu de uma sessão para outra, bem como do início ao final do tratamento. Streptococcus beta hemolíticos e Staphylococcus aureus encontrados na cavidade bucal não estavam presentes nos canais radiculares, cocos e Streptococcus beta não hemolíticos foram os microrganismos mais encontrados na cavidade bucal e canal radicular tanto pela microscopia como pelo crescimento em cultura.

Em 1964, BIRCH; MELVILLE; NEUBERT ${ }^{9}$ enfatizaram que o sucesso de uma técnica para obtenção de amostras bacteriológicas depende da habilidade em se obter amostras sem contaminação por microrganismos das áreas vizinhas, e ainda organismos representativos do sítio selecionado. Alguns fatores fundamentais, como a acessibilidade da área a ser amostrada, contaminação do campo operatório e do instrumental, como também os métodos empregados para a avaliação da lesão, poderiam interferir nos resultados.

SHOVELTON ${ }^{87}$, em 1964, realizou exame microscópico em 97 dentes permanentes necrosados com o intuito de verificar a distribuição de bactérias ao longo dos vários tecidos dentários. Após à descalcificação, os espécimes foram seccionados e distribuídos em três grupos: 56 dentes sofreram uma série de cortes transversais na região cervical, terço médio e região apical da raiz incluindo tecido mole aderido; 15 dentes tiveram cortes transversais seriados da região apical e 
outros 26 elementos cortes longitudinais seriados ao longo do canal radicular. Paralelamente a este estudo, selecionaram sete dentes com vitalidade e exposição pulpar por cárie e cinco dentes que tiveram o canal radicular preparado mecanicamente para realização da terapia endodôntica e foram seccionados transversalmente. Outros dentes com ausência de cárie e polpa normal foram utilizados como controle. Todos os espécimes foram submetidos às colorações pela hematoxilina-eosina e Gram. Bactérias foram observadas na câmara pulpar ou canal radicular de 79 dentes estudados; em 61 dentes bactérias tinham penetrado no interior dos túbulos dentinários do canal radicular. Os dentes com abscesso agudo periapical apresentavam pouco número de organismos em comparação com os dentes que apresentavam inflamação crônica. Nos dentes com vitalidade e exposição por cárie, grande número de organismos foi observado na superfície da polpa e ausência de invasão bacteriana na dentina na região da câmara pulpar e canal radicular. Nos dentes que foram preparados para tratamento endodôntico nenhum organismo foi encontrado no canal radicular, porém bactérias estavam presentes na dentina que não havia sido removida durante o tratamento. No grupo controle não foram detectadas bactérias.

Valendo-se da microscopia óptica, em 1965, KAKEHASHI; STANLEY; FITZGERARD ${ }^{49}$ observaram a importância de microrganismos na etiologia de patologias pulpares em dentes de rato. Quinze animais convencionais e 21 "germ-free" tiveram os molares expostos ao meio bucal por meio de broca carbide $1 / 2$ Após 1 a 42 dias, os ratos foram mortos e o quadrante da maxila onde se realizou a exposição foi removido em bloco, processado e corado pelas técnicas hematoxilina-eosina, tricrômico de Masson e Brown e Brenn. Nos animais convencionais, as amostras obtidas no oitavo dia apresentavam remanescente de 
tecido pulpar vital somente na metade apical das raízes, enquanto a polpa coronária mostrava-se necrótica, purulenta e freqüentemente presença de colônias bacterianas. Após o oitavo dia demonstraram necrose pulpar com tecido inflamado crônico e formação de abscessos na região periapical. Quanto aos animais "germfree" dezoito sobreviveram aos procedimentos operatórios. Estes animais apresentaram os dentes com mínima inflamação pulpar, devido ao ato cirúrgico, porém com vitalidade preservada. Como consequiência do processo inflamatório observou-se reabsorção das raízes. Após 14 dias, verificou-se grande quantidade de matriz dentinária desorganizada e barreira de tecido mineralizado isolando remanescente pulpar do meio bucal. Concluíram que a presença de microrganismos torna-se fator determinante em polpas necróticas expostas ao meio bucal.

A microbiota radicular de dentes decíduos infectados foi examinada empregando-se culturas aeróbia e anaeróbia, em 1967 por MARSH; LARGENT ${ }^{58}$. Para tanto, recolheu-se por meio de pontas de papel estéril, amostras dos canais radiculares de 18 molares decíduos que apresentavam grande lesão de cárie e outros quatro elementos restaurados. Foram isoladas 15 variedades de microrganismos numa média de 2 a 5 espécies por dente. Os mais encontrados foram Streptococcus (alfa, beta e gama) em $82 \%$ dos espécimes, Staphylococcus (albus e aureus) em $32 \%$ e cocos e difteróides anaeróbios em 41\%. A complexa população bacteriana detectada, neste estudo, revela que o tratamento de molares decíduos infectados deve ser direcionado para a redução ou eliminação da microbiota o mais precocemente possível. 
Com propósito de testar "in vitro", a ação de alguns medicamentos comumente empregados no tratamento endodôntico de dentes decíduos, em 1969, BENFATTI; ANDRIONI ${ }^{4}$ utilizaram 40 placas e sobre o ágar simples enriquecido com triptone foram semeados microrganismos removidos de canais radiculares infectados (estreptococos e estafilococos). As drogas testadas foram pastas contendo formocresol (óxido de zinco e formocresol), Ox-para (óxido de zinco e paramonoclorofenol canforado), antibiótico (Frademicina, óxido de zinco e eugenol) e óxido de zinco e eugenol. Pode-se verificar que dentre as pastas testadas, a Ox-para provocou maior halo de inibição diante das bactérias semeadas nas placas, seguidas pelas pastas contendo formocresol e antibiótico que mostravam uma correspondência na inibição ao crescimento bacteriano. Pela interpretação dos resultados, verificou-se que todas as pastas testadas, exceto a pasta de óxido de zinco e eugenol, apresentaram halo maior que 20mm, permitindo afirmar que a mistura bacteriana foi altamente sensível.

Em 1970, HOBSON ${ }^{47}$ desenvolveu estudo cujo objetivo foi verificar as condições microscópicas da polpa e a localização de microrganismos causadores de infecção. Para tanto, foram observados três grupos de dentes decíduos; grupo 1: dentes com ausência de cárie extraídos para fins ortodônticos; grupo 2: dentes com ausência de cárie que esfoliaram normalmente; grupo 3: dentes com lesão de cárie e alterações pulpares. Os elementos após extraídos ou esfoliados foram preparados, seccionados longitudinalmente e corados pela técnica hematoxilina eosina e pela técnica Gram. Dos 93 dentes cariados extraídos, 32 espécimes demonstraram áreas reabsorvidas na parede do canal radicular, 26 apresentavam tecido necrosado na polpa coronária e radicular, em 18 elementos verificou-se a penetração de organismos dentro dos túbulos dentinários na região dos canais 
radiculares superior a metade da espessura dentinária. $\mathrm{Na}$ área do soalho da câmara pulpar houve invasão em 17 casos, com profundidade variada, todavia em duas amostras a penetração estendeu-se ao longo de toda espessura da dentina. Em todos os casos onde se observou a penetração de bactéria dentro dos túbulos, a polpa estava necrosada. A infiltração de organismos dentro dos túbulos na região do soalho da câmara pulpar de molares, sugere que toxinas possam ter acesso à área inter-radicular explicando a típica imagem radiolúcia encontrada em molares decíduos necrosados. A presença de organismos nos túbulos dentinários ou tecido reacional em dentes decíduos é de grande interesse porque, embora em "silêncio clínico" a exposição durante o processo de reabsorção poderia conduzir a uma reinfecção dos tecidos circunvizinhos. No tratamento de dentes decíduos necrosados, ressalta-se a importância do emprego de drogas antibacterianas com capacidade de penetração dentro dos tecidos, na tentativa de controlar a infecção.

Em crianças com idade entre 5 e 12 anos a microbiota dos tecidos aos arredores do dente, dos canais radiculares e do alvéolo de 30 molares decíduos necrosados foram examinados por TOMIC-KAROVIC; JELINEK ${ }^{97}$, em 1971. As amostras da mucosa aos arredores dos dentes e dos canais radiculares foram recolhidos por meio de uma agulha Miller ou ponta de papel estéreis, em seguida os dentes foram extraídos e coletaram-se amostras do alvéolo da região do ápice radicular. Todo material coletado foi inoculado diretamente em ágar sangue, caldo de glucose a $1 \%$ e caldo de tioglicolato. A microbiota encontrada foi muito variada dependendo da área da amostra incluindo organismos potencialmente patogênicos. Streptococcus salivarius foram predominantes nos três tipos de amostras; ao arredor do dente $80 \%$, no canal radicular $76 \%$ e no alvéolo $80 \%$. Nas amostras do canal radicular, os organismos mais encontrados foram: Bacteroides e 
saprófitas 36\%, Lactobacillus 26\%, Streptococcus $\beta$-hemolíticos 23\%, Streptococcus $\alpha$-mitis, Pneumococcus, Staphylococcus albus, Neisseria $20 \%$ e Candida albicans $16 \%$. Puderam concluir que dentes necrosados não devem ser conservados sem o tratamento necessário, com o intuito de preservar espaços para o sucessor permanente, tendo em vista o grande número de organismos patogênicos detectados.

Ao estudar a presença de microrganismos e suas enzimas na cavidade pulpar de 110 molares decíduos humanos cariados, infectados e com ausência de lesão periapical por meio de procedimentos de cultura em condições aeróbias e anaeróbias, EDWARDS; $\mathrm{NORD}^{30}$, em 1972, detectaram em 80 espécimes a presença de microrganismos. Noventa e seis cepas bacterianas diferentes foram isoladas. Os microrganismos mais frequientes foram Streptococcus mitis, seguidos pelos Micrococci, Peptostreptococci, Streptococcus faecalis e Lactobacillus. Cerca de 19\% dos isolados foram anaeróbios. Quanto à presença de enzimas, 30\% dos Streptococcus mitis e algumas Corynebacteria produziram hialuronidase; gelatinase e atividade caseinolítica foram identificadas com Streptococcus faecalis; chitinase e atividade bacteriolítica com Micrococci e desoxyribonuclease com Streptococcus mitis. Foram encontrados microrganismos em $70 \%$ das amostras devido às bactérias penetrarem mais profundamente no soalho das cavidades em dentes decíduos do que em permanentes; a ocorrência de anaeróbios poderia ter sido maior com o emprego de técnica anaeróbia aprimorada e ainda as reações teciduais pulpares e periapicais dependem da associação de microrganismos capazes de elaborar reações tóxicas e imunológicas nos tecidos. 
Em 1974, OLGART; BRÄNNSTRÖM; JOHNSON ${ }^{67}$ desenvolveram trabalho "in vivo" e "in vitro" com o propósito de observar a penetração de bactérias nos túbulos dentinários de pré-molares humanos unirradiculares. Os dentes foram separados em três grupos: dentes que após extraídos tiveram exposição dentinária por fratura intencional da cúspide vestibular e posterior preenchimento do canal com suspensão de Streptococcus; dentes com exposição dentinária por desgaste e dentes com exposição dentinária por desgaste e tratado com ácido cítrico a 50\% por dois minutos. Após o desgaste todas as áreas de dentina expostas foram deixadas sem proteção na cavidade bucal por uma semana. Para análise sob microscopia, os espécimes foram desmineralizados em EDTA e submetidos às colorações pela hematoxilina-eosina e Brown e Brenn. Pode-se verificar intenso crescimento bacteriano em grande número de túbulos dentinários nas áreas subjacentes à dentina fraturada e desmineralizada, ao passo que nos locais de exposição dentinária por desgaste sem tratamento ácido, poucos túbulos apresentavam-se com bactérias e em profundidade discreta. De acordo com os resultados os autores sugerem que bactérias podem penetrar em túbulos dentinários de dentina vital intacta, indiferentemente se os túbulos estão abertos ou recobertos por debris. A superfície dentinária sem proteção por alguns dias e recoberta com placa deverá ser tratada clinicamente como dentina cariada e a camada superficial eliminada na tentativa de se remover as aberturas dos túbulos aumentados pelo preenchimento com bactérias.

WITTGOW; SABISTON ${ }^{103}$, em 1975, estudaram em meio de cultura em aero e anaerobiose a microbiota dos canais radiculares de 40 incisivos permanentes humanos com coroas intactas e polpa necrótica resultante de trauma de 33 pacientes e observaram crescimento bacteriano em 32 amostras. Um total de 
oitenta e duas espécies foram isoladas, com uma média de 2,5 espécies por dente. Os microrganismos anaeróbios comumente isolados foram bacilos Gramnegativos em 27 dentes: Bacteroides, Fusobacterium e Campylobacter sputorum; bacilos Gram-positivos em dez dentes: Eubacterium alactolyticum, Lactobacillus sp, Propionibacterium acnes; cocos Gram-positivos em nove dentes: espécies de Peptostreptococcus e cocos Gram-negativos em quatro dentes: Veillonella parvula. Espécies de Lactobacillus, Actinomyces, Streptococcus e Staphylococcus aureus foram os microrganismos facultativos freqüentemente encontrados. Devido à grande proporção de patógenos isolados, sugere-se precaução durante a etapa de instrumentação endodôntica em dentes com coroas intactas e necrose pulpar com o intuito de evitar que os microrganismos sejam empurrados para o periápice.

Em 1977, GOODMAN ${ }^{41}$ por meio de cultura em aero e anaerobiose, quantificaram a presença de microrganismos do sistema de canais radiculares de dentes permanentes humanos intactos com polpa necrótica. Cinqüenta e cinco culturas positivas foram obtidas dos 55 espécimes selecionados como amostras. Dezoito casos apresentavam, somente bactéria anaeróbia e em 37 amostras observou-se tanto bactéria aeróbia como anaeróbia. Em todos os espécimes isolouse pelo menos uma bactéria anaeróbia enquanto que em um caso isolaram-se mais que quatro anaeróbios. Os mais freqüentes foram: Veillonella sp; Propionibacterium; Peptostreptococcus, Bacteroides sp e Eubacterium sp. Mais da metade dos microrganismos detectados foi anaeróbios e Gram-negativos. Os autores sugerem a eliminação de bactérias anaeróbias do sistema de canal radicular para eliminar as infecções de origem dentária, pois microrganismos foram presentes em todos os casos necróticos deste estudo. 
Objetivando estudar microrganismos remanescentes no canal radicular, túbulos dentinários, cemento ou tecido apical após obturação com diferentes materiais, ROWE, BINNIE ${ }^{79}$, em 1977, realizaram experimentos em cachorros Beagle, empregando microscopia óptica e colorações pela hematoxina-eosina e Brown e Brenn. Polpas de pré-molares inferiores com raízes incompletas foram expostas ao meio bucal sob anestesia geral, 26 canais permaneceram abertos por uma semana, 88 canais foram preenchidos imediatamente, e seis outros permaneceram abertos até o final do experimento (20 semanas). Seguida obturação do conduto todos os casos foram restaurados. Posteriormente a arcada inferior foi removida, o bloco processado e cortes seriados no sentido do plano sagital verificados pela microscopia. Microrganismos puderam ser observados em grande quantidade nos canais e com menos freqüência no interior dos túbulos dentinários, cemento e ligamento periodontal apical, não houve correlação entre o score microbiológico e a severidade da inflamação periapical. Concluíram que o sucesso ou não do tratamento endodôntico está na dependência não só da presença de microrganismo, mas também da metodologia do preparo do canal, sinais e sintomas clínicos e seleção do material obturador.

Para avaliar a relação existente entre as características microscópicas da polpa e a penetração de bactéria em esmalte e dentina nos processos de cárie, em 1979, RAYNER; SOUTHAM ${ }^{75}$ estudaram 66 molares decíduos sem exposição pulpar por cárie. Os dentes após a extração, desmineralização em ácido fórmico a $7 \%$ foram seccionados longitudinalmente e submetidos às colorações pela hematoxilina-eosina e Gram. A espessura média de remanescentes de dentina sadia foi $0,9 \mathrm{~mm}$ para dente com polpa normal comparada com $0,6 \mathrm{~mm}$ em dente com polpa inflamada. A diferença média entre os valores foi estatisticamente 
significante $(\mathrm{p}<0,05)$. Cinqüenta e nove dentes $(89 \%)$ apresentavam dentina reacional. Em 19 elementos $(32 \%)$ as bactérias estavam presentes na dentina tardiamente formada e $84 \%$ apresentaram inflamação pulpar. Isto demonstra que a dentina reacional nem sempre previne os efeitos irritativos da lesão de cárie sobre a polpa. Os resultados enfatizam a necessidade de se prevenir a lesão de cárie em dentes decíduos e providenciar precocemente a restauração do elemento dentário quando necessário, tendo-se em vista a pouca espessura de esmalte e dentina que recobre à polpa de dentes decíduos e ainda à rápida resposta da polpa dos decíduos frente a dentina cariada.

ZAVISTOSKI et $\mathrm{al}^{107}$, em 1980, empregando meio de cultura quantificaram o número de microrganismos em polpas necrosadas de dez dentes humanos permanentes com coroas intactas. Encontraram aproximadamente seis espécies distintas por amostra, com anaeróbios representando dois terços de todos os microrganismos isolados predominando: Bacteroides, Propionibacterium acnes e Veillonella. O número médio de bactérias foi aproximadamente de $10^{7.7}$ unidades formadoras de colônias por grama de tecido amostrado, similar à concentração bacteriana em outros sítios anatômicos na presença da infecção. Os resultados suportam que o canal radicular de dentes com polpa necrótica contém relativamente grande microbiota de bactérias.

Objetivando identificar bactérias associadas com abscesso periapical em crianças, BROOK; STEPHEN; RAYMOND ${ }^{12}$, em 1981, estudaram sobre condições aeróbias e anaeróbias o conteúdo aspirado de abscesso periapical de 12 dentes portadores de necrose pulpar em pacientes com idade entre 5 e 16 anos. Foram isolados anaeróbios em todos os espécimes; em oito pacientes (67\%) 
encontraram somente anaeróbio e em quatro pacientes (33\%) estavam junto com aeróbios. Entre os anaeróbios puderam detectar 20 espécies de Bacteroides (incluindo nove $B$ - melaminogenicus, três $B$ - oralis e três $B$ - corrodens); 17 cocos Gram-positivos anaeróbios; cinco espécies de Fusobacterium e sete bacilos Gram-positivos (incluindo três espécies de Actinomyces e três espécies de Lactobacillus). Quanto as espécies bacterianas aeróbias isoladas detectaram três Streptococcus salivarius, dois Streptococcus alfa hemolíticos e um gama hemolítico. Os autores encontraram que os organismos anaeróbios têm papel fundamental na etiologia polimicrobiana de abscessos periapicais em crianças.

Em 1981, MÖLLER et $\mathrm{al}^{60}$ estudaram em macacos a relação entre a presença de bactérias do tecido pulpar na indução da inflamação periapical em 78 dentes permanentes que tiveram suas polpas assepticamente necrosadas. Vinte e seis dentes foram selados e permaneceram livres de microrganismos por 6 a 7 meses e os 52 espécimes restantes foram mantidos expostos à microbiota indígena bucal por 6 a 7 dias e posteriormente, ficaram selados até o final do experimento (6 - 7 meses). Os autores observaram por meio dos exames clínicos, radiográfico, microbiológico e microscópico que os canais não infectados apresentaram-se estéreis até o final do experimento, detectando-se na maioria dos casos, ausência ou discreta inflamação dos tecidos periapicais. Os dentes com polpas contaminadas desenvolveram periodontites apicais e os canais apresentavam anaeróbios facultativos como: Streptococcus $\alpha$ - hemolíticos e Enterococcus; anaeróbios estritos: Bacteroides, Eubacterium, Propionibacterium, Peptococcus e Peptostreptococcus e ainda bactérias da microbiota indígena bucal. Concluíram, que o número de microrganismos com capacidade para sobreviver em canal radicular fechado foi substancialmente reduzido durante o período experimental. 
Com o propósito de observar o crescimento bacteriano nas paredes da dentina pulpar e nos túbulos dentinários, em 1982, AKPATA; BLECHMAN ${ }^{1}$ selecionaram 14 dentes permanentes unirradiculares com polpas vitais extraídos por razões periodontais e protéticas. Os canais radiculares foram instrumentados, irrigados com soro fisiológico e esterilizados em gás de óxido de etileno. A seguir foram inoculados com anaeróbios estritos: Bacteroides melaninogenicus e Peptococcus assacharolyticus, e facultativos: Streptococcus faecalis e Streptococcus sanguis. Após 1 a 3 semanas de incubação, os espécimes tiveram coroa e ápice eliminados e o remanescente radicular foi dividido em três terços: cervical, médio e apical. As peças foram processadas, submetidas à coloração de Brown e Brenn e analisadas sob microscopia óptica. A extensão da invasão bacteriana na dentina radicular foi proporcional ao período de incubação. Poucos túbulos dentinários do terço cervical da raiz haviam sido envolvidos por $S$. sanguis após uma semana de incubação. Nos dentes incubados por duas semanas já era marcante a presença de bactérias nos túbulos dentinários dos terços cervical e médio, enquanto que somente no final da terceira semana, a superfície dentinária radicular interna apresentou colônias bacterianas aderidas em toda sua extensão. Streptococcus faecalis penetraram mais em túbulos dentinários após três semanas de incubação, Bacteroides melaninogenicus marcaram pouca presença, provavelmente devido ao crescimento lento. As secções transversais do terço apical da raiz foram as menos envolvidas por bactérias. Os autores concluíram que a extensão da invasão bacteriana na parede da dentina pulpar foi proporcional ao período de incubação e à taxa de multiplicação dos microrganismos. Onde houve grande crescimento bacteriano, os túbulos dentinários radiculares também foram invadidos por microrganismos. 
Utilizando-se da microscopia de contraste de fase, meios de cultura e colorações de Gram e Giemsa, em 1982, FABRICIUS et $\mathrm{al}^{31}$ realizaram experimentos com o intuito de observar a distribuição de diferentes espécies microbianas no canal radicular, de 24 dentes permanentes unirradiculares de três macacos. As polpas dos dentes da amostra foram expostas à microbiota bucal e após uma semana as áreas de acessos foram seladas. Amostras do conteúdo do canal radicular de 16 dentes provenientes de dois macacos foram coletados após 7, 90, 180 e 1060 dias. No final do período experimental em todos os dentes, observaram-se radiograficamente alterações patológicas. Os autores evidenciaram que nas amostras iniciais a relação de cepas de anaeróbios estritos para facultativos, dos animais de 90 e 180 dias, foi de 1.7 e 1.4, respectivamente. Nesses mesmos animais, ao final dos 90 e 180 dias a relação foi de 3.9 e 6.5 respectivamente; nos animais de 1060 dias essa mesma relação foi de 11.3 e em alguns casos não se observaram microrganismos facultativos nas amostras finais. Bacteróides e os bacilos Gram-positivos anaeróbios foram encontrados em quase todas as amostras iniciais e finais. A porcentagem de bactérias anaeróbias estritas nas amostras iniciais dos grupos de 90 e 180 dias, foi respectivamente, de $50 \%$ e $55 \%$, enquanto nas amostras finais, os anaeróbios estritos representaram $85 \%$ a 98\% da microbiota. Nas amostras iniciais, os principais grupos bacterianos se faziam presentes em significantes proporções, com exceção de cocos Gramnegativos, e nas amostras finais, predominavam os bacilos anaeróbios estritos Gram-positivos e Gram-negativos. Nas diversas partes do sistema de canal radicular, observou-se diferença entre os achados bacterianos, detectando grande aumento de bactéria anaeróbia estrita como Bacteroides de crescimento lento, incluindo alguns bacilos Gram-positivos anaeróbios, sugerindo seu relevante papel no desenvolvimento e manutenção da periodontite apical. 
BYSTRÖM; SUNDQVIST ${ }^{16}$, em 1983, compararam a eficácia antimicrobiana do hipoclorito de sódio a $0,5 \%$ e solução de soro fisiológico na irrigação do canal radicular de 30 dentes permanentes unirradiculares de humanos portadores de necrose pulpar, com a parede da câmara pulpar intacta e rarefações ósseas periapicais. Quinze elementos foram irrigados com solução salina enquanto os demais foram irrigados com o hipoclorito de sódio a $0,5 \%$. No início da pesquisa, todos os canais apresentaram culturas positivas de microrganismos, sendo isolados 169 diferentes espécies bacterianas. A maioria das culturas permitiu crescimento de mais de uma espécie, sendo que $88 \%$ dos isolados eram anaeróbios. Os mais comumente detectados foram Fusobacterium nucleatum, Eubacterium alactolyticum, Peptostreptococcus micros, Bacteroides melaninogenicus e oralis e Eubacterium lentum. As soluções irrigadoras foram utilizadas durante a instrumentação em cinco sessões com intervalos de 2 a 4 dias e a presença de bactérias no canal foi verificada em cada ocasião. Não houve emprego de curativo intracanal entre as sessões. Os testes bacteriológicos realizados demonstraram culturas negativas em 12 e 8 espécimes tratados, respectivamente, com hipoclorito de sódio a 0,5\% e soro fisiológico. A partir dos resultados, pode-se concluir melhor efetividade da solução de hipoclorito de sódio a $0,5 \%$ como irrigante de canais em comparação ao soro fisiológico.

Por meio da microscopia de campo escuro, em 1986, THILO; BAEHNI; HOLZ ${ }^{95}$ observaram a distribuição de bactérias nos terços coronário e apical dos canais radiculares de dentes permanentes humanos com polpa necrótica. Vinte dentes unirradiculares após extração foram seccionados em duas partes iguais e o conteúdo bacteriano dos terços coronário e apical dos canais foram para análise microscópica revelando que 16 dos 20 elementos examinados apresentavam 
bactérias ao longo de todo canal radicular. A porcentagem de cocos e bacilos foi significantemente maior no terço coronário e a porcentagem de microrganismos filamentosos e espiroquetas foi ligeiramente maior no terço apical, mas sem diferença estatística significante. Houve correlação positiva entre a porcentagem de espiroquetas encontradas no terço apical dos canais e o tamanho das lesões periapicais detectadas radiograficamente.

BYSTRÖM et $\mathrm{al}^{17}$, em 1987, por meio de técnicas bacteriológicas e microscopia óptica, analisaram a eficácia do tratamento endodôntico realizado em 79 dentes humanos unirradiculares com polpa infectada e portadores de lesões periapicais. O preparo biomecânico dos canais radiculares foi auxiliado por soluções químicas irrigadoras e o hidróxido de cálcio foi empregado como curativo intracanal entre as sessões. Os canais foram obturados somente após os testes bacteriológicos apresentarem-se negativos. A conduta sobre as lesões periapicais dos dentes tratados foi proservá-las por um período de 2 a 5 anos. Pôde-se verificar que 67 lesões repararam, todavia, em sete casos, a lesão regrediu, mas não totalmente no prazo de dois anos e ainda detectou-se persistência do processo infeccioso em cinco casos. Estes dentes onde houve persistência do quadro infeccioso foram submetidos à cirurgia apical e os espécimes processados para análise microscópica. Espécies bacterianas como Actinomyces israelli, Actinomyces naeslundii e Arachia propiônica foram identificadas por meio da imunocitoquímica. Os resultados sugerem que a persistência de lesões periapicais após terapia endodôntica pode estar relacionada com a presença de bactérias remanescentes no canal dentinário, nos túbulos dentinários expostos à superfície radicular, nas lacunas do cemento celular, nas 
foraminas apicais e em raspas de dentina e/ou cemento contaminados, lançados para a região periapical durante o preparo biomecânico.

Em 1987, HAAPASALO; ORSTAVIK ${ }^{43}$ desenvolveram "in vitro" um modelo para infecção de túbulos dentinários com o intuito de verificar a eficácia de medicamentos utilizados como curativo intracanal. Os espécimes constituíramse de blocos de dentina com formato cilíndrico obtidos a partir de incisivos intactos de bovinos recém-extraídos. O preparo constituiu-se na remoção do cemento e da "smear layer" permitindo a abertura dos túbulos dentinários por meio de ultra-som, EDTA a $17 \%$ e hipoclorito de sódio a 5,25\%. A seguir, os espécimes foram infectados por Enterococcus faecalis em meio apropriado e analisados pela microscopia eletrônica de varredura e pela microscopia óptica após coloração pela Brown e Brenn. Nos espécimes infectados com E. faecalis somente por um dia, as bactérias estavam no interior dos túbulos dentinários a 300-400 $\mu \mathrm{m}$ de profundidade, a partir do lume do canal. Após três semanas de incubação, uma densa infecção apresentando 300-400 $\mu \mathrm{m}$ de profundidade; uma infecção moderada atingiu 400-500 $\mathrm{m}$ e a linha de frente da infecção estendia-se a 800-1000 $\mu \mathrm{m}$ de profundidade. Em relação à eficácia medicamentosa do paramonoclorofenol canforado e do hidróxido de cálcio (Calasept), pôde-se verificar que o PMCC promoveu a completa desinfecção dos túbulos dentinários em uma hora na forma líquida e em um dia quando gasoso, todavia, o $\mathrm{Ca}(\mathrm{OH}) 2$ não se demonstrou eficaz na eliminação de bactérias nas áreas mais internas de dentina mesmo após prolongada incubação. Segundo os autores, o modelo desenvolvido parece adequado para testes "in vitro" de medicamentos de canais radiculares. 
Em 1987, NAIR ${ }^{64}$, por meio da microscopia óptica e eletrônica de transmissão analisou dentes permanentes humanos com cárie profunda portadores de necrose pulpar e lesões periapicais. Dos 31 espécimes selecionados, 26 apresentavam-se assintomáticos e cinco dentes eram sintomáticos. A microscopia óptica revelou presença de bactérias no interior dos canais radiculares de todos os dentes, constituindo uma microbiota mista, composta por cocos, bacilos, formas filamentosas e espiroquetas. Na microscopia eletrônica, pode-se observar algumas bactérias densamente agregadas em meio a um material amorfo, aderidas às paredes dentinárias do canal, todavia a maioria da microbiota bacteriana permanecia livre entre o vasto número de polimorfonucleares no conteúdo aquoso do canal radicular. Em alguns espécimes, a dentina radicular revelou grupos isolados de bactérias se desagregando e ampliando os túbulos dentinários.

Utilizando ratos como modelo experimental, em 1987, PATERSON; WATTS $^{69}$, estudaram por meio da microscopia óptica, as polpas dentárias expostas ao meio bucal em animais albinos "germ-free" e convencionais com a finalidade de identificar fatores etiopatogênicos das doenças pulpo-periapicais. Inicialmente as polpas dos molares superiores foram expostas ao meio bucal por um período de 15 minutos, 1, 2, 3, 7, 8 e 28 dias para os animais "germ-free" e 1, 2 e 7 dias para os convencionais. A seguir, os animais foram mortos e seus maxilares processados para exame por meio da microscopia óptica após colorações pela hematoxina-eosina e pelo método Gram para demonstrar a presença e distribuição das bactérias. Em animais "germ-free" em intervalos de tempo até sete dias, a resposta inflamatória limitou-se à presença de esparsas células inflamatórias localizadas sob os debris da superfície lesada. Em intervalos mais longos, houve alta incidência de formação de barreira de tecido mineralizado 
sobre o remanescente pulpar, mas, em alguns espécimes a polpa apresentava-se necrosada, provavelmente em conseqüência da impactação alimentar. Nos animais convencionais a partir do segundo dia após a exposição, pôde-se observar desde intenso infiltrado inflamatório até necrose pulpar incluindo penetração de bactérias nos túbulos dentinários. Os autores concluíram que as bactérias desempenham um papel fundamental na etiopatogenia das doenças pulpo-periapicais. Trauma mecânico isolado não resultou em processo inflamatório significante do tecido pulpar.

Por meio de métodos adequados de cultura em condições anaeróbias e aeróbias, em 1987, YOSHIDA et al $^{106}$ estudaram as correlações entre sintomas clínicos de lesões periapicais e a distribuição de bactérias isoladas dos canais radiculares de dentes permanentes com polpas necrosadas. Os pacientes foram divididos em três grupos baseados na combinação dos sintomas: grupo 1 - dor espontânea, dor a percussão e exsudação; grupo 2 - dor a percussão mas não espontânea; grupo 3 - dor a percussão e não espontânea e exsudação. Os autores encontraram no grupo 1: predomínio de anaeróbios, cerca de $79 \%$ dos isolados, entre eles: Eubacterium, Bacteroides e espécies de Peptostreptococcus e Peptococcus magnus; no grupo 2: anaeróbios como Peptococcus magnus, Peptostreptococcus, Eubacterium, Actinomyces e espécies de Bacteroides; grupo 3: as bactérias facultativas foram predominantes entre elas: Streptococci oral. Pôde-se concluir que o crescimento de espécies bacterianas principalmente anaeróbias nos canais radiculares com polpa necrótica relacionam-se com a presença de sintomas clínicos. As espécies patogênicas como B. melaninogenicus e P. magnus podem apresentar um papel fundamental. 
O conteúdo do canal radicular de nove molares decíduos humanos com lesão periapical, foi analisado bacteriologicamente utilizando-se cultura em condições anaeróbias por TOYOSHIMA et $\mathrm{al}^{98}$, em 1988. Os resultados permitiram observar a presença de bactérias em sete espécimes. Em quatro casos detectou-se radiograficamente o deslocamento do germe do dente permanente, nestes, o número de bactérias isoladas foi maior, ou seja, $\left(1,7 \times 10^{5}\right.$ unidades formadoras de colônias por $\mathrm{ml}-3,7 \times 10^{6}$ unidades formadoras de colônias por ml) comparando-se com os demais casos $\left(1,8 \times 10^{2}\right.$ unidades formadoras de colônias por $\mathrm{ml}-4,2 \times 10^{3}$ unidades formadoras de colônias por $\mathrm{ml}$ ). Houve predomínio de anaeróbios estritos, bacilos Gram-negativos e Gram-positivos e cocos Grampositivos; os espécimes mais freqüentes foram: Bacteroides, Fusobacterium, Peptostreptococcus, Streptococcus anaeróbios, Eubacterium e Streptococcus facultativos. Nos espécimes onde houve o deslocamento do germe do permanente, Bacteroides, Peptostreptococcus e Eubacterium foram dominantes. Os autores concluíram que anaeróbios como Bacteroides, Peptostreptococcus e Eubacterium, assim como em lesões periapicais de adultos, podem exibir um papel fundamental na progressão das lesões periapicais em dentes decíduos.

A prevalência de Bacteroides negros e sua correlação com formação de abcessos apicais em 72 dentes permanentes unirradiculares portadores de necrose pulpar e periodontite apical foi estudada em 1989, por SUNDQVIST; JOHANSSON; SJÖGREN ${ }^{91}$. Os resultados obtidos por meio de cultura em anaerobiose do conteúdo dos canais radiculares evidenciaram que todos os canais apresentavam bactérias e cerca de $90 \%$ do total das espécies isoladas eram anaeróbias. As espécies mais encontradas foram Fusobacterium nucleatum, Bacteroides intermedius, Peptostreptococcus micros, P. anaerobius, Eubacterium 
lentum, E. alactolyticum. Em 22 canais radiculares pôde-se detectar Bacteroides negros. As infecções foram polimicrobianas e assim como o número médio de cepas bacterianas, o número de células bacterianas foi mais marcante nos canais com culturas positivas de Bacteroides negros. A presença de abscessos apicais pode ser induzida por combinações específicas de bactérias radiculares e a presença de Bacteroides endodontales, $B$. gingivalis, ou $B$. intermedius faz-se essencial. Enfatizaram que os métodos de instrumentação dos canais radiculares também é determinante no desenvolvimento de abscessos pós-tratamento quando o canal apresenta espécies de Bacteroides negros, pois as bactérias são lançadas para o periápice durante a biomecânica.

A capacidade de algumas bactérias comumente detectadas em canais radiculares infectados em induzir inflamação, foi estudada por WU et $\mathrm{al}^{105}$, em 1989 por intermédio de meio de cultura e análise pela microscopia de contraste de fase. Nove espécies de bactérias bucais (Bacteroides endodontalis e intermedius, Fusobacterium nucleatum, Peptostreptococcus anaerobius, Eubacterium lentum, Actinomyces viscosis, Streptococcus mutans e mitior e Lactobacillus fermentum) foram combinadas em quatro grupos distintos e inoculadas no interior de 144 tubos de polietileno apresentando um orifício (forame) simulando um canal radicular infectado. Quatro tubos foram implantados subcutaneamente em cada um dos 36 ratos selecionados para o experimento por um período de 2 a 4 semanas. Bacteroides, Streptococcus, Actinomyces e Fusobacterium inoculados em pequeno número foram dominantes na microbiota mista no final do experimento. A microbiota mista inoculada nos tubos modificou-se prevalecendo os microorganismos anaeróbios; quantitativamente o número total de bactérias diminuiu durante as primeiras duas semanas “ in vivo”, estabilizando depois; após 
quatro semanas de implantação o grupo que apresentava anaeróbios pareceu causar inflamação mais severa nos tecidos aos arredores do implante em comparação com o grupo de microbiota facultativa. Segundo os autores os tubos implantados demonstravam um sistema adequado para estudar o potencial inflamatório da microbiota patogênica simulando o canal radicular infectado.

Com o objetivo de estudar em humanos a presença e tipos de bactérias que invadem as camadas profundas de dentina infectada da parede do canal radicular, em 1990, ANDO; HOSHINO ${ }^{3}$ colheram amostras de dentina de oito dentes permanentes com canal radicular infectado localizadas a uma profundidade de 0,5 a $0,2 \mathrm{~mm}$ do canal principal e por métodos adequados de aero e anaerobiose evidenciaram maior número de bactérias após incubação em anaerobiose. Das 256 bactérias isoladas, $205(80 \%)$ foram anaeróbios estritos, enquanto que 50 dos isolados $(20 \%)$ foram bactérias facultativas e $1(0,4 \%)$ foi perdido antes de ser examinado. Os anaeróbios estritos predominantemente isolados foram cocos e bacilos Gram-positivos: Lactobacillus (20\%), Streptococcus (13\%), Propionibacterium (9\%) e Peptostreptococcus (5\%), enquanto que bacilos Gramnegativos foram raramente detectados. Os autores puderam concluir que anaeróbios estritos foram freqüentes nas camadas profundas da dentina infectada da parede do canal radicular, indicando que este ambiente favorece crescimento de anaeróbios. A microbiota dessa região é similar àquela das camadas profundas da lesão de cárie na dentina coronária.

Por meio do exame bacteriológico e posterior microscopia eletrônica de varredura, FUKUSHIMA et $\mathrm{al}^{33}$, em 1990, estudaram o ápice radicular de 21 dentes permanentes humanos portadores de tratamento endodôntico e lesão 
periapical assintomática. Após a extração, os espécimes foram incubados em aero e anaerobiose. Diferentes espécies de bactérias foram isoladas, em mais de $60 \%$ da amostra, ou seja, 13 dentes demonstraram culturas positivas, com predomínio de bactérias anaeróbias, entre elas: Bacteroides, Eubacterium, Peptostretococcus e Peptococcus. A microscopia revelou massas de bactérias entre o material obturador e o limite superior do forame apical, todavia não se detectou bactéria na área do forame apical ou na superfície externa da raiz.

A respeito das possíveis correlações existentes entre as microbiotas dos canais radiculares e de bolsas periodontais profundas, após revisão de literatura, KEREKES; OLSEN ${ }^{50}$, em 1990, enfatizaram que existem similaridades entre as microbiotas do canal radicular e bolsa periodontal de dentes intactos sem lesões periapicais, indicando a possibilidade de ocorrerem infecções cruzadas entre ambos. Considerando a grande diversidade de microrganismos colonizadores de bolsas periodontais versus aqueles isolados de polpas necróticas de dentes com coroas intactas, o número de espécies participante destas infecções cruzadas deve ser limitado. Estes incluem anaeróbios como: Bacteroides, Fusobacterium, Eubacterium, Spirochetes, Wolinella, Selenemonas e Peptostretococcus. De acordo com os autores, a infecção crônica do canal radicular ou ligamento periodontal pode representar um suprimento persistente de bactérias para a circulação sangüínea, assim deve-se tomar cuidado para se prevenir a disseminação para áreas não infectadas do dente, como também para outras regiões do corpo humano.

Valendo-se da microscopia óptica e eletrônica, em 1990, NAIR et al ${ }^{65}$ verificaram a presença de bactérias na porção apical da raiz e periápice de nove 
dentes permanentes tratados endodonticamente e portadores de lesões periapicais persistentes por um período de 4 a 10 anos. As amostras foram obtidas cirurgicamente de pacientes adultos e processadas para a análise microscópica. Microrganismos puderam ser identificados em seis dos nove elementos estudados; quatro revelavam bactérias e dois presença de fungos. A microscopia óptica pôde mostrar claramente bactérias em um dos espécimes; e nos outros três espécimes houve necessidade de cortes seriados para observá-los à microscopia eletrônica. As bactérias encontravam-se agregadas ou isoladas, livres ou aderidas à parede dentinária do canal principal, canal acessório e delta apical. Na microscopia eletrônica ainda pôde-se verificar cocos, bacilos e espiroquetas Gram-positivos dispostos em densas colônias, localizadas nas lacunas de Howship da parede interna do canal. Segundo os autores, as lesões persistentes após terapia endodôntica podem estar relacionadas a fatores que possibilitam a viabilidade de microrganismos residuais no canal radicular após o tratamento.

O efeito antimicrobiano do hidróxido de cálcio e solução de iodo iodetado sobre túbulos dentinários infectados foi estudado "in vitro" em 1990, por SAFAVI; SPANGBERG; LANGELAND ${ }^{80}$, em raízes de dentes permanentes humanos intactos. Todos os dentes tiveram a coroa e cemento removidos, posteriormente os canais foram ampliados com limas três números acima da largura original do lume do canal, tratados com solução de hipoclorito de sódio a $5,25 \%$ e ácido cítrico a 50\%. A seguir inoculadas com Streptococcus faecalis em meio apropriado. De acordo com o período de incubação os espécimes foram separados em grupo infectado e grupo contaminado, respectivamente, para um período de 72 horas e alguns segundos de incubação. Os espécimes que não foram incubados com os microrganismos foi o grupo controle. No final do período 
predeterminado, os espécimes foram examinados pela microscopia óptica após preparo e coloração pela técnica de Brown e Brenn. Pôde-se constatar que os microrganismos estavam presentes somente nos túbulos dentinários do grupo infectado. A infecção dos túbulos ocorreu geralmente no lado pulpar da dentina, principalmente nas áreas onde o cemento correspondente tinha sido removido. A penetração de microrganismos, foi aproximadamente entre 50 a $100 \mu \mathrm{m}$ de profundidade, chegando até a $300 \mu \mathrm{m}$ em alguns cortes. Nenhum microrganismo foi observado penetrando em cemento. Quanto aos espécimes tratados com solução de iodo iodetado, um curto período de contato da dentina com o medicamento foi suficiente para prevenir o crescimento microbiano, todavia em espécimes tratados com hidróxido de cálcio, culturas positivas foram freqüientemente observadas mesmo após longos períodos de contato.

TRONSTAD; BARNETT; CERVONE ${ }^{99}$, em 1990, verificaram a presença de microrganismos na superfície apical radicular removida durante tratamento cirúrgico de dez dentes permanentes portadores de lesões periapicais persistentes após tratamento endodôntico convencional. Culturas em aero e anerobiose do material coletado do interior das lesões periapicais puderam detectar predomínio de bactérias anaeróbias. A análise sob microscopia eletrônica de varredura demonstrou microrganismos, localizados nas áreas irregulares da superfície radicular de todos os espécimes estudados, ora agregados, ora dispostos em colônias em meio a um material extracelular. Cocos e bacilos foram predominantes, todavia formas filamentosas ou fibrilares também foram encontradas. De acordo com os autores estes organismos são provenientes do canal radicular, todavia não descartam a hipótese de difusão pela via hematogênica. 
Na microscopia eletrônica de varredura TRONSTAD; KRESHTOOL; BARNETT $^{100}$, em 1990, observaram a presença de microrganismos na superfície apical de um dente permanente humano unirradicular portador de lesão periapical crônica, persistente ao tratamento endodôntico convencional. Neste estudo, a lesão regredia apenas parcialmente com tratamento antimicrobiano local e sistêmico demonstrando que a microbiota bacteriana poderia ser influenciada, mas não eliminada. $\mathrm{O}$ exame microscópico confirmou a presença de colônias bacterianas constituídas de cocos firmemente aderidos à superfície apical por um material extracelular, provavelmente polissacarídeo, que fornecia nutrição e abrigo às influências externas, contribuindo para a manutenção do processo infeccioso. Após a realização da apicectomia e remoção da lesão periapical a área foi reparada com formação óssea na cavidade cirúrgica após seis meses.

A composição microbiana dos canais radiculares de 19 dentes permanentes humanos infectados foi examinada em 1991, por HIRAI et al ${ }^{46}$ empregando procedimentos de cultura em condições anaeróbias. Quatorze dos 19 espécimes apresentaram cultura anaeróbia com mais de duas espécies de microrganismos. Actinomyces, Prevotella e Propionibacterium foram predominantes, seguidos por Bacteroides, Mitsuokella, Megamonas, Anaerorhabudus, Fusobacterium, Actinobacillus, Capnocytophaga e Eikenella. Cocos Gram-positivos como Streptococcus e Peptostreptococcus também foram isolados. Os resultados indicam que os canais radiculares de dentes desvitalizados apresentam infecção mista com anaeróbios e anaeróbios facultativos.

Em 1991, LIN et al ${ }^{53}$ estudaram por meio dos exames clínico, radiográfico e microscópico 150 casos de insucessos de tratamento endodôntico 
acompanhados por um período médio de 6 meses a 14 anos. As amostras foram obtidas cirurgicamente removendo-se cerca de $3 \mathrm{~mm}$ do ápice radicular dos dentes incluindo o tecido periapical firmemente aderido. Os espécimes foram processados para serem corados pela hematoxilina-eosina e Brown e Brenn. As análises radiográfica e clínica permitiram observar que não houve correlação entre o tamanho da rarefação periapical e a ocorrência ou severidade dos sinais ou sintomas clínicos. Pode-se notar quantidades variáveis de debris no interior dos canais constituídos por raspas de dentina, partículas do cimento obturador e tecido inflamado ou necrótico; células inflamatórias agudas e crônicas estavam presentes na área periapical; reabsorção do ápice radicular estava freqüentemente associada com inflamação periapical severa; bactérias estavam presentes em grande quantidade nos canais e ocasionalmente na área periapical dispostas em maciças ou discretas colônias associadas com restos necróticos no interior do canal e ocasionalmente na área periapical; edema, dor ou fístula foram associados com a presença de bactéria no canal e ocasionalmente nos tecidos periapicais. Concluíuse que a maioria dos insucessos dos tratamentos endodônticos podem estar associados à infecção microbiana.

Em 1992, GENCOGLU; KÜLEKÇI ${ }^{34}$ avaliaram o efeito bactericida dos medicamentos intracanais à base de hidróxido de cálcio (Calacept), paramonoclorofenol canforado (CPCP), Cresofene e iodeto de potássio 2\% (IKI) sobre quatro microrganismos anaeróbios estritos comumente encontrados no canal radicular Streptococcus mutans, Peptostreptococcus anaerobius, Porphyromonas gingivalis e Fusobacterium nucleatum. Inicialmente as pontas de papel estéreis foram inoculadas com o microrganismo e em seguida submersas na solução medicamentosa por 10 a 15 minutos. A formação de colônias entre os organismos 
testados, foi confirmada pela coloração de Gram. Streptococcus mutans, Peptostreptococcus anaerobius, Porphyromonas gingivalis e Fusobacterium nucleatum foram todos destruídos por Calacept, CPCP e Cresofene após 10 e 15 minutos. Todavia IKI a $2 \%$ foi efetiva somente contra $P$. gingivalis $e F$. nucleatum. As pontas de papel controle que foram depositadas em frascos contendo tioglicolato após contaminação na cultura bacteriana produziram crescimento positivo e as pontas controle não contaminadas depositadas diretamente em contato com tioglicolato não produziram crescimento. Durante e após instrumentação, os medicamentos intracanais podem ser eficazes sobre os microrganismos residuais sobreviventes influenciando no prognóstico da terapia endodôntica.

SUNDQVIST $^{89}$, em 1992, realizou estudo bacteriológico empregando meios de cultura em condições aeróbias e anaeróbias para examinar a microbiota dos canais radiculares de 65 dentes permanentes unirradiculares humanos necrosados com paredes da câmara pulpar intacta e reabsorção óssea periapical. Bactérias estavam presentes em todos os canais radiculares com predomínio de anaeróbias em mais de $90 \%$ das amostras. Um total de 353 cepas bacterianas foram isoladas, com uma média de 5,4 por canal. As espécies freqüentemente isoladas foram Fusobacterium nucleatum, Prevotella intermedia, Peptostreptococcus micros, Peptostreptococcus anaerobius, Eubacterium alactolyticum, Eubacterium lentum e Wolinella recta. Diferentes espécies bacterianas se associaram constituindo uma cadeia alimentar, na qual o metabolismo de algumas espécies proporcionaria nutrientes para o crescimento de outras. Os resultados confirmam a presença de uma microbiota característica nos canais radiculares. Durante a infecção, desenvolvem-se fortes interações entre 
diferentes espécies microbianas resultando em mudanças ambientais na microbiota.

A persistência de bactérias no canal radicular pode resultar no fracasso do tratamento endodôntico. Em 1993, PEREZ et al ${ }^{70}$ realizaram estudo "in vitro", com o objetivo de verificar a penetração de bactérias nos túbulos dentinários radiculares de nove incisivos bovinos. Os dentes foram separados em dois grupos de acordo com o grau de maturação apical da raiz. A coroa e o ápice foram eliminados e o restante da raiz dividido em quatro partes. Trinta e seis blocos de dentina foram inoculados em condições anaeróbias e incubados em tubos contendo suspensão de Streptococcus sanguis por um período de 10, 20 e 28 dias, respectivamente, para cada grupo de 12 espécimes. A penetração bacteriana nos túbulos dentinários foi observada por meio da microscopia eletrônica de varredura e microscopia óptica após coloração por Brown e Brenn. Os resultados demonstraram que a penetração nos túbulos por $S$. sanguis variou de $150 \mu \mathrm{m}$ a $792 \mu \mathrm{m}$, sendo que a média de penetração foi de $483 \mu \mathrm{m}$ para o grupo de dentes com ápice imaturo enquanto no grupo de dentes com ápice maduro foi de aproximadamente $430 \mu \mathrm{m}$. O período de incubação de 10 para 28 dias aumentou extremamente o grau de penetração. Estas observações revelam a influência da duração e maturação sobre o grau de penetração bacteriana.

Em 1993, SATO et al $^{83}$ verificaram "in vitro" o efeito da mistura de drogas antibacterianas contra bactérias de lesões de cárie e do tecido pulpar infectado. Quatorze amostras de dentina cariada e 14 amostras de tecido pulpar infectado de dentes decíduos recém-extraídos de crianças entre 3 e 11 anos de idade foram depositadas em placas controle e placas contendo uma mistura de 
medicamentos. As drogas antibacterianas empregadas foram ciprofloxacina e metronidazol associadas a um terceiro antibiótico: amoxicilina, cefaclor, cefroxadina, fosfomicina ou ainda rokitamicina. Nenhuma bactéria foi encontrada frente a combinação das drogas, enquanto o grupo controle apresentou $10^{1}$ a $10^{7}$ unidades formadoras de colônias (CFUs). Nas amostras que foram recobertas com cimento de fosfato $\alpha$-tricalcium contendo a mistura de ciprofloxacina, metronidazol e cefaclor ( $1 \%$ de cada) nenhuma bactéria foi observada, assim como, nas amostras que foram imersas na solução da mistura de $200 \mu \mathrm{g}$ de cada substância. Sugeriu-se que a combinação dos medicamentos pode ser adotada no tratamento endodôntico de dentes decíduos, tendo em vista os resultados obtidos na pesquisa.

Com o objetivo de avaliar a presença e localização de bactérias nos canais radiculares e lesões periapicais crônicas, foram examinados pela microscopia óptica e imunofluorescência 17 dentes permanentes humanos com necrose pulpar e lesões periapicais crônicas por BOHÓRQUEZ AVILA ${ }^{10}$, em 1994. Após preparo prévio, as amostras foram coradas pela Brown e Brenn para visualização de bactérias Gram-positivas e negativas e a técnica de imunofluorescência indireta para observação da Prevotella intermedia. Detectouse alta incidência de bactérias nos canais radiculares, com predomínio de cocos e bacilos Gram-positivos e Gram-negativos, distribuídos ao longo do lume do canal, isoladamente ou em colônias, livres ou aderidos às paredes de dentina e no interior dos túbulos dentinários. Nas lesões periapicais com graus de infecção leve e moderada, as bactérias apresentavam-se em pequenas quantidades, ora isoladas, ora formando colônias com predomínio de bacilos e cocos Gram-positivos 
localizadas entre o ápice e a lesão periapical preferencialmente, nas imediações do forame apical.

DRAKE et $\mathrm{al}^{29}$, em 1994, investigaram "in vitro" os efeitos da smear layer sobre a colonização bacteriana de canais radiculares empregando como modelo experimental 26 caninos permanentes humanos recém-extraídos. Os canais dos dentes foram irrigados com solução de hipoclorito de sódio a 2,5\% durante a instrumentação até a lima 80. Os dentes foram divididos em dois grupos baseados na substância de limpeza final 1-20ml de solução salina estéril ou 2$10 \mathrm{ml}$ de EDTA a $17 \%$ seguida por $10 \mathrm{ml}$ de hipoclorito de sódio a 2,5\% para manutenção ou remoção da smear layer; respectivamente. Os dentes foram inoculados em cultura de Streptococcus anginosus (milleri) $10^{6}$ unidades formadoras de colônias (CFUs). Após o período de duas horas de incubação os espécimes foram processados para análise microbiológica, revelando uma diferença no número de colonização bacteriana $(\mathrm{P}=0,0002)$ entre os dentes com smear layer $\left(10^{4}\right.$ unidades formadoras de colônias) e dentes sem smear layer $\left(10^{5}\right.$ unidades formadoras de colônias). A microscopia eletrônica de varredura revelou que a instrumentação e metodologia resultaram na formação da smear layer no grupo 1 e remoção no grupo 2. Quanto à colonização bacteriana os dentes demonstraram $S$. anginosus confinados na superfície da smear layer nos canais radiculares nas amostras do grupo 1. No grupo 2, a colonização demonstrou diferentes perfis: juntamente com a colonização na parede do canal observaram-se massas de bactérias presentes dentro dos túbulos dentinários e em maior aumento detectaram-se bactérias penetrando no interior dos túbulos. Os autores concluíram que a smear layer resultante da terapia do canal radicular pode inibir a colonização bacteriana dos canais e também bloquear a penetração de bactérias dentro dos túbulos dentinários. 
Em 1994, HASHIOKA et $\mathrm{al}^{44}$ realizaram estudo bacteriológico por meio de procedimentos de cultura em condições anaeróbias em 28 canais radiculares de pacientes com periodontite apical com o intuito de correlacionar os sintomas clínicos com a composição da microbiota de canais infectados e ainda com a atividade enzimática das bactérias. De acordo com os sintomas os pacientes foram divididos em três grupos: grupo 1: dor espontânea e a percussão; grupo 2: dor a percussão e grupo 3: assintomáticos. A proporção de Peptococcus com atividade enzimática nas amostras dos grupos 2 e 3 foi $19 \%$ e $8 \%$, respectivamente; Eubacterium nos grupos 1, 2 e 3 foi $23 \%$, $14 \%$ e $8 \%$, respectivamente; Porphyromonas gingivalis nos grupos 1, 2 e 3 foi 19\%, 31\% e 4\%, respectivamente. A proporção de Prevotella com atividade enzimática no grupo 1 foi significantemente maior $(\mathrm{p}<0,01)$ que no grupo 2 . Observou-se que bactérias com atividade colagenolítica foram isoladas de canais com sintomas clínicos agudos, subagudos ou crônicos e as bactérias com a hialuronidase foram isoladas de canais com sintomas clínicos agudos ou subagudos. A proporção de bactérias com atividade colagenolítica nas amostras dos canais radiculares foi de $83 \%$ nos canais com área radiolúcida acima de $5 \mathrm{~mm}$ de diâmetro e $60 \%$ nos canais abaixo de $5 \mathrm{~mm}$ de diâmetro. Os autores sugerem que bactérias com atividade enzimática como a colagenase, condroitinase e hialuronidase tem um importante papel nos sintomas clínicos subagudos envolvendo dor à percussão.

De acordo com OGUNTEBI ${ }^{66}$, em 1994, o microambiente dos túbulos dentinários parece favorecer a seleção de algumas espécies de bactérias independente da etiologia do processo infeccioso; se cárie dentária ou necrose pulpar. Estas bactérias constituem um importante reservatório dos canais 
radiculares infectados, podendo reinfectá-los durante e após a terapia endodôntica. O caminho da reinfecção parece estar relacionado com infiltração coronária resultante de restaurações inadequadas e provavelmente pela proliferação de bactérias presentes nos túbulos dentinários. Devido à dificuldade de acesso para eliminação dessas bactérias pelo sistema de defesa do organismo do hospedeiro ou agentes antimicrobianos de administração sistêmica, a desinfecção local dos canais radiculares continua sendo um método importante no tratamento de dente com polpa dental necrótica. Também enfatizou-se a necessidade de novos estudos para identificar melhor os agentes antimicrobianos locais e utilizar sistemas que assegurem patência dos túbulos dentinários, permitindo maior contato entre os agentes antimicrobianos e as bactérias.

Em 1994, SUNDQVIST ${ }^{90}$, após revisão de literatura, enfatiza que todas as bactérias que normalmente habitam a cavidade bucal teoricamente têm a capacidade de invadir os canais radiculares durante e após necrose pulpar, todavia as bactérias presentes em canais radiculares infectados incluem um grupo restrito de espécies comparados com a microbiota total da cavidade bucal. Os canais radiculares permitem o crescimento de bactérias anaeróbias, capazes de fermentação de aminoácidos e peptídeos; e de bactérias cuja fonte energética provém da fermentação de carboidratos quando restringidas pela carência de nutrientes. Durante o curso de evolução do processo infeccioso, desenvolvem-se inter-relações entre espécies microbianas, proporcionando mudanças consideráveis na microbiota, formando associações resistentes e com interdependência mútua. Estas associações baseiam-se na demanda e relações nutricionais. Observações recentes afirmam que existem microcomunidades de bactérias agregadas nos canais radiculares adaptando-se às condições específicas existentes nas diferentes 
partes dos canais radiculares. A patogenicidade da microbiota polimicrobiana do canal radicular está na dependência do sinergismo bacteriano.

Por meio de estudo bacteriológico WRIGHT et $\mathrm{al}^{104}$, 1994, verificaram "in vitro" o efeito antimicrobiano e citotóxico das pastas Kri 1 (iodofórmio, cânfora, paramonoclofenol, mentol), e ZOE (óxido e zinco e eugenol) freqüentemente utilizadas na terapia endodôntica de dentes decíduos. Nesta pesquisa, Streptococcus faecalis foram espalhados em placas de petri contendo as pastas e posteriormente incubadas a $37^{\circ}$ C. Como controle Streptococcus faecalis foram espalhados em placas sem medicamentos. A pasta óxido de zinco e eugenol (ZOE) produziu maior zona de inibição bacteriana que a pasta Kri 1. A citotoxidade da pasta Kri 1 permaneceu alta em quatro horas de contato direto microrganismo-medicamento, enquanto a citotoxidade de ZOE diminuiu com o tempo. Tanto pasta Kri 1 como ZOE demonstraram alta citotoxidade em 24 horas de contato direto microrganismo-medicamento. Os resultados sugerem que ZOE apresentou melhor atividade antimicrobiana e citotoxidade mais baixa que a pasta Kri 1, ainda que o controle prolongado célula-medicamento pôde demonstrar que ambos medicamentos apresentam igualmente alta citotoxidade.

Para verificar a incidência de bacteremia seguida de tratamento endodôntico, em 1995, DEBELIAN; OLSEN; TRONSTAD ${ }^{27}$, por meio de cultura em anaerobiose, testes bioquímicos e antibiograma estudaram 26 dentes humanos permanentes unirradiculares portadores de necrose pulpar e periodontite apical crônica. Durante o tratamento endodôntico de 13 elementos (grupo 1) os canais foram instrumentados $2 \mathrm{~mm}$ além do forame apical, e nos outros 13 dentes (grupo 2) a instrumentação foi até $1 \mathrm{~mm}$ aquém do forame. Amostras de sangue foram 
coletadas dos pacientes durante a instrumentação e dez minutos após o término do tratamento. Todos os canais continham microrganismos e bactérias anaeróbias foram predominantes. Os espécimes mais freqüentes foram: Fusobacterium nucleatum, Prevotella intermedia, Propionibacterium acnes, Propionibacterium propinicus, Eubacterium lentum, Peptostreptococcus anaerobius e Actinomyces israelii. Os autores constataram que aos testes bioquímicos e antibiogramas os microrganismos isolados do canal radicular e corrente sangüínea dos pacientes apresentavam perfis idênticos, sugerindo que os microrganismos encontrados no sangue eram provenientes do canal radicular.

Com o propósito de verificar os efeitos da polpa dentária em relação à invasão de bactérias nos túbulos dentinários, em 1995, NAGAOKA et al ${ }^{63}$, realizaram estudo em 38 terceiros molares superiores humanos pareados; 19 eram desvitalizados e foram submetidos à terapia endodôntica e do lado oposto, a vitalidade dos dentes foi preservada. Em todos os espécimes confeccionaram-se cavidades classe $\mathrm{V}$ com aproximadamente $2,5 \mathrm{~mm}$ de diâmetro por 2,0mm de profundidade permanecendo expostas ao meio bucal por 30 e 150 dias. Posteriormente, os elementos foram extraídos e processados para análise pela microscopia eletrônica de varredura e microscopia óptica após coloração pela Brown e Brenn. Houve pequena penetração de bactérias nos túbulos dentinários dos espécimes após 30 dias do experimento, sem diferença estatisticamente significativa entre o dentes com ou sem vitalidade pulpar, todavia após 150 dias foi maior a invasão de bactérias para o interior dos túbulos dentinários dos dentes desvitalizados. Segundo os autores, os prolongamentos odontoblásticos, matriz extracelular e fluido dentinário dificultam a penetração de bactérias nos túbulos dentinários dos dentes vitalizados. 
Em 1995, PETERS; WESSELINK; MOORER ${ }^{71}$, em trabalho de revisão de literatura sobre as consequiências da permanência de bactérias nos túbulos dentinários do canal radicular após biomecânica, enfatizaram a necessidade de se utilizar curativo antibacteriano nos casos onde o canal radicular permanece temporariamente sem obturação após remoção do tecido pulpar necrótico e infectado. Não existem evidências de que medidas especiais devem ser adotadas para erradicar as bactérias no interior dos túbulos dentinários. Deve-se realizar uma técnica de obturação adequada imediatamente após as etapas de instrumentação e desinfecção permitindo que as bactérias remanescentes nos túbulos dentinários permaneçam inativas prevenindo a repopulação nos espaços do canal preparado. Na maioria dos casos, estas bactérias parecem não comprometer o sucesso da terapia endodôntica.

Utilizando-se da microscopia eletrônica de varredura, em 1995, SEN; PISKIN; DEMIRCI ${ }^{84}$, examinaram a microbiota dos canais radiculares infectados e o grau de penetração bacteriana nos túbulos dentinários de dez molares permanentes humanos. Os dentes apresentavam exposição pulpar ao meio bucal e lesões periapicais. Após a extração, as raízes palatinas dos superiores e distal dos inferiores foram separadas e confeccionaram-se ranhuras no sentido longitudinal das raízes, dividindo-as em duas partes. A seguir, os espécimes foram submetidos ao preparo para a análise microscópica. Os canais radiculares estavam altamente infectados e detectou-se a presença de microrganismos em todas as áreas dos canais. Em seis espécimes a microbiota constituiu-se de cocos e bacilos, formando colônias nas paredes dos canais, e também, em grau variado, penetrando nos túbulos dentinários dos terços médio e apical das raízes. A profundidade de penetração bacteriana no interior dos túbulos dentinários foi em média de $50 \mu \mathrm{m}$, 
atingindo $150 \mu \mathrm{m}$ no terço apical de dois espécimes. A penetração bacteriana não foi comum a todos os túbulos dentinários, enquanto grupos de bactérias eram evidentes em alguns túbulos, outros estavam isentos. Fungos também puderam ser encontrados ao longo das paredes dos canais de quatro espécimes. De acordo com os resultados, sugere-se o emprego de agentes antimicrobianos potentes nas terapias endodônticas.

Em 1995, TCHAOU et al ${ }^{94}$ estudaram "in vitro" por meio de cultura em anaerobiose a eficácia de materiais utilizados para obturação de canal radicular necrosado de 13 dentes decíduos. De acordo com os autores, quanto à efetividade medicamentosa, os dez materiais testados foram divididos em três categorias baseados na potencialidade da atividade antibacteriana, verificada por meio da extensão do halo de inibição. Categoria I: forte efeito antibacteriano $\mathrm{Ca}(\mathrm{OH})_{2}+$ CPC (hidróxido de cálcio misturado com paramonoclorofenol canforado), $\mathrm{ZnO}+$ CPC (óxido de zinco com paramonoclorofenol canforado) e ZOE + FC (óxido de zinco e eugenol misturado com formocresol); categoria II: médio efeito antibacteriano ZOE + CHX (óxido de zinco e eugenol misturado com clorexidina), pasta Kri (iodofórmio, cânfora, paramonoclorofenol e mentol), ZOE (óxido de zinco misturado com eugenol) e $\mathrm{ZnO}+\mathrm{H}_{2} \mathrm{O}$ (óxido de zinco misturado com água estéril) e categoria III: ausência ou mínimo efeito antibacteriano incluiam Vitapex, $\mathrm{Ca}(\mathrm{OH})_{2}+\mathrm{H}_{2} \mathrm{O}$ (hidróxido de cálcio misturado com água estéril) e vaselina utilizada como controle. Não houve diferença estatisticamente significante entre os materiais dentro de cada categoria, mas houve marcada diferença entre as três categorias, exceto para o efeito antibacteriano de $\mathrm{ZOE}+\mathrm{FC}$, no qual não foi diferente quando comparado com ZOE + CHX, Kri ou ZOE. 
Em 1996, BONOW; PINTO; BAMMANN ${ }^{11}$ avaliaram o efeito antimicrobiano das seguintes pastas e soluções empregadas na terapia endodôntica de dentes decíduos: GUEDES-PINTO (iodofórmio, Rifocort e paromonoclorofenol canforado), óxido de zinco (óxido de zinco, iodofórmio e a pasta de GUEDES-PINTO), hidróxido de cálcio (hidróxido de cálcio, iodofórmio e a pasta de GUEDES-PINTO) e mistura das pastas (óxido de zinco, hidróxido de cálcio, iodofórmio e a pasta de GUEDES-PINTO), formocresol, formocresol 1/5 e glutaraldeido a 2\% sobre Staphylococcus aureus e epidermidis, Streptococcus mutans e sanguis, Enterococcus faecalis, Escherichia coli e Bacillus subtilis. As drogas foram depositadas em placas de Petri e posteriormente os microrganismos. As amostras foram analisadas imediatamente após a mistura, 7, 14, 28, 60 e 90 dias. Após incubação a $37^{\circ} \mathrm{C}$, os diâmetros das zonas de inibição foram mensurados. As pastas demonstraram maior efeito antimicrobiano do que os líquidos. A pasta de óxido de zinco foi mais efetiva, seguida por GUEDESPINTO, pastas misturadas, pastas de hidróxido de cálcio, glutaraldeído a 2\%, formocresol e formocresol a 1/5. O efeito diminuiu com o tempo, sendo dependente da droga e cepas bacterianas testadas.

Com a finalidade de demonstrar as relações existentes entre a microbiota de canais radiculares infectados e a presença de sinais e sintomas clínicos, GOMES; LILLEY; DRUCKER ${ }^{39}$, em 1996, realizaram estudo bacteriológico, nos canais radiculares de 70 dentes permanentes humanos com coroas não intactas, empregando meios de cultura aeróbias e anaeróbias. Anaeróbios corresponderam a $64 \%$ das espécies isoladas das amostras. Os mais freqüentes foram Streptococcus seguidos por Peptostreptococcus micros, Prisotella melaninogenica e oralis, Eubacterium aerofaciens, Fusobacterium nucleatum e Prevotella buccae e 
intermedia. Em $70 \%$ dos canais sintomáticos e $30 \%$ dos canais assintomáticos detectou-se a presença de anaeróbios. Os autores constataram significantes relações entre: dor espontânea e espécies de Prevotella ou Peptostreptococci, ambos com $\mathrm{P}<0,01$; dor à percussão e espécies de Prevotella $(\mathrm{P}<0,01)$ ou anaeróbios $(\mathrm{P}<0,05)$; edema e espécies Eubacterium $(\mathrm{P}<0,01)$ ou espécies de Prevotella ou Peptostreptococcus micros, ambos com $\mathrm{P}<0,05$; exudato purulento e F. necrophorum $(\mathrm{P}<0,01)$, Prev. loescheii, Streptoccoccus constellatus ou espécies de Bacteroides (cada $\mathrm{P}<0,05)$, canal drenando e anaeróbios facultativos $(\mathrm{P}<0,01)$ e qualquer espécie do gênero Eubacterium, Peptostreptococcus, Prevotella ou Propionibacterium (cada $\mathrm{P}<0,05$ ). Pode-se concluir que muitos sinais e sintomas clínicos evidenciados nos canais radiculares de dentes infectados estão significantemente associados com espécies bacterianas específicas.

LOMÇALI; SEN; ÇANKAYA ${ }^{54}$, em 1996, investigaram por meio da microscopia eletrônica de varredura a porção apical de 17 raízes de pré-molares e molares permanentes humanos com lesões periapicais crônicas. Foram observadas extensas áreas de reabsorção com formação de lacunas. Em algumas regiões, certas lacunas apresentavam-se revestidas por uma "malha orgânica" constituída por numerosas bactérias e seus produtos. Leveduras também foram detectadas em dois espécimes. Na superfície radicular adjacente ao forame apical a maioria dos espécimes demonstrou placas bacterianas envolvidas em uma matriz extracelular e recobertas por uma estrutura mascarando detalhes da superfície radicular. De acordo com os resultados, o material extracelular pode ser importante fator de sustentação da inflamação e infecção periapical servindo de substrato para os microrganismos. Novos procedimentos e substâncias devem ser empregados com 
o intuito de eliminar os microrganismos e seus produtos em infecções periapicais persistentes.

A penetração bacteriana nos túbulos dentinários nos terços cervical médio e apical do canal radicular de dentes permanentes humanos recém-extraídos foi observada por $\operatorname{LOVE}^{56}$, em 1996. Um total de trinta dentes com ausência de cárie, tiveram as coroas eliminadas e os canais radiculares instrumentados. A seguir, as raízes de 20 dentes foram seccionadas longitudinalmente, inoculadas com Streptococcus gordonii e incubados em anaerobiose por três semanas. As raízes restantes utilizadas como controle tiveram cortes radiculares transversais, sem inoculação com os microrganismos. Todos os cortes obtidos dos espécimes foram processados e submetidos à coloração de Brown e Brenn. O autor constatou padrão similar de invasão tubular nos terços cervical e médio das raízes, representada por uma intensa camada superficial de penetração envolvendo a maioria dos túbulos. A distribuição e profundidade de penetração nos túbulos foi variável, atingindo um máximo de $200 \mu \mathrm{m}$ nos terços médio e cervical e no apical $60 \mu \mathrm{m}$. No terço apical, observaram-se poucos túbulos infectados, exceto em um caso onde a dentina da camada superficial externa encontrava-se desnuda, devido à reabsorção externa. Em nenhum caso, as bactérias atingiram a dentina atravessando cemento e nem no grupo controle. Os resultados permitiram concluir que houve uma variação na extensão de invasão bacteriana nos túbulos dentinários dos canais radiculares infectados. O padrão de invasão favorecia uma técnica de instrumentação que resulta-se em preparação apical mínima devido a pequena e limitada penetração de bactérias mas, que possibilitasse o alargamento coronário para a remoção da grande quantidade de dentina infectada nos terços cervical e médio. 
Pela microscopia eletrônica de varredura, SIQUEIRA JÚNIOR; UZEDA; FONSECA ${ }^{88}$, em 1996, examinaram "in vitro" a penetração de bactérias anaeróbias nos túbulos dentinários radiculares de incisivos bovinos recémextraídos. Os dentes selecionados tiveram o ápice e a coroa eliminados, o canal radicular alargado a um diâmetro de aproximadamente $2,0 \mathrm{~mm}$ e remoção do cemento. As amostras foram seccionadas transversalmente obtendo-se dois cilindros de cerca de $4 \mathrm{~mm}$ de altura de cada dente e estes cilindros permaneceram por três minutos em solução de ácido cítrico para remoção da smear layer. Posteriormente, os espécimes foram incubados em condições anaeróbias e inoculados com seis grupos de bactérias: Porphyromonas endodontalis, Fusobacterium nucleatun, Actinomyces israelii, Porphymonas gingivalis, Propionibacterium acnes e Enterococcus faecalis. As análises microscópicas puderam revelar a presença de todas as espécies de bactérias empregadas no experimento no interior dos túbulos dentinários em diferentes profundidades. A maioria dos túbulos apresentava bactérias em seu interior a uma grande extensão. Segundo os autores, as bactérias localizadas nos túbulos dentinários a uma pequena distância da superfície pulpar podem ser removidas durante a preparação mecânica dos canais radiculares ou ainda serem destruídas pela ação química das soluções irrigadoras, todavia, as bactérias localizadas mais profundamente podem sobreviver se a obturação do canal radicular não possibilitar um selamento adequado; a percolação de fluídos teciduais ou saliva poderá servir de substrato para as bactérias remanescentes que crescerão e se multiplicarão podendo causar danos aos tecidos periapicais e conseqüentemente fracasso do tratamento endodôntico. 
Por meio de cultura microbiológica, em 1997, GOMES; FONSECA; GUEDES-PINTO $^{38}$ verificaram a eficiência do procedimento biomecânico e da pasta utilizada na obturação de 25 dentes decíduos necrosados de crianças entre 3 e 7 anos de idade. Inicialmente, por meio de um cone de papel estéril introduzido no interior do canal obteve-se a primeira amostra. Terminada a instrumentação dos canais com três limas em série crescente e irrigação com Endo-PTC e líquido de Dakin, coletou-se a segunda amostra e obturaram-se os canais com uma pasta constituída por partes iguais de iodofórmio, paramonoclorofenol canforado e Rifocort, após sete dias obteve-se a terceira amostra. Os cones de papel estéreis utilizados nas coletas das amostras foram nas três etapas da pesquisa transferidos para um tubo de ensaio contendo caldo de tioglicolato para cultivo dos microrganismos. A cultura foi positiva em $100 \%$ das amostras, antes e após o preparo biomecânico. Seguida a obturação dos canais com a pasta a cultura foi positiva em $52 \%$ e negativa em $48 \%$ dos casos.

Em 1997, RIBEIRO ${ }^{76}$ analisou a distribuição das bactérias nas estruturas mineralizadas de dentes permanentes portadores de necrose pulpar e nos granulomas apicais. Trinta e duas raízes dentárias com lesões periapicais, firmemente aderidas a seus ápices e 16 lesões isoladas foram distribuídas em três grupos distintos: grupo A - 16 dentes com granulomas cortados longitudinalmente; grupo B - 16 dentes com granuloma cortados transversalmente e grupo C - 16 granulomas apicais. Os espécimes foram analisados pela microscopia óptica, empregando-se as técnicas de coloração pela hematoxilina-eosina de Harris e de Brown e Brenn. Houve alta frequiência de bactérias Gram-positivas e Gramnegativas no lume do canal principal e nas ramificações constituintes do delta apical, e em menor proporção, nos túbulos dentinários, nos cementoplastos, na 
superfície radicular externa e nos granulomas apicais. Concluindo que nos dentes com necrose pulpar e granulomas apicais, as bactérias envolvem todo o sistema de canal radicular, incluindo-se os túbulos dentinários, e freqüentemente os tecidos da região periapical. Ressaltando-se, mais uma vez, a necessidade do preparo biomecânico auxiliado por substâncias químicas antibacterianas, emprego de curativos no interior do canal, e selamento adequado do canal radicular, em tratamento endodôntico.

Empregando a microscopia eletrônica de varredura, em 1998, CALAS et $\mathrm{al}^{18}$ estudaram "in vitro", a interferência da smear layer na adesão e colonização de cepas bacterianas anaeróbias em 16 incisivos bovinos de animais adultos. A partir da extração, os dentes foram seccionados na porção coronária e apical e o remanescente da raiz foi cortada em vários discos de $3 \mathrm{~mm}$ de espessura. Estes discos foram divididos ao meio no sentido do longo eixo axial do dente obtendo-se dois blocos. A seguir, com a broca esférica realizaram-se pequenas cavidades na superfície dentinária interna do canal radicular com o intuito dessas superfícies serem recobertas pela smear layer. Uma das porções de cada bloco foi pré-tratada com uma solução composta de ácido cítrico a $6 \%$ por cinco minutos e hipoclorito de sódio a $6,25 \%$ por dez minutos. A outra metade do bloco foi somente lavada com água destilada e utilizada como controle. As amostras foram imersas em tubos contendo suspensão da bactéria Prevotella nigrescens em condições anaeróbias por um período de três horas de incubação e a seguir preparadas para a análise microscópica avaliando-se o número de células bacterianas por área. A adesão de $P$. nigrescens foi menos marcante em todas as amostras tratadas com a solução irrigadora, concluindo-se que removendo-se a smear layer, a superfície interna do canal radicular torna-se limpa e o número de células bacterianas que 
aderem à dentina diminui, desse modo recomenda-se o emprego de agentes quelantes na fase de irrigação final antes da obturação.

Por meio de métodos específicos de cultura em anaerobiose e posterior coloração de Gram, DOUGHERTY et $\mathrm{al}^{28}$, em 1998, verificaram a presença de bactérias melaninogênicas nas porções cervical e apical do canal radicular de 18 dentes permanentes humanos com polpa necrosada e lesão periapical. Os resultados confirmaram a presença de bactérias melaninogênicas no canal radicular de 12 amostras (67\%). Destes 12 dentes, oito apresentaram exposição pulpar por cárie, e quatro permaneceram com coroas intactas. Em sete raízes identificou-se a presença de Prevotella nigrescens nos segmentos apical e cervical, seis desses espécimes tinham exposição pulpar por cárie. Das 12 amostras infectadas com bactérias melaninogênicas, em seis raízes detectaram-se duas espécies diferentes de bactérias melaninogênicas sendo $P$. nigrescens sempre uma das isoladas. $P$. nigrescens foi isolada de oito segmentos coronários e nove apicais. Prevotella melaninogenica foi isolada de cinco segmentos coronários e três apicais. Porphyromonas gingivalis foram isoladas juntamente com $P$. nigrescens do segmento coronário de um dente e segmento apical de vários. As bactérias $P$. nigrescens foram mais freqüentes tanto no segmento coronário como apical dos canais radiculares infectados.

Para avaliar o efeito antimicrobiano da solução de gluconato de clorexidina empregada como substância irrigadora do canal radicular durante a terapêutica endodôntica, LEONARDO et al ${ }^{52}$, em 1999, selecionaram 22 canais radiculares de dentes humanos com necrose pulpar e lesão periapical crônica visível radiograficamente. Após abertura coronária por meio de um cone de papel 
estéril introduzido no interior do canal obteve se a primeira amostragem. A seguir, realizou-se a biomecânica dos canais utilizando gluconato de clorexidina a $2 \%$ como irrigante. A segunda amostra foi obtida por meio de um cone de papel estéril introduzido no canal após o dente ter permanecido por 48 horas selado. A análise por meio do método de cultura em anaerobiose permitiu averiguar a zona de inibição de crescimento microbiano em milímetros. Pôde-se detectar antes da biomecânica que a porcentagem de unidades formadoras de colônias foi de $45 \%$ e $82 \%$ respectivamente para Streptococcus mutans e anaeróbios, todavia quarenta e oito horas após a biomecânica estes valores diminuíram para 0\% e 18\% para Streptococcus mutans e anaeróbios, respectivamente. Segundo os autores, em dentes com necrose pulpar e lesão periapical crônica, o emprego de soluções irrigantes com alto potencial antibacteriano juntamente com medicação intracanal entre as sessões facilita o processo de reparo do tecido apical e periapical após tratamento endodôntico.

\subsection{Conceitos atuais de biofilmes microbianos}

A formação de microcolônias em superfícies inerte ou viva constitui uma importante estratégia de sobrevivência das bactérias que por meio de sucessivas divisões celulares produzem células filhas, as quais unem-se entre si em meio a uma matriz de polissacarídeos ${ }^{74}$. Os próprios microrganismos produzem a matriz de polissacarídeos e esta funciona como um escudo, permitindo sua sobrevivência em ambientes hostis. As diferentes bactérias colaboram entre si para tornarem-se mais fortalecidas ${ }^{25,73,74}$. Os biofilmes microbianos também podem ser formados por protozoários e fungos, embora os bacterianos sejam os mais encontrados na natureza ${ }^{85}$. 
Estima-se que $65 \%$ das infeções bacterianas em humanos envolvam biofilmes $^{74}$ e, nestes casos, a cronicidade constitui sua característica marcante, podendo durar meses, anos ou mesmo toda a vida, inclusive em pessoas com condição imunológica satisfatória.

Os biofilmes microbianos são estruturas altamente organizadas, estes contêm canais de água, possibilitando a chegada de nutrientes e a remoção de resíduos, semelhante a função do sistema circulatório ${ }^{73,74}$.

As comunidades microbianas organizadas em biofilmes apresentam um metabolismo complexo, exibem diferentes padrões de expressão genética e podem dar origem a bactérias planctônicas, as quais se multiplicam e dispersam rapidamente, sujeitando-se à ação do sistema imunológico e dos agentes antimicrobianos, ao contrário daqueles microrganismos que permanecem organizados em biofilmes ${ }^{25}$.

Segundo SHEARER ${ }^{85}$, em 1996, em comparação com microrganismos planctônicos, a adesão desses elementos possibilita diversas vantagens para sua sobrevivência como 1) retenção: os microrganismos componentes do biofilme são conservados na superfície em um ecossistema cooperativo; 2) nutrição: microrganismos componentes do biofilme apresentam vantagem nutricional, em função dos nutrientes orgânicos e inorgânicos confinados pela matriz do biofilme e 3) resistência: a formação do biofilme confere aos microrganismos certo grau de resistência às substâncias antimicrobianas, resultante da proteção pela matriz de polissacarídeos ${ }^{85}$. 
Até recentemente, os biofilmes microbianos eram conhecidos principalmente pela sua capacidade de se aderir e corroer encanamentos. Mas há evidências destes estarem também relacionados com numerosos problemas médicos como a colonização de próteses valvares, articulares, catéteres, lentes de contato, além de tecidos como os dentes, gengiva, pulmão, ouvido, trato urogenital, entre outros ${ }^{25,74}$.

Atualmente tem sido demonstrado que a maioria das bactérias se agrega formando biofilmes microbianos, que se desenvolvem preferencialmente em superfícies inertes ou em tecidos mortos, como nos seqüestros ósseos. Podendo também formar-se em tecidos vivos, sendo a endocardite infecciosa um exemplo característico $^{74}$.

POTERA $^{74}$, em 1999, enfatiza que as infecções relacionadas com os biofilmes microbianos apresentam características em comum. Estes crescem lentamente, em um ou mais locais e as infecções por eles provocadas geralmente produzem sintomas discretos. Quando organizadas em colônias, as bactérias liberam antígenos e estimulam a produção de anticorpos. No entanto, estes não são capazes de alcançá-las em meio à barreira de proteção de polissacarídeos extracelulares desenvolvida.

Além disso, os biofilmes microbianos são grandes o suficientes para não serem derrotados pelo sistema imunológico. Enquanto as células sangüíneas, com aproximadamente 15 micrometros de diâmetro podem identificar e fagocitar as bactérias livres, o mesmo não ocorre com os biofilmes microbianos, pois podem atingir 50 a 100 micrometros de diâmetro ${ }^{74}$. Mesmo em indivíduos com resposta 
imune humoral e celular satisfatórias, estas infecções raramente resolvem-se pela da ação do sistema imunológico.

A antibioticoterapia geralmente reverte os sintomas causados pelas bactérias liberadas a partir dos biofilmes (bactérias planctônicas), porém as colônias aderidas às superfícies permanecem intactas. Por isso as infecções associadas aos biofilmes apresentam recorrências após os ciclos de antibioticoterapia. A liberação de bactérias a partir dos biofilmes parece ser préprogramada e constante ${ }^{74}$.

As bactérias nos biofilmes são raramente atingidas pela resposta imune, elas são muito menos suscetíveis aos antibióticos quando comparadas com suas correspondentes livres e isso se dá por meio de múltiplos mecanismos. Por exemplo, muitos antibióticos, como a penicilina, impedem as bactérias de sintetizarem certos constituintes de sua parede, porém estudos recentes têm demonstrado que, nos biofilmes, $40 \%$ das proteínas da parede das bactérias são diferentes. Portanto, o alvo dos antibióticos pode desaparecer quando os microorganismos formam biofilmes, ou então, mesmo que estas proteínas estejam presentes, muitos dos antibióticos não têm como alcançá-las pela incapacidade de penetrar nos biofilmes microbianos, pois a matriz de polissacarídeos diminui a velocidade de difusão das drogas. Além disso, as bactérias nos biofilmes podem sobreviver sem se dividir, tornando-se resistentes aos antibióticos que atuam somente nas bactérias em divisão ${ }^{74}$. 
A diversidade microbiana também constitui uma estratégia de defesa, pois seus diferentes estados metabólicos contribuem para a resistência aos variados desafios do ambiente ${ }^{25}$.

A formação de um biofilme maduro depende de quatro etapas seqüenciais: 1) transporte de microrganismos; 2) adesão microbiana inicial; 3) adesão por meio da produção de polissacarídeos extracelulares e 4) colonização pelo crescimento dos microrganismos firmemente aderidos ${ }^{15}$.

A placa bacteriana constitui o exemplo mais comum de biofilme microbiano e está associado com a cárie dentária, a gengivite e a doença periodontal, sendo composta por cerca de 300 espécies diferentes de bactérias. Vários fatores bacterianos e do hospedeiro estão envolvidos na formação de uma placa patogênica, capaz de levar à iniciação e progressão da doença periodontal, por exemplo, um aspecto importante no processo é a interação entre vários tipos de bactérias bucais.

As bactérias que infectam a região periapical por meio do canal radicular, via hematogênica, quando isoladas, quase sempre são eliminadas pelas células inflamatórias ou do sistema imunológico. Todavia, quando coagregadas, em colônias, ou aderidas à superfície radicular, formam placas dentobacterianas (biofilmes) dificultando a ação das células fagocitárias, devido às suas dimensões ${ }^{76}$. 
A identificação dos mecanismos genéticos e moleculares do desenvolvimento dos biofilmes microbianos constitui um campo de estudo promissor para a sua prevenção e tratamento ${ }^{25}$. 
3 PROPOSIÇÃO 


\section{PROPOSIÇÃO}

Considerando os questionamentos anteriormente relacionados quanto à importância dos microrganismos na etiopatogenia das doenças pulpares e periapicais, propusemos no presente trabalho:

3.1 Analisar a presença das bactérias planctônicas, colônias bacterianas e biofilmes microbianos na câmara pulpar e canal radicular de dentes decíduos com pulpites e necrose pulpar;

3.2 Analisar a presença das bactérias planctônicas, colônias bacterianas e biofilmes microbianos nas estruturas dos tecidos coronários e radiculares mineralizados de dentes decíduos com pulpites e necrose pulpar;

3.3 Analisar a relação destas bactérias com a regularidade das superfícies coronárias e radiculares, especialmente com depósito de dentina reacional, áreas de reabsorções radiculares e superfície apical de dentes decíduos com pulpites e necrose pulpar. 


\section{MATERIAL E MÉTODOS}

\subsection{Amostragem}

\subsubsection{Obtenção das amostras}

Foram coletados de forma aleatória 83 dentes decíduos, tanto superiores como inferiores, extraídos em consultórios particulares.

\subsubsection{Seleção das amostras}

A amostra consistiu em 32 dentes decíduos com polpa inflamada ou necrosada de crianças entre 4 e 8 anos de idade, ambos os sexos. Os dentes apresentavam cárie de extensão e profundidade variadas, todavia com estrutura coronária que possibilitasse a restauração, raízes íntegras ou até no máximo 2/3 das raízes, ausência de tratamento pulpar e fraturas radiculares.

\subsubsection{Distribuição das amostras}

Grupo A: 16 dentes cortados longitudinalmente (2 incisivos centrais superiores, 8 molares superiores e 6 molares inferiores).

Grupo B: 16 dentes cortados transversalmente (1 incisivo central superior, 1 canino superior , 8 molares superiores e 6 molares inferiores).

\subsubsection{Preparação das amostras}




\subsubsection{Fixação}

Imediatamente após as extrações, os dentes foram colocados em frascos individuais contendo formaldeído a $10 \%$ por um período mínimo de 48 horas.

\subsubsection{Desmineralização dos espécimes}

Após a fixação, os espécimes foram submetidos ao processo de desmineralização, em solução de ácido etilenodiaminotetracético (EDTA) a 5\%, tamponado com pH 7,0. A solução foi trocada três vezes por semana. Ao término de 70 dias, em média, os espécimes estavam desmineralizados e os dentes do grupo A foram seccionados no sentido longitudinal e divididos em duas partes enquanto os dentes do grupo B foram seccionados na altura da coroa a $2 \mathrm{~mm}$ da junção amelo-cementária. Considerou-se finalizado o processo de desmineralização, quando o dente apresentava-se com consistência borrachóide, sem resistência ao corte pela lâmina de microtomia.

\subsubsection{Inclusão}

As peças foram lavadas em água corrente, desidratadas em álcool, diafanizadas em xilol, incluídas em parafina e posteriormente montadas em blocos de madeira.

\subsubsection{Microtomia}


A partir dos blocos, foram realizados cortes semi-seriados de $4 \mu \mathrm{m}$, por meio de um micrótomo marca Leica (RM 2045). Para os espécimes do grupo A, obtido o corte que permitisse a visualização do lume do canal no seu longo eixo, realizaram-se mais nove cortes adicionais. Os espécimes do grupo B sofreram cinco cortes transversais na região do terço coronário até o médio das raízes e cinco cortes do terço médio ao apical das raízes.

\subsubsection{Coloração Hematoxilina-Eosina de Harris (H.E.)}

Selecionaram-se cortes de cada espécime a serem corados por hematoxilina-eosina e examinados microscopicamente quanto: à morfologia, ao conteúdo da câmara pulpar, do canal radicular, dos túbulos dentinários, às áreas de reabsorções dentinárias e cementárias e à presença de lacunas de Howship (Figuras 1, 2, 3, 4, 5 e 6).

As soluções e passos da técnica H.E. estão apresentados conforme preconizados e registrados nos protocolos técnicos da Disciplina de Patologia da FOB-USP, a saber:

\subsection{Soluções}

Hematoxilina de Harris ${ }^{93}$

Hematoxilina

$1 \mathrm{~g}$

Álcool absoluto

$10 \mathrm{ml}$

Alúmen de potássio (MERCK)

$20 \mathrm{~g}$

Água destilada

$200 \mathrm{ml}$ 
Óxido de mercúrio amarelo $\quad 0,5 \mathrm{~g}$

Dissolver a hematoxilina em álcool e o alúmen em água. Misturar as soluções em água aquecida. Adicionar o óxido de mercúrio lentamente reaquecendo a solução até que atinja a coloração roxo-escura. Após o resfriamento filtrar a solução.

Eosina de Lison

Solução A

Eosina

$10 \mathrm{~g}$

Água destilada

$200 \mathrm{ml}$

Solução B

Bicromato de potássio

$5 \mathrm{~g}$

Água destilada

$800 \mathrm{ml}$

Solução C

Ácido pícrico (MERCK)

$5 \mathrm{~g}$

Água destilada

$100 \mathrm{ml}$

Solução A + Solução B e acrescentar 20ml de solução saturada de ácido pícrico (solução C).

Álcool-Ácido (Diferenciador)

Álcool $95^{\circ}$

$990 \mathrm{ml}$

Ácido clorídrico P.A .

$10 \mathrm{ml}$ 
Água destilada

$253 \mathrm{ml}$

\subsection{Procedimentos técnicos}

- Desparafinizar e hidratar os cortes de acordo com os métodos convencionais;

- Colocar lâmina sobre um suporte e cobrir o corte com hematoxilina de Harris por cinco minutos;

- Lavar em água corrente para retirar o excesso de corante;

- Se necesário diferenciar, em ácido clorídrico a $1 \%$ até que saiam as "nuvens vermelhas" dos cortes;

- Lavar em água corrente ou em amoniacal (água com algumas gotas de amoníaco puro);

- Corar pela eosina por 1-5 minutos;

- Lavar em água corrente;

- Desidratar, clarificar e montar.

\subsubsection{Coloração de Brown e Brenn}

Outros cortes foram selecionados para coloração pela técnica de Brown e Brenn ${ }^{13}$. Os espécimes foram analisados sob microscopia quanto aos seguintes aspectos: presença, distribuição e localização de bactérias Gram-positivas e Gramnegativas na câmara pulpar e no sistema de canais radiculares, nos túbulos dentinários e nas lacunas de Howship (Figuras 1, 2, 3, 4, 5 e 6).

\subsection{Soluções}


Hematoxilina de Harris ${ }^{93}$

Hematoxilina

$1 \mathrm{~g}$

Álcool absoluto

$10 \mathrm{ml}$

Alúmen de potássio

$20 \mathrm{~g}$

Água destilada

$200 \mathrm{ml}$

Óxido de mercúrio amarelo

$0,5 \mathrm{~g}$

Iodo de Gram 1\% (Lugol)

Iodo

$1 \mathrm{~g}$

Iodeto de potássio

$2 \mathrm{~g}$

Água destilada

$300 \mathrm{ml}$

Dissolver o iodo e o iodeto de potássio em água destilada. Deixar em repouso em frasco escuro com tampa de vidro e filtrar após 24 horas.

Solução de Galego

Formaldeído

$1 \mathrm{ml}$

Ácido acético glacial (MERCK)

$0,5 \mathrm{ml}$

Água destilada

$50 \mathrm{ml}$

Cristal Violeta a $1 \%$

Cristal violeta

$1 \mathrm{~g}$

Álcool etílico

$10 \mathrm{ml}$

Ácido carbólico

$2 \mathrm{~g}$

Água destilada

$100 \mathrm{ml}$

Observação: repousar por 24 horas e filtrar antes do uso

Éter-Acetona 
Éter etílico

Acetona
$80 \mathrm{ml}$

$120 \mathrm{ml}$

Fucsina Básica (estoque)

Fucsina

$0,25 \mathrm{~g}$

Água destilada

$100 \mathrm{ml}$

Solução de Trabalho

Solução de estoque

$1 \mathrm{ml}$

Água destilada

$10 \mathrm{ml}$

Deixar em repouso por 24 horas e filtrar antes do uso

Ácido Pícrico-Acetona a 0,1\%

Ácido pícrico

$0,1 \mathrm{~g}$

Acetona

$100 \mathrm{ml}$

Acetona-Xilol

Acetona

$50 \mathrm{ml}$

Xilol

$50 \mathrm{ml}$

\subsection{Procedimentos técnicos}

- Desparafinizar e hidratar;

- Corar com hematoxilina de Harris por cinco minutos;

- Passar no diferenciador por um minuto;

- Lavar em água corrente por cinco minutos; 
- Secar as bordas da lâmina com papel filtro evitando ressecar o corte, corar com cristal violeta por dois minutos;

- Escorrer o excesso de corante e cobrir os cortes com lugol por um minuto;

- Escorrer o excesso da solução, diferenciar os cortes éter-acetona até não ter mais corante;

- Lavar as lâminas rapidamente em água destilada e secar com papel de filtro os cortes;

- Corar com solução de trabalho por três minutos;

- Escorrer o excesso do corante, lavar rapidamente com água destilada e secar as lâminas sem secar os cortes;

- Diferenciar na solução de galego por três minutos;

- Lavar as lâminas em água destilada e secá-las sem secar os cortes.

- Mergulhar em seguida em acetona pura por dez segundos a um minuto;

- Diferenciar em ácido pícrico+acetona até que o tecido tome coloração rósea amarelada por dez segundos;

- Esse passo, o mais crítico, deve ser realizado no sentido de retirar a maior parte de fucsina;

- Imergir três vezes em acetona pura sob leve agitação, para remover completamente o ácido pícrico;

- Lavar em mistura de partes iguais de acetona+xilol por 15 segundos;

- Clarear em xilol dez banhos; 
- Montar os cortes em lâminas

\subsubsection{Análise microscópica}

As lâminas inicialmente foram examinadas em menor aumento, sendo seqüencialmente analisadas em aumentos maiores até a objetiva 100x com óleo de imersão, a partir de um microscópio óptico binocular Olympus CBA. Os critérios de avaliação dos espécimes e os resultados foram tabulados em quadros demonstrativos agrupando os aspectos morfológicos possíveis de registro baseados em sua localização: câmara pulpar e canal radicular; dentina e região apical (Figuras 1, 2, 3, 4, 5 e 6).

\subsubsection{Fotomicrografias}

Algumas amostras foram selecionadas para documentação fotográfica utilizando-se um aparelho Zeiss da Disciplina de Patologia da Faculdade de Odontologia de Bauru (FOB-USP). 
5 RESULTADOS 


\section{RESULTADOS}

À partir da análise por meio do microscópio óptico os dados obtidos serão apresentados considerando os aspectos morfológicos da câmara pulpar e canal radicular incluindo o seu conteúdo; a distribuição das bactérias no lume do canal, nos túbulos dentinários e na região apical, de cortes longitudinais (grupo A) e transversais (grupo B) de dentes decíduos com pulpites ou necrose pulpar corados pela técnica da hematoxilina-eosina de Harris e pela coloração de Brown e Brenn.

\subsection{Grupo A - Dentes cortados longitudinalmente}

Neste grupo, os cortes apresentavam uma distribuição e inter-relação tecidual bem característica com o conteúdo pulpar.

\subsubsection{Observações relativas à câmara pulpar e canal radicular (Figura 1)}

Na maioria dos espécimes, a câmara pulpar e canal radicular, foram examinados em toda a extensão de suas paredes e limites. Apenas em três espécimes, a incidência do corte e a irregularidade morfológica do canal radicular impossibilitaram a visualização completa.

Detectaram-se dez espécimes com pulpite e seis espécimes com necrose pulpar. A câmara pulpar estava aberta em sete e fechada em nove espécimes. Em dentes com pulpite ou necrose pulpar a superfície interna apresentou-se irregular com depósitos de dentina reacional com espessuras variadas e soluções de 
continuidade (Figuras 12A, 12C e 15C). Em apenas um espécime, um nódulo pulpar livre foi observado localizado na câmara pulpar.

Nos 16 espécimes analisados, havia conteúdo pulpar detectável microscopicamente. Bactérias livres destacaram-se na dentina e no exsudato de todos os espécimes com necrose pulpar e estavam presentes na dentina, no exsudato, no interior das células e na matriz extracelular de seis espécimes com pulpite.

Todas as amostras com necrose pulpar e seis com pulpite demonstraram a presença de colônias bacterianas, que coradas pela técnica de Brown e Brenn, permitiram-nos verificar ser alta a freqüência de cocos e bacilos Gram-positivos e Gram-negativos, e menos freqüentes os espirilos localizados no exsudato, na parede dentinária interna e na área inflamada. No tecido pulpar sadio não foram encontradas.

Biofilmes foram observados na parede dentinária interna de todos os espécimes com necrose pulpar e em dois espécimes com pulpite.

\subsubsection{Observações relativas à dentina (Figura 2)}

Em quase todos os espécimes, em conseqüência do processo degenerativo, verificou-se uma dentina desorganizada com seus túbulos dentinários irregularmente distribuídos. A incidência do corte e as irregularidades em seus trajetos impediram uma visualização completa dos túbulos ao longo de suas extensões. 
A densidade bacteriana intratubular foi considerada moderada nas áreas próximas das lesões de cárie na maioria dos espécimes. A quantidade de túbulos infectados por área e o número de microrganismos foram considerados elevados nas regiões da cárie propriamente dita em relação às outras áreas. Isto demonstrou porque os túbulos encontravam-se dilatados, varicosos e com focos de liquefação nesta região e preservados nas demais (Figuras 7, 8, 9 e 10).

Na região da lesão de cárie, em 15 espécimes, observaram-se bactérias livres, em colônias externas e biofilmes microbianos externos Gram-positivos e Gram-negativos, com predomínio de Gram-positivos (Figuras 9A e 9B). Em apenas um espécime não se pôde observar a lesão de cárie, devido à incidência dos cortes. Na dentina intratubular, formas cocares e bacilos predominantemente Gram-negativos foram localizados no teto da câmara pulpar de todos os espécimes. Nos dentes com necrose, localizavam-se na parede lateral, na dentina radicular e na dentina apical. Em alguns dentes com pulpite na parede lateral e dentina radicular. Em cinco espécimes com necrose pulpar e quatro espécimes com pulpite detectaram-se bactérias na dentina do soalho da câmara pulpar (Figuras 13A e 13B).

\subsubsection{Observações relativas à região apical (Figura 3)}

A superfície apical apresentou-se irregular em todos os espécimes analisados, provocando alterações significantes na forma anatômica das raízes. Estas alterações morfológicas estavam relacionadas às áreas de reabsorção cementárias e dentinárias ativas com presença de clastos. Em 11 espécimes as 
áreas de reabsorção estavam reparadas com depósitos parciais de tecido mineralizado cementóide.

Em cinco espécimes com necrose pulpar, as lacunas de reabsorção apresentaram-se ora vazias, ora preenchidas por cocos e bacilos Gram-positivos e Gram-negativos e espirilos Gram-negativos livres, em colônias ou constituindo biofilmes; localizados nos tecidos cementários e dentinários irregulares (Figuras 18 e 19). Em três espécimes detectaram-se bactérias na região apical intratubular. 


\subsection{Grupo B - Dentes cortados transversalmente}

Neste grupo, os cortes demonstravam, numa vista panorâmica dos terços coronário ao apical das raízes, o lume do canal principal e superfície radicular lateral.

\subsubsection{Observações relativas à câmara pulpar e canal radicular (Figura 4)}

Aos cortes transversais, os canais radiculares apresentaram-se com forma ovalada ou elíptica em todos os espécimes e à medida que se aproximavam do ápice adquiriam formas circulares.

Encontraram-se nove espécimes com pulpite e sete espécimes com necrose pulpar. A superfície interna apresentava-se irregular com alguns depósitos de dentina reacional, com variações na forma e na espessura, não necessariamente de forma contínua, tanto nos dentes com pulpite como nos dentes com necrose pulpar. Nódulos pulpares livres foram abservados em quatro espécimes.

No conteúdo pulpar, havia bactérias livres na dentina, no exsudato, no interior das células e na matriz extracelular de espécimes com pulpite e na dentina e no exsudato de todos espécimes com necrose pulpar.

Colônias bacterianas predominantemente formadas por cocos e bacilos Gram-positivos e Gram-negativos foram encontradas no exsudato e na parede 
dentinária interna de todos os espécimes com necrose pulpar e na área inflamada de quatro espécimes com pulpite. No tecido pulpar sadio não foram encontradas.

Biofilmes na parede dentinária interna foram detectados em seis espécimes com necrose pulpar e em um espécime com pulpite.

\subsubsection{Observações relativas à dentina (Figura 5)}

Os túbulos dentinários foram encontrados predominantemente preservados. Em todos os espécimes com necrose pulpar e em dois espécimes com pulpite detectaram bactérias no terço pulpar e raramente atingindo o terço médio da camada dentinária, e cujos aspectos morfológicos evidenciados pela técnica de coloração de Brown e Brenn possibilitaram evidenciar cocos e bacilos Gram-positivos e Gram-negativos, com predomínio de formas Gram-negativas. Cocos e bacilos Gram-positivos e Gram-negativos livres, em colônias externas e biofilmes microbianos externos foram encontrados em três espécimes com necrose pulpar. Na maioria dos espécimes, a densidade bacteriana intratubular foi leve. As bactérias localizavam-se preferencialmente na parede lateral e na dentina radicular. Em cinco espécimes com necrose pulpar e em dois com pulpite estavam presentes na dentina apical.

\subsubsection{Observações relativas à região apical (Figura 6)}

Em todos os espécimes a superfície radicular apical apresentou-se irregular por reabsorção cementária e dentinária ativa com marcada presença de clastos. Em 14 espécimes detectamos algumas áreas com reabsorção sendo 
pretensamente reparadas pela deposição de material cementóide irregularmente depositado.

Na região apical cocos e bacilos Gram-positivos e Gram-negativos livres, em colônias e biofilmes estavam distribuídos nas superfícies irregulares dos tecidos cementário e dentinário. Em quatro espécimes com necrose e um espécime com pulpite detectou-se bactérias na região apical intratubular.

Em um espécime pôde-se observar no ápice de uma das raízes de molar, que a polpa comunicava-se com o periodonto apical por meio de três forames apicais em linha, também envolvidos pela reabsorção cementodentinária. 


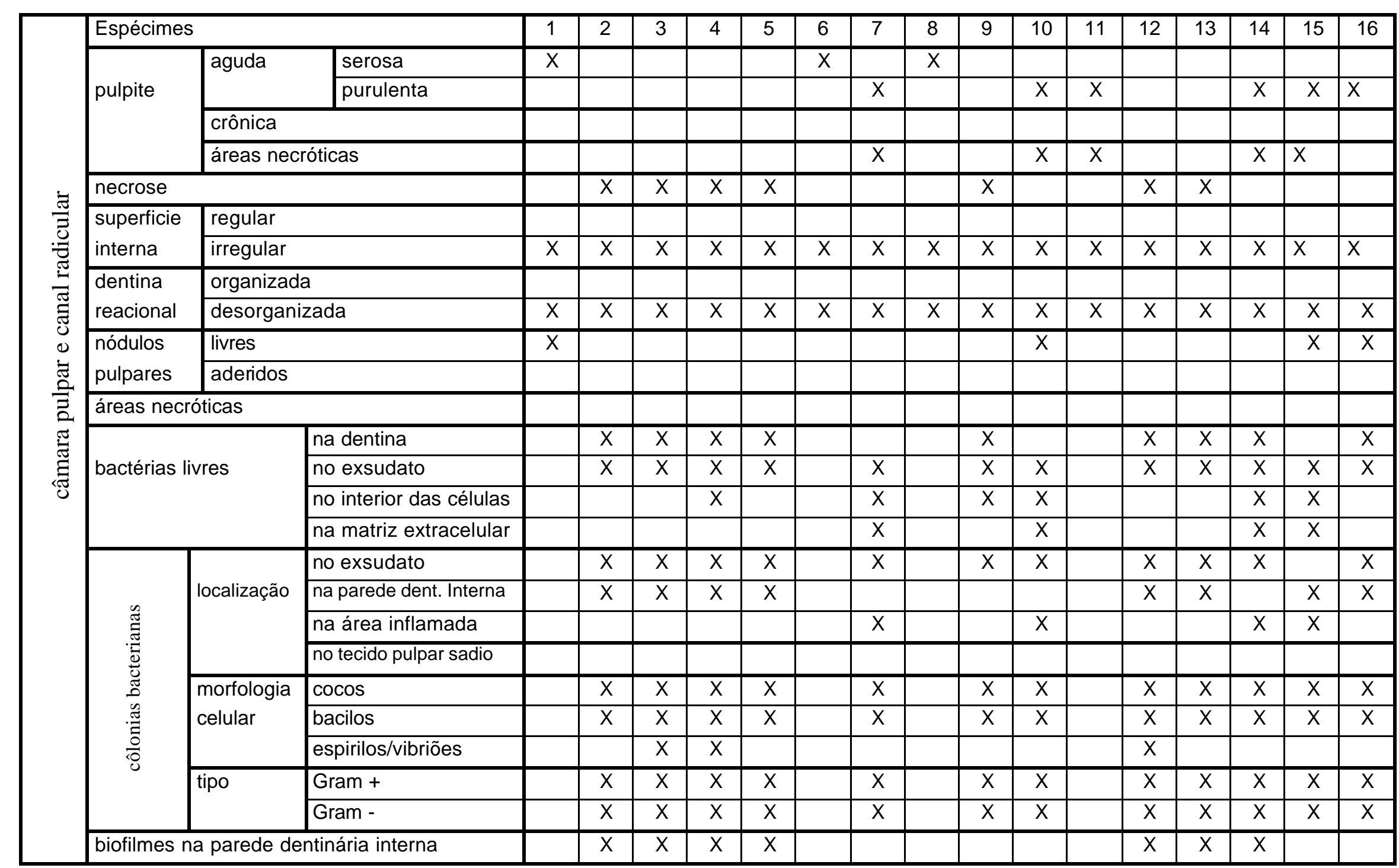

FIGURA 4 - Distribuição dos achados microscópicos morfológicos da câmara pulpar e do canal radicular, em cortes transversais, corados pelas técnicas da hematoxilina-eosina e de Brown e Brenn 


\begin{tabular}{|c|c|c|c|c|c|c|c|c|c|c|c|c|c|c|c|c|c|c|c|}
\hline \multirow{5}{*}{\begin{tabular}{|l|} 
\\
\end{tabular}} & \multicolumn{3}{|l|}{ Espécimes } & 1 & 2 & 3 & 4 & 5 & 6 & 7 & 8 & 9 & 10 & 11 & 12 & 13 & 14 & 15 & 16 \\
\hline & \multirow{4}{*}{$\begin{array}{l}\text { túbulos } \\
\text { dentinários }\end{array}$} & \multicolumn{2}{|l|}{ preservados } & $\mathrm{X}$ & $\mathrm{X}$ & $\mathrm{X}$ & $\mathrm{X}$ & $\mathrm{X}$ & $\mathrm{X}$ & $\mathrm{X}$ & $\mathrm{X}$ & $\mathrm{X}$ & $\mathrm{X}$ & $\mathrm{X}$ & $\mathrm{X}$ & $\mathrm{X}$ & $\mathrm{X}$ & $\mathrm{X}$ & $\bar{X}$ \\
\hline & & \multicolumn{2}{|l|}{ dilatados } & & & & & & & & & & & & & & & & \\
\hline & & \multicolumn{2}{|l|}{ varicosos } & & & & & & & & & & & & & & & & \\
\hline & & \multicolumn{2}{|c|}{ focos de liquefação } & & & & & & & & & & & & & & & & \\
\hline \multirow{20}{*}{. } & \multirow{20}{*}{. } & \multicolumn{2}{|l|}{ presentes } & & $\mathrm{X}$ & $\mathrm{X}$ & $\mathrm{X}$ & $\mathrm{X}$ & & & & $\mathrm{X}$ & & & $\mathrm{X}$ & $\mathrm{X}$ & $\mathrm{X}$ & & $\bar{X}$ \\
\hline & & \multicolumn{2}{|l|}{ ausentes } & $\mathrm{X}$ & & & & & $\mathrm{X}$ & $X$ & $\mathrm{X}$ & & $\mathrm{X}$ & $\mathrm{X}$ & & & & $\mathrm{X}$ & \\
\hline & & \multirow{3}{*}{$\begin{array}{l}\text { morfologia } \\
\text { celular }\end{array}$} & $\operatorname{cocos}$ & & $\mathrm{X}$ & $\mathrm{X}$ & $\mathrm{X}$ & $\mathrm{X}$ & & & & $\mathrm{X}$ & & & $\mathrm{X}$ & $\mathrm{X}$ & $\mathrm{X}$ & & $\mathrm{X}$ \\
\hline & & & bacilos & & $\mathrm{X}$ & $\mathrm{X}$ & $\mathrm{X}$ & $\mathrm{X}$ & & & & $\mathrm{X}$ & & & $\mathrm{X}$ & $\mathrm{X}$ & $\mathrm{X}$ & & $\mathrm{X}$ \\
\hline & & & espirilos/vibriões & & & & & & & & & & & & & & & & \\
\hline & & \multirow[t]{2}{*}{ tipo } & Gram + & & $\bar{X}$ & $\mathrm{X}$ & $\bar{X}$ & $\bar{X}$ & & & & $\bar{X}$ & & & $\bar{X}$ & $\mathrm{X}$ & $\mathrm{X}$ & & $\mathrm{X}$ \\
\hline & & & Gram - & & $\mathrm{X}$ & $\mathrm{X}$ & $\mathrm{X}$ & $\mathrm{X}$ & & & & $\mathrm{X}$ & & & $\mathrm{X}$ & $\mathrm{X}$ & $\mathrm{X}$ & & $\mathrm{X}$ \\
\hline & & \multicolumn{2}{|l|}{ livres } & & & $\mathrm{X}$ & $\mathrm{X}$ & $\mathrm{X}$ & & & & & & & $\mathrm{X}$ & $\mathrm{X}$ & $\mathrm{X}$ & $\mathrm{X}$ & $\mathrm{X}$ \\
\hline & & \multicolumn{2}{|c|}{ em colônias externas } & & & $\mathrm{X}$ & $\mathrm{X}$ & $\mathrm{X}$ & & & & & & & $\mathrm{X}$ & $\mathrm{X}$ & $\mathrm{X}$ & $\mathrm{X}$ & $\mathrm{X}$ \\
\hline & & \multicolumn{2}{|c|}{ biofilmes microbianos externos } & & & $\mathrm{X}$ & $\mathrm{X}$ & $\mathrm{X}$ & & & & & & & & & & & \\
\hline & & \multirow{3}{*}{$\begin{array}{l}\text { densidade } \\
\text { Intratubular }\end{array}$} & Leve & & $\mathrm{X}$ & & $\mathrm{X}$ & $\mathrm{X}$ & & & & $\mathrm{X}$ & & & $\mathrm{X}$ & $\mathrm{X}$ & $\mathrm{X}$ & & \\
\hline & & & moderada & & & $\mathrm{X}$ & & & & & & & & & & & & & $\mathrm{X}$ \\
\hline & & & intensa & & & & & & & & & & & & & & & & \\
\hline & & \multirow{3}{*}{$\begin{array}{l}\text { localização } \\
\text { na espessura }\end{array}$} & 1/3 pulpar & & $\mathrm{X}$ & $\mathrm{X}$ & $\mathrm{X}$ & $\mathrm{X}$ & & & & $X$ & & & $\mathrm{X}$ & $\mathrm{X}$ & $\mathrm{X}$ & & $\mathrm{X}$ \\
\hline & & & 1/3 médio & & & $\mathrm{X}$ & & & & & & & & & & & & & $\mathrm{X}$ \\
\hline & & & 1/3 superficial & & & & & & & & & & & & & & & & \\
\hline & & \multirow{4}{*}{$\begin{array}{l}\text { localização } \\
\text { topográfica }\end{array}$} & no soalho da câmara & & & & & & & & & & & & & & & & \\
\hline & & & na parede lateral & & $\mathrm{X}$ & $\mathrm{X}$ & $\mathrm{X}$ & $\mathrm{X}$ & & & & $\mathrm{X}$ & & & $\mathrm{X}$ & $\mathrm{X}$ & $\mathrm{X}$ & & $\mathrm{X}$ \\
\hline & & & na dentina radicular & & & $\mathrm{X}$ & $\mathrm{X}$ & $\mathrm{X}$ & & & & $\mathrm{X}$ & & & $\mathrm{X}$ & $\mathrm{X}$ & $\mathrm{X}$ & & $\mathrm{X}$ \\
\hline & & & na dentina apical & & & $X$ & $\mathrm{X}$ & $X$ & & & & & & & $X$ & $\mathrm{X}$ & $X$ & & $X$ \\
\hline
\end{tabular}

FIGURA 5 - Distribuição dos achados microscópicos morfológicos das bactérias Gram-positivas e Gram-negativas nos túbulos dentinários, em cortes transversais, corados pelas técnicas da hematoxilina-eosina e de Brown e Brenn 


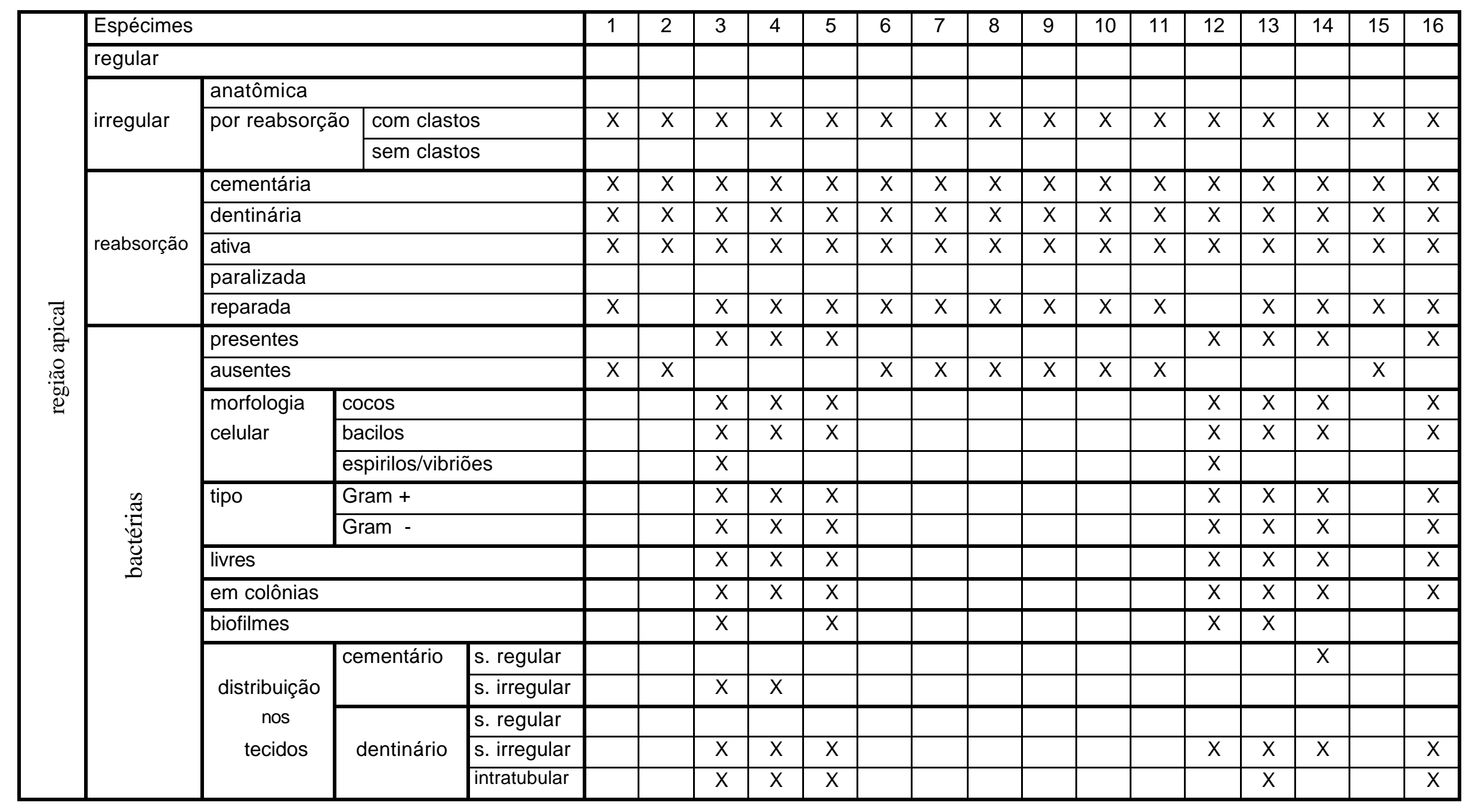

FIGURA 6 - Distribuição dos achados microscópicos morfológicos da região apical e das bactérias Gram-positivas e Gram-negativas, em cortes transversais, corados pelas técnicas da hematoxilina-eosina e de Brown e Brenn 
ILUSTRAÇÕES FOTOGRÁFICAS 


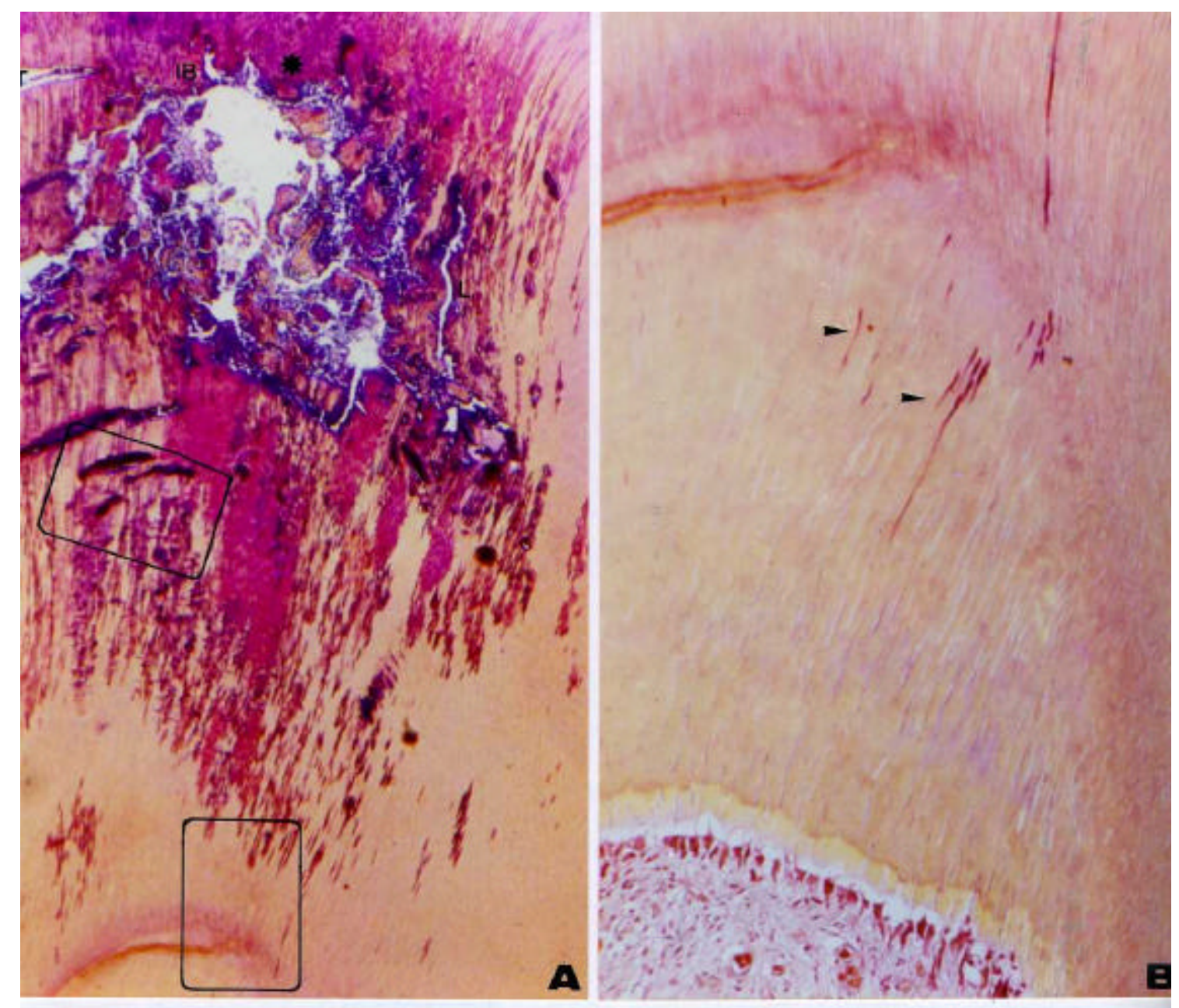

FIGURA 7 - Cárie dentária revelando zonas de destruição e desorganização avançada de dentina (*) e zona de destruição e desorganização inicial. Na zona de invasão bacteriana (IB) predominantemente Gram-negativa, destaca-se os focos de liquefação longitudinais (L) e transversais (T). Bactérias pioneiras e Gram-negativas são visualizadas na dentina reacional destacadas em $B$ (setas), onde se observa camada odontoblástica e polpa preservadas. B.B.; aumento original: $A=16 X ; B=40 X$ ) 


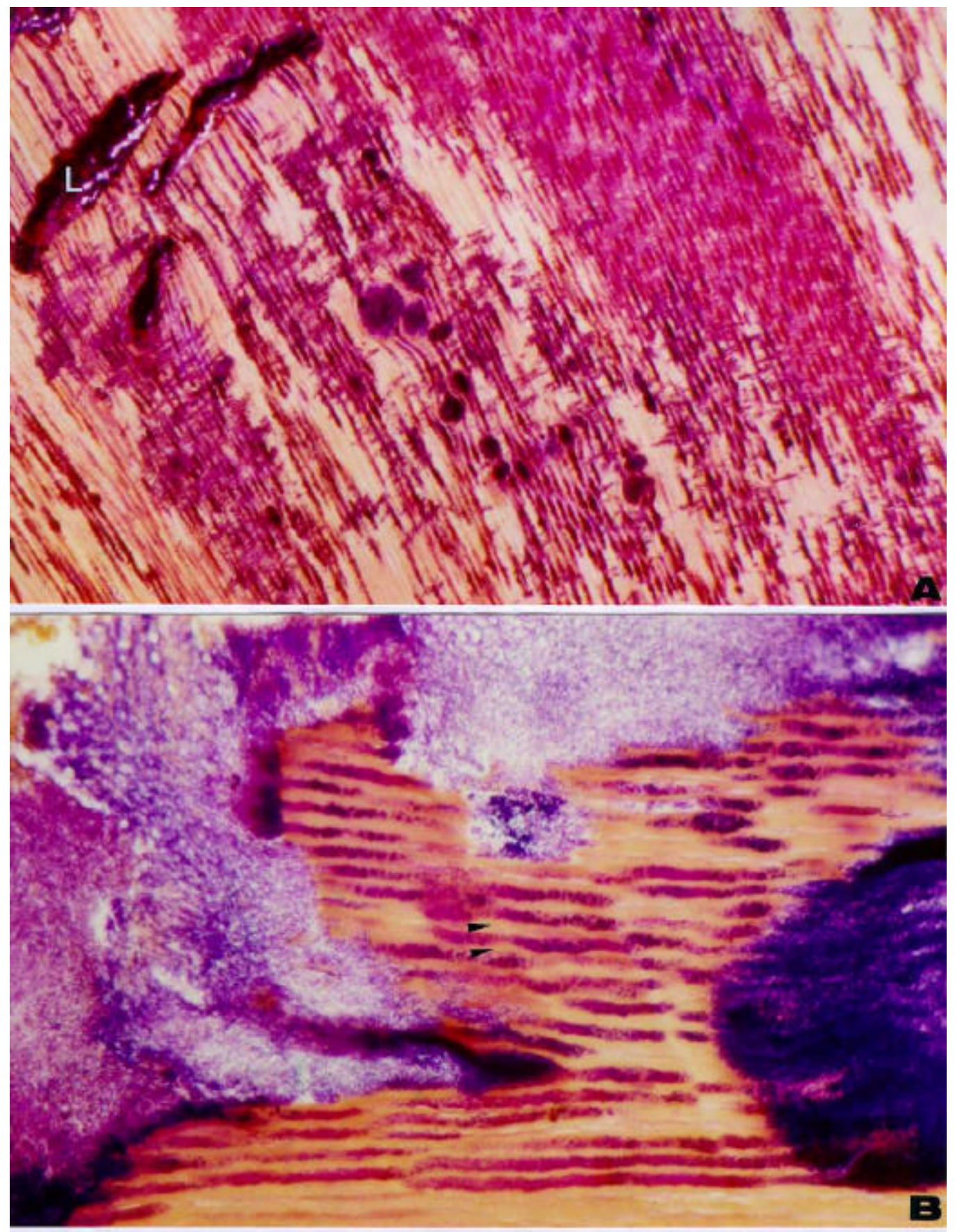

FIGURA 8 - Bactérias predominantemente Gram-negativas localizadas nos túbulos dentinários; as Gram-positivas predominam nos focos avançados de liquefação (L). Na cárie de dentina, a mesma da figura anterior, destaca-se as varicosidades ou formação em rosário decorrente da ação lítica e focal das bactérias no interior dos túbulos (setas). (B.B.; aumento original: $A=40 X ; B=160 X$ ) 

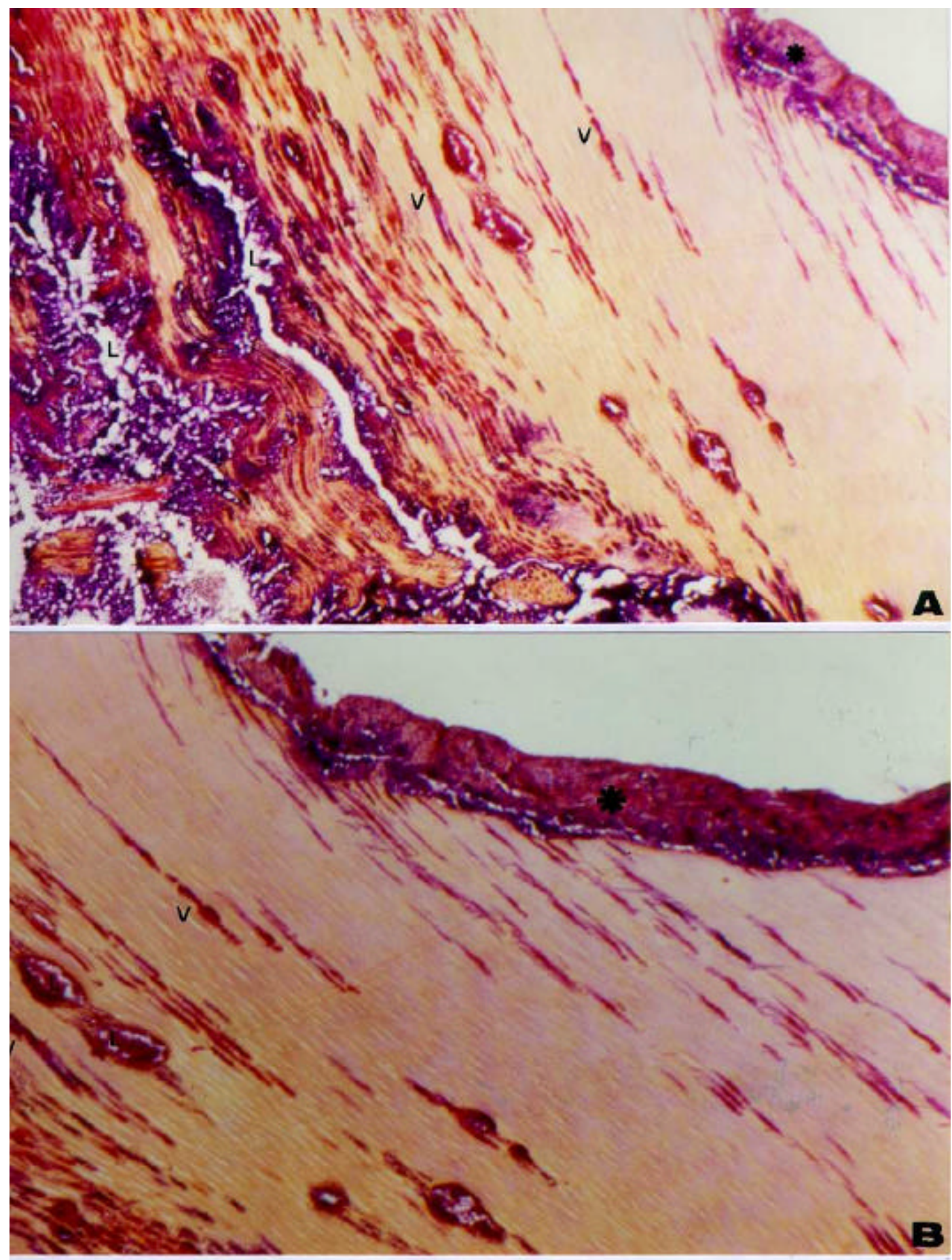

FIGURA 9 - Biofilme microbiano na superfície dentinária em área de cárie na qual se observa áreas de intensa desorganização (*) predominando bactérias Gram-positivas e infiltração de bactérias Gram-negativas, inclusive nos focos de liquefação pequenos $(L)$ e nas varicosidades $(V)$. (B.B.; aumento original: $A$ e $B=40 X$ ) 


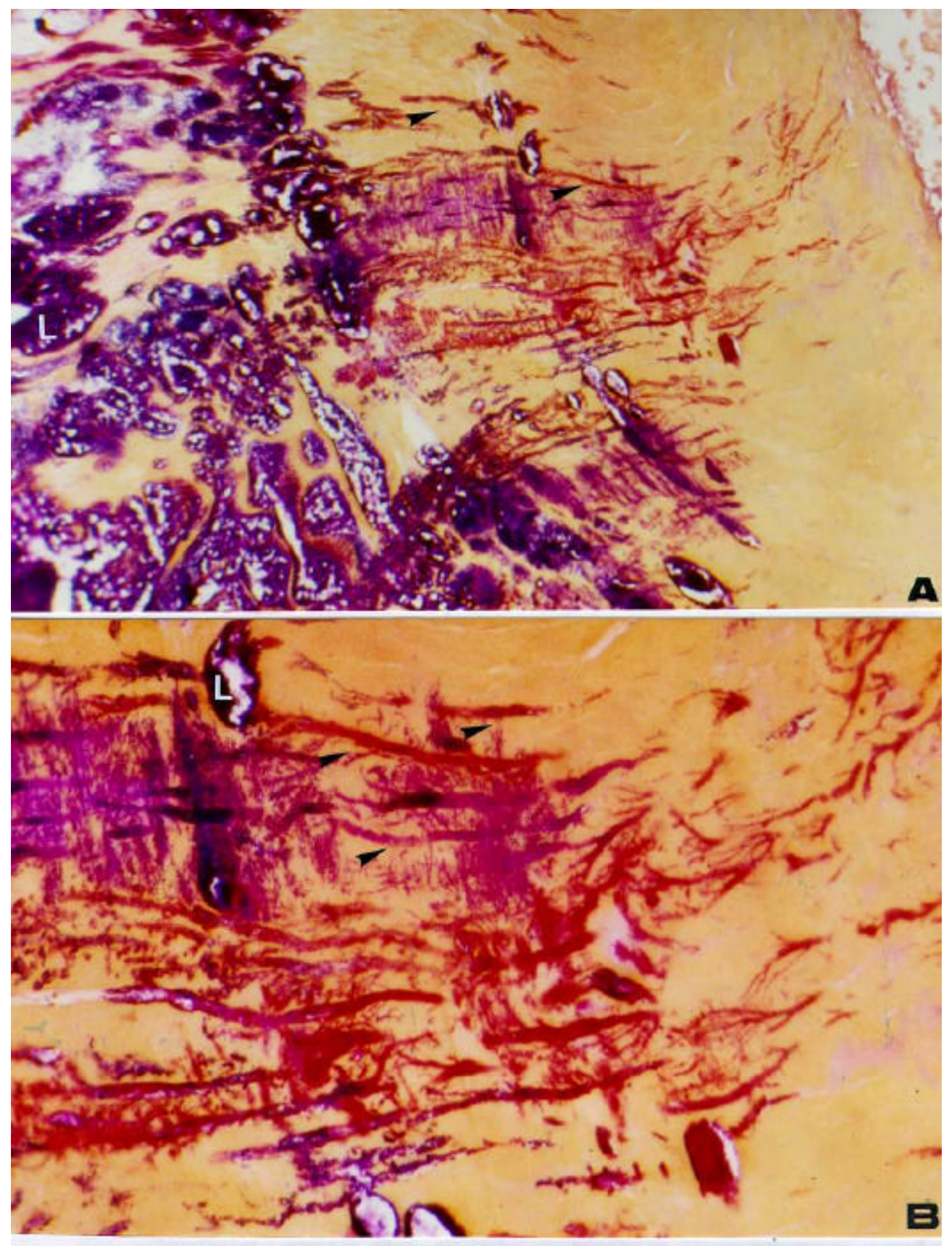

FIGURA 10 - Infiltração bacteriana em dentina de decíduo com necrose pulpar. Nos focos de liquefação (L) predominam bactérias Gram-positivas; nos túbulos dentinários e nas suas ramificações laterais predominam bactérias Gram-negativas (setas). (B.B.; aumento original: $A=40 X ; B=160 X)$ 


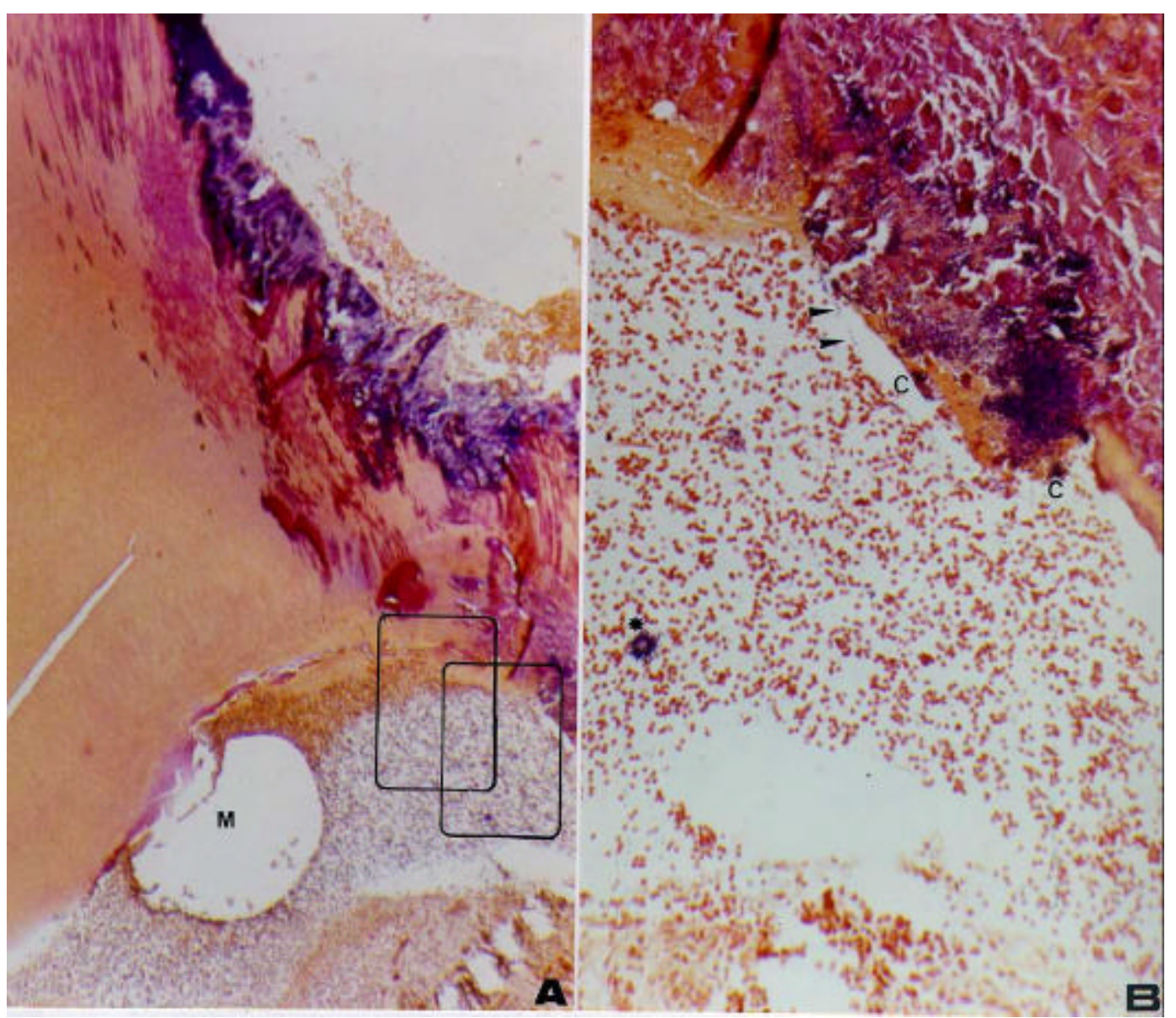

FIGURA 11 - Dente decíduo com cárie relacionada diretamente com a polpa dentária em intenso processo inflamatório com microabscesso (M). Destaca-se em B, a presença de bactérias planctônicas (setas) e colônias diretamente em contato com a polpa interior da polpa (*). Em C, além das observações

(C) e no 


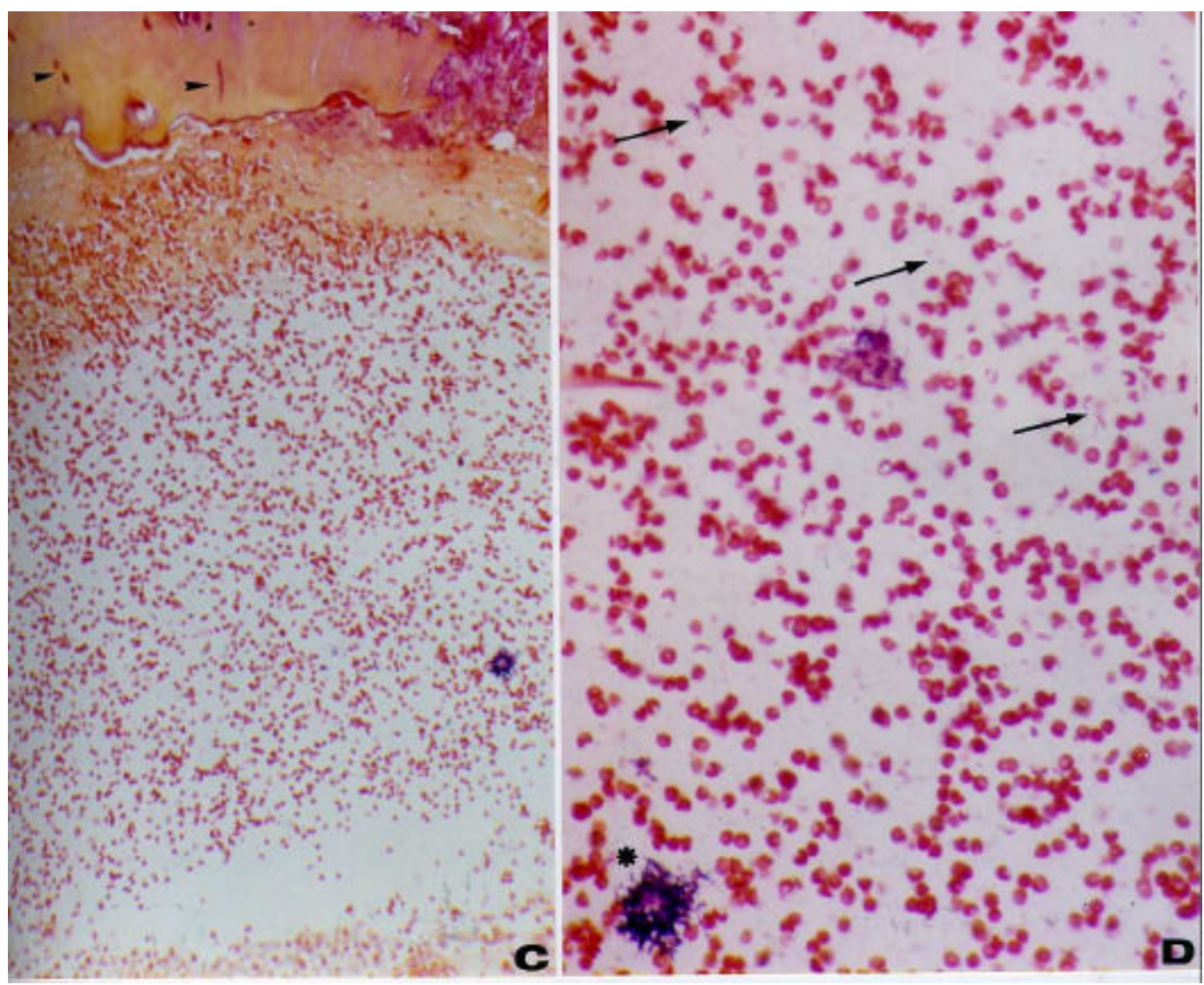

... anteriores, destaca-se a chegada de bactérias Gram-negativas à polpa via túbulos dentinários (setas menores). Em D, colônias bacterianas intrapulpares em maior magnitude (*) e numerosas bactérias planctônicas (setas) de permeio ao exsudato e infiltrado inflamatório. (B.B.; aumento original: $A=16 X$; B e $C=40 X$; $D=100 X$ ) 

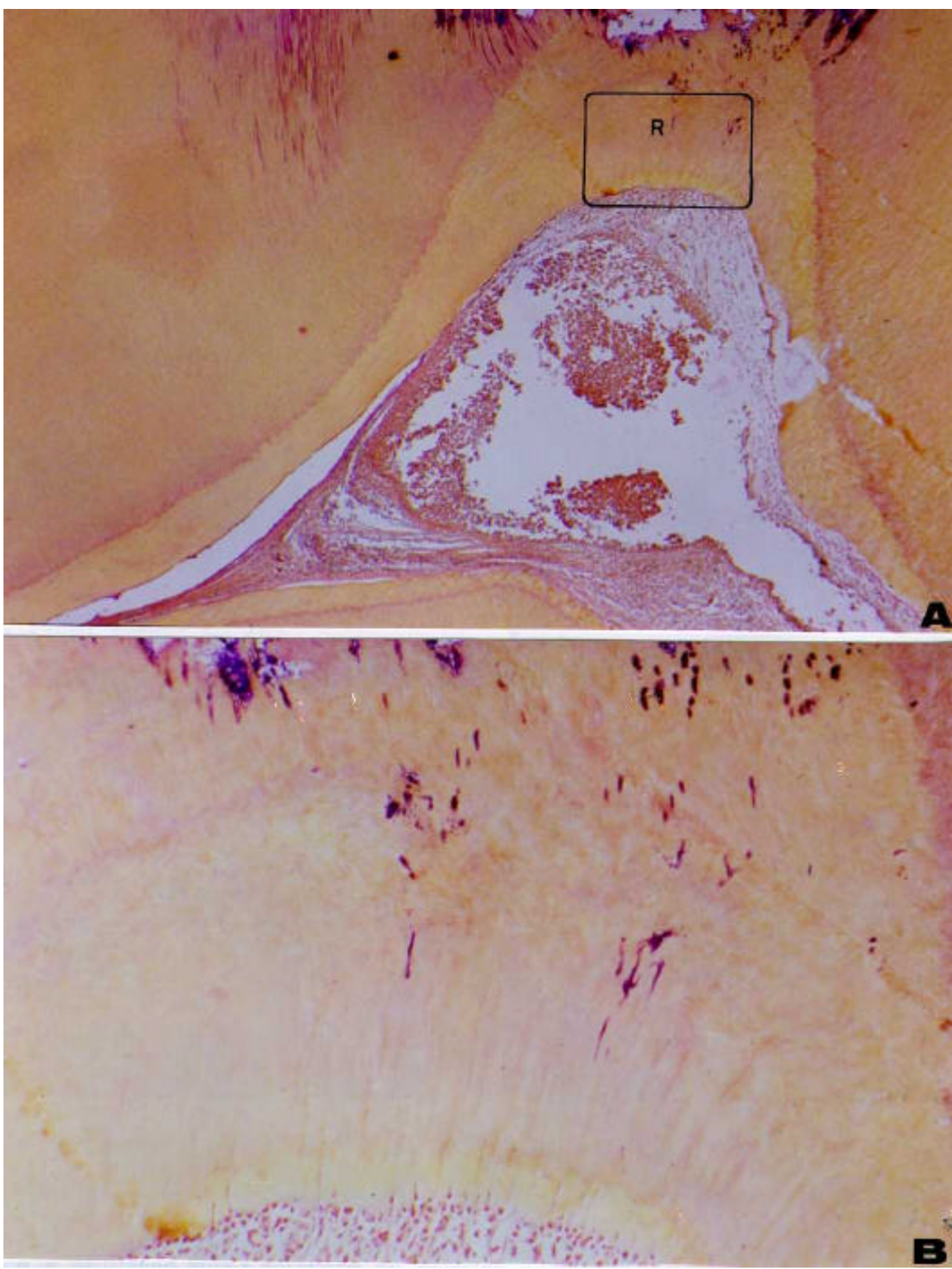

FIGURA 12 - Infiltração bacteriana em túbulos de dentina primária e reacional (R) em dentes decíduos com pulpite. Em B, nota-se a preservação discretamente desorganizada da camada odontoblástica. A dentina reacional em $\mathrm{C}$ e $\mathrm{D}$ acha-se avançada em 

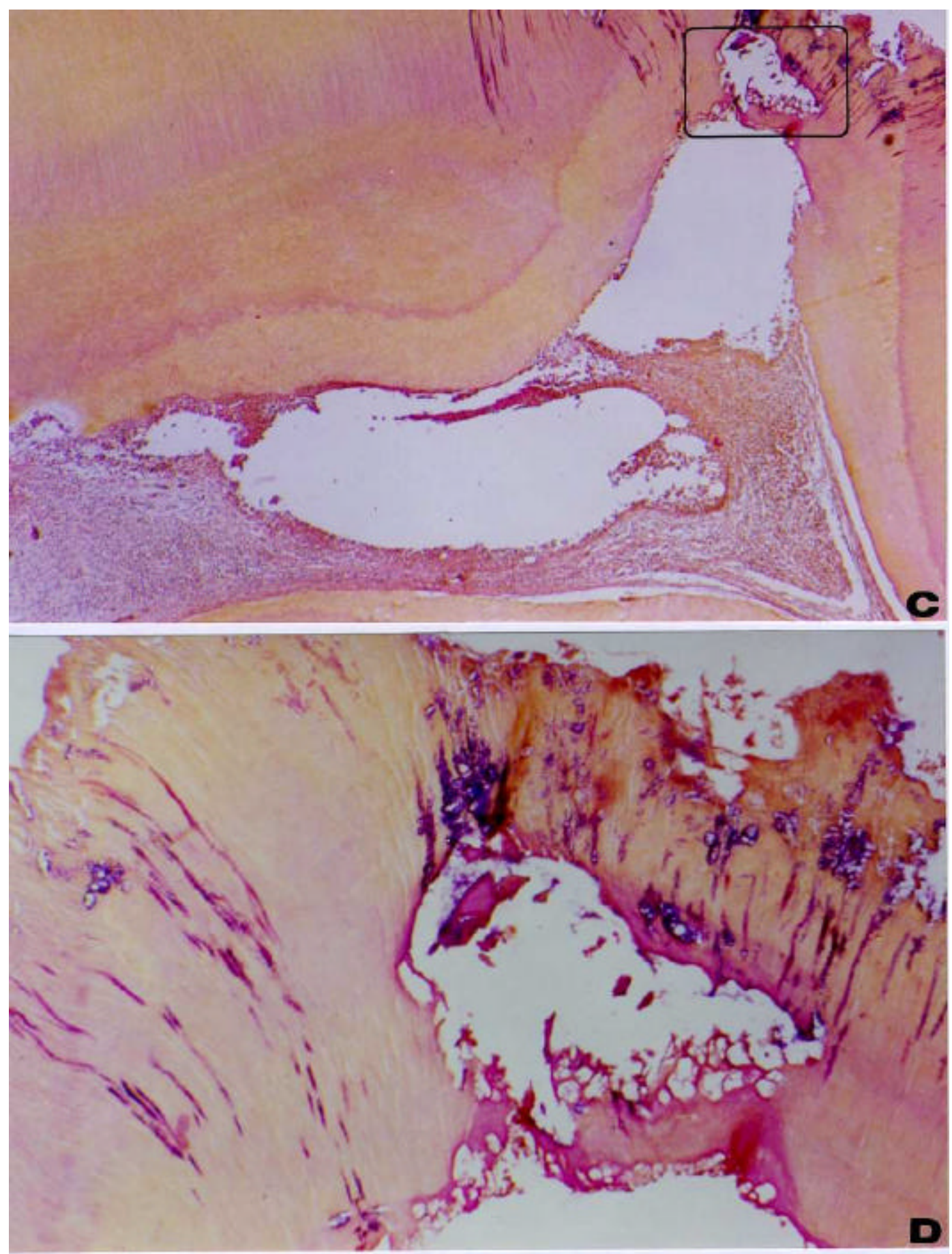

... sua desorganização e destruição, inclusive com focos de liquefação longitudinais e transversais. Em $C$ e $D$ o tecido correspondente ao corno pulpar apresenta-se todo destruído e a pulpite subjacente mostra-se abscedida. (B.B.; aumento original: A e $C=16 X ; B=100 X$ e $D=40 X$ ) 


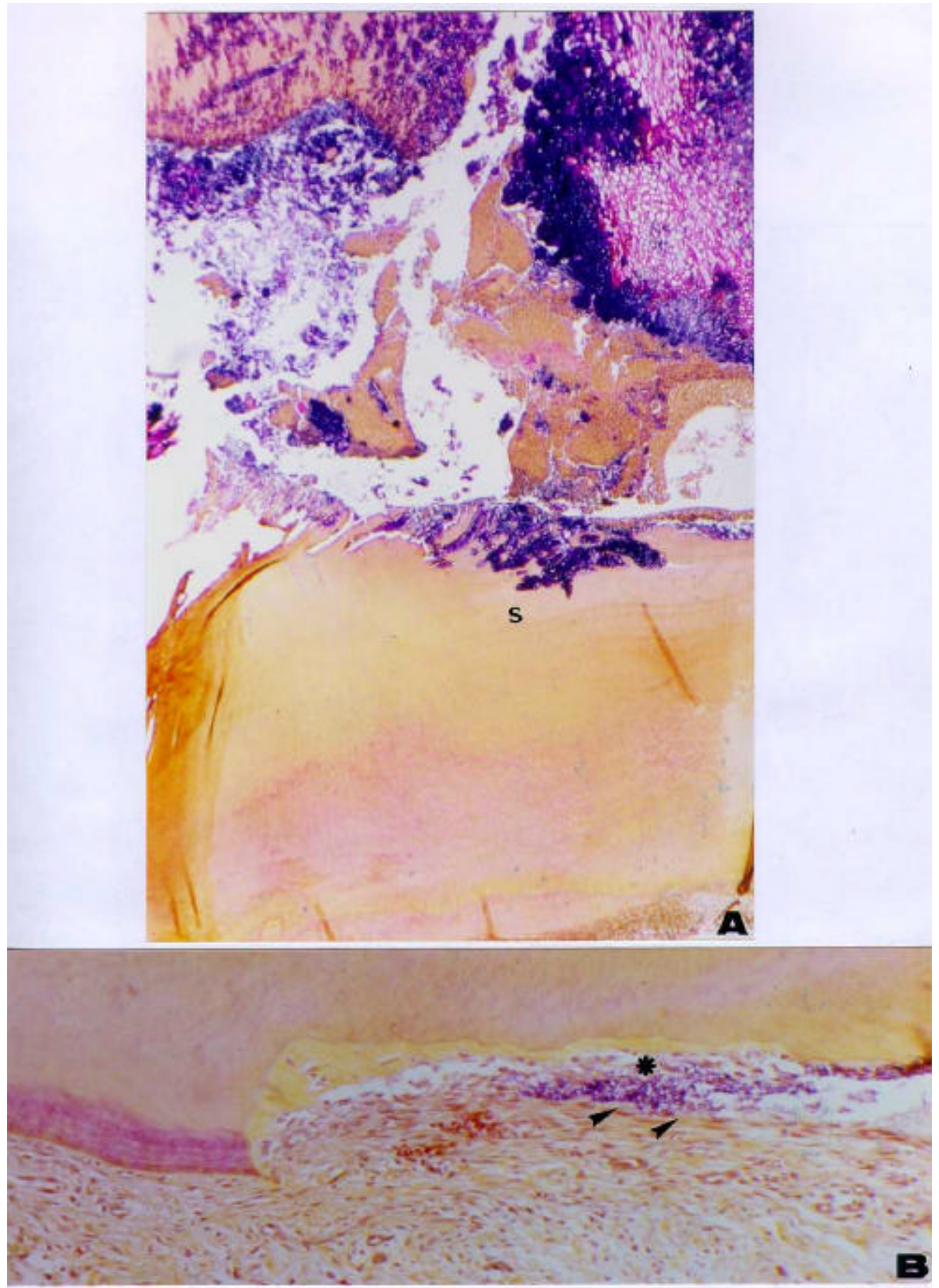

FIGURA 13 - Soalho da câmara pulpar (S) de molar decíduo com necrose pulpar na qual observa-se, em $\mathrm{A}$, a penetração bacteriana na estrutura dentinária promovendo a possibilidade dos produtos ou corpos microbianos chegarem até a face externa correspondente, como se vê em $B$ (setas), associadas a reabsorção cementodentinária do mesmo dente (*). (B.B.; aumento original: $A=16 X$; $B$ $=40 \mathrm{X})$ 


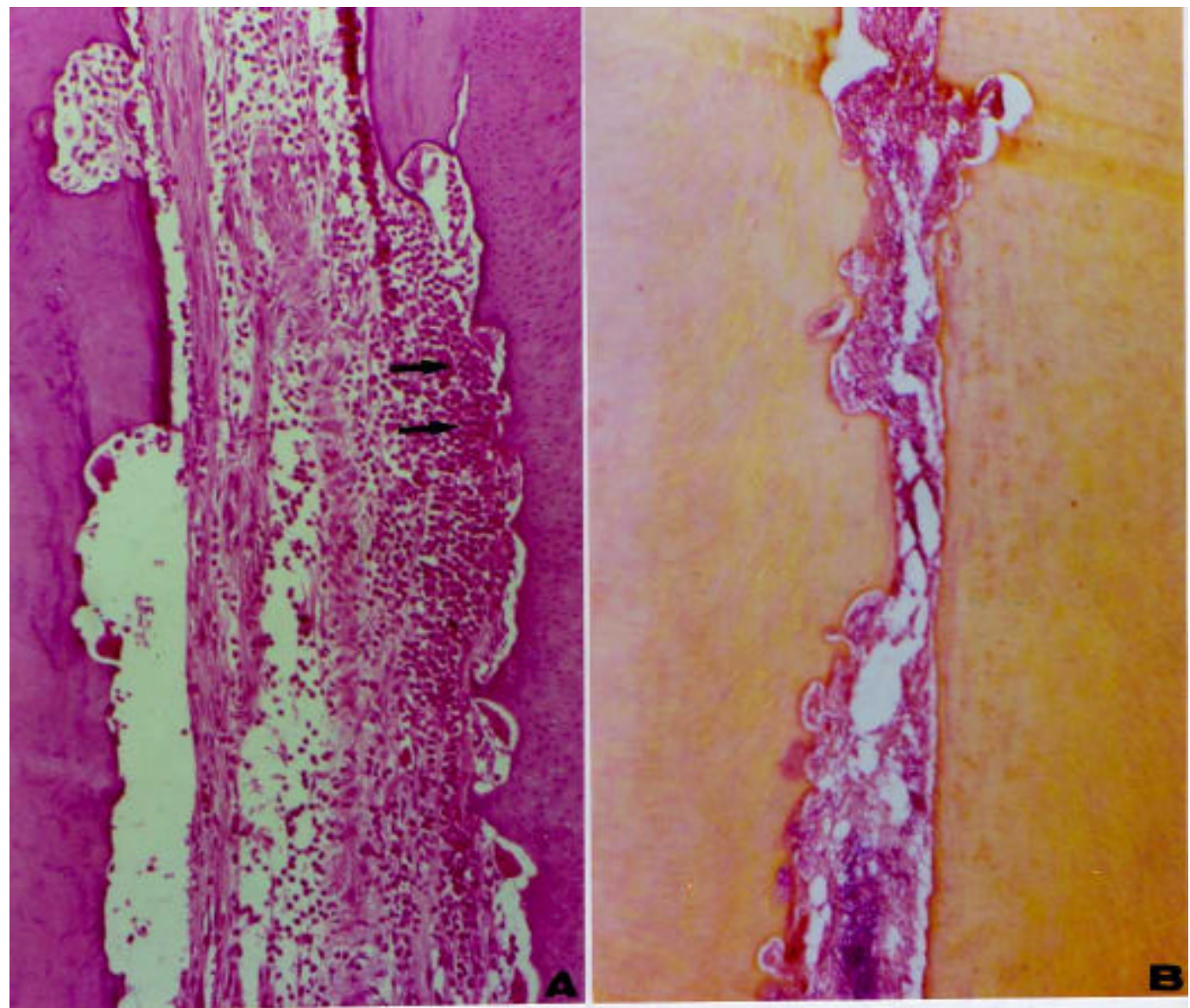

FIGURA 14 - Reabsorção interna de dentes decíduos: em A com pulpite crônica, em B com necrose pulpar. Em A, destaca-se as BMU ou unidades osteorremodeladoras (setas) e lacunas de Howship. Em $B$, após a necrose pulpar e invasão bacteriana, as colônias e biofilmes microbianos se alojam nas anfractuosidades decorrentes da reabsorção interna agora inativa. (H.E. e B.B.; aumento original: $A$ e $B=40 X$ ) 


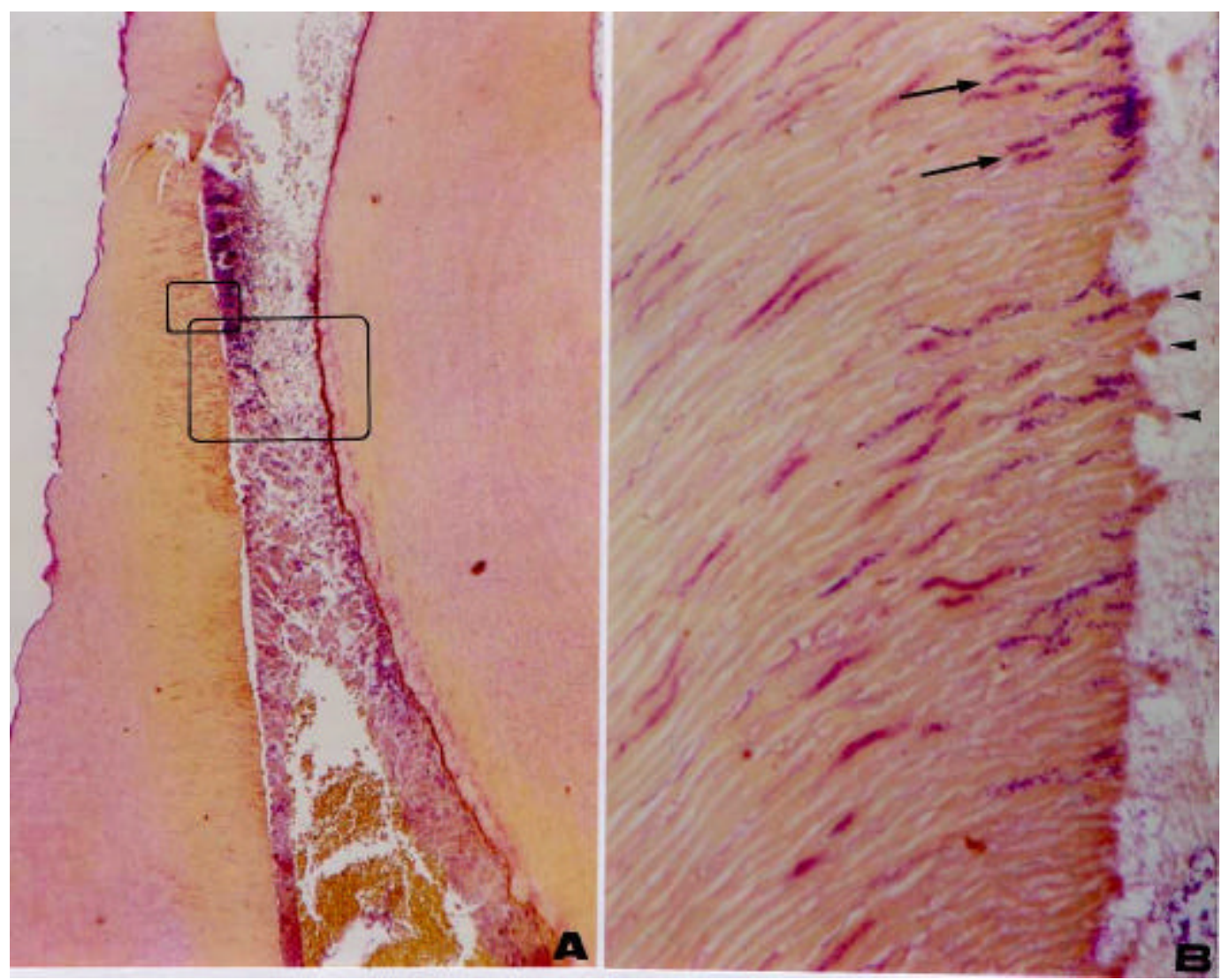

FIGURA 15 - Canal radicular de molar decíduo, com necrose pulpar, preenchido parcialmente por bactérias planctônicas, colônias e biofilmes microbianos nas superfícies internas. Em A, destaca-se a associação da penetração bacteriana nos túbulos dentinários e sua íntima relação com áreas externas de reabsorção. Em B, nota-se que em algumas regiões, certos segmentos tubulares, os mais próximos do canal, predominam bactérias Gram-positivas (setas), em outras 

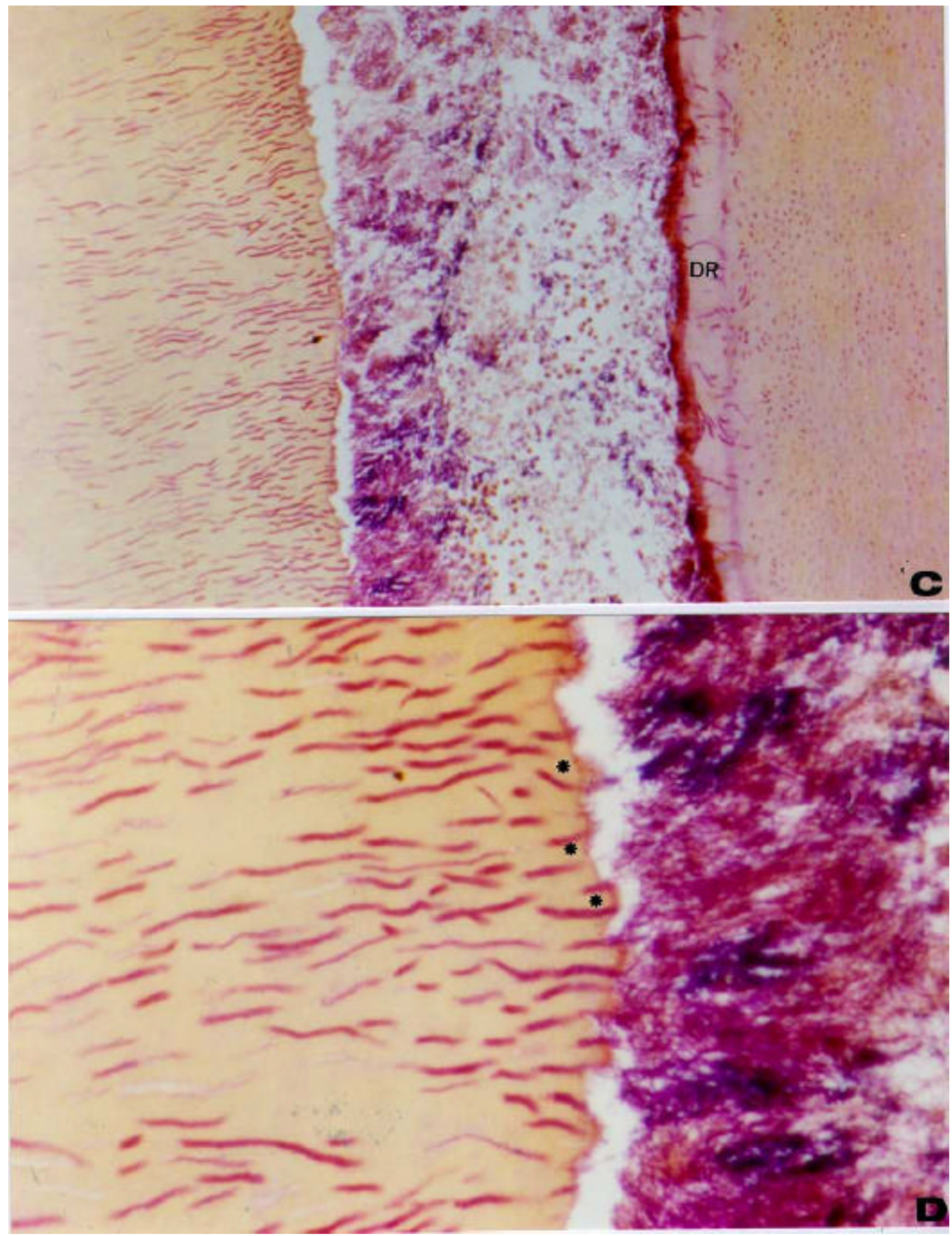

.. predominantemente tem-se bactérias Gram-negativas como se destaca em $D(*)$. Em $C$, ressalta-se que em algumas superfícies houve tempo para formação de dentina reacional (DR), em outras superfícies a pré-dentina foi dissolvida permanecendo ainda identificável as calcoferitas aderidas, como ressalta-se mais ainda em B (setas menores). (B.B.; aumento original: $A=16 X$; $B$ e $D=$ 100X; $C=40 X)$ 


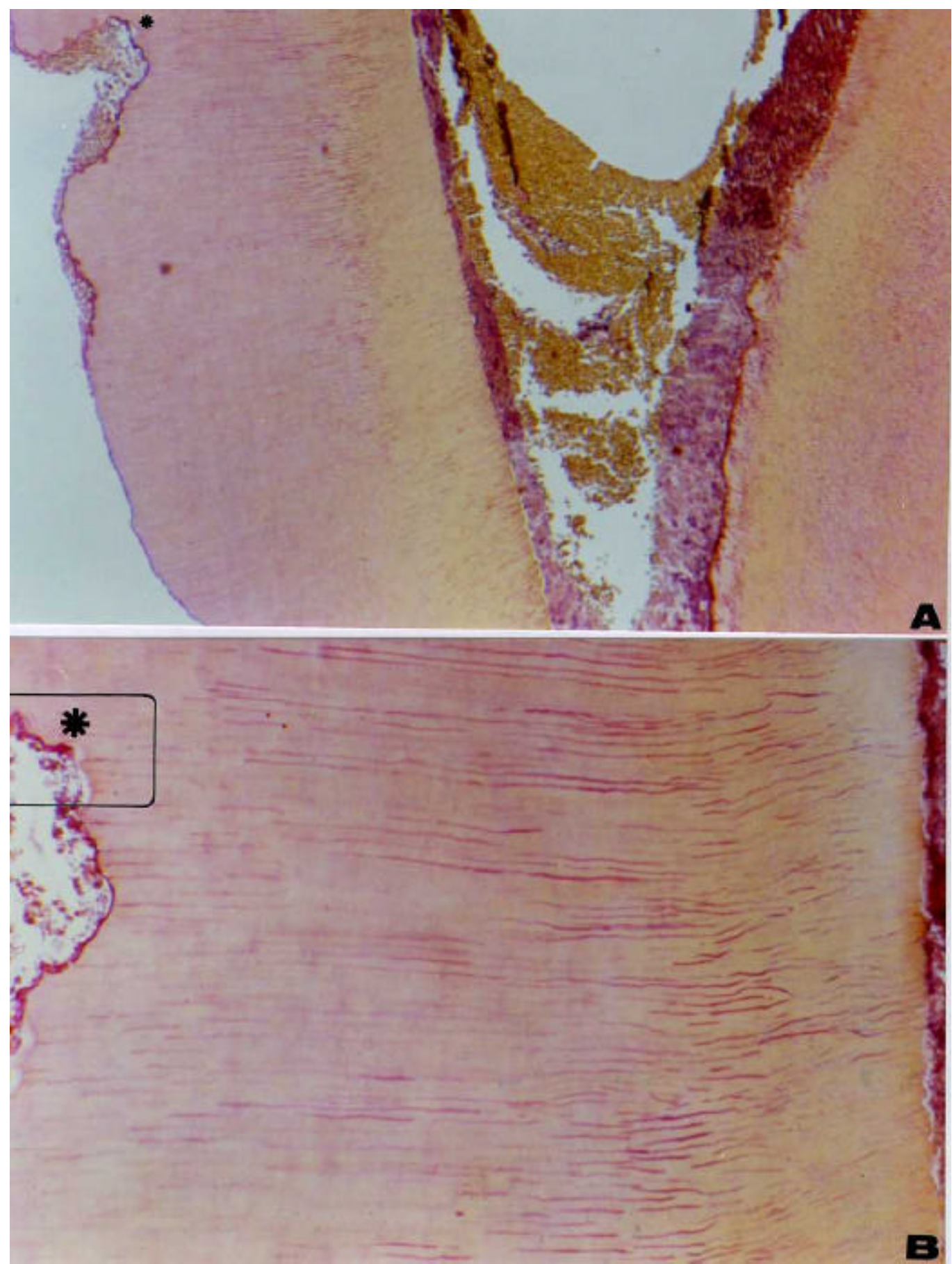

FIGURA 16 - Dente decíduo com necrose pulpar e rico componente bacteriano no canal radicular. Em A e B, pode-se notar, em visão panorâmica, a relação do componente bacteriano intratubular com a área externa em reabsorção (*). Nas lacunas da reabsorção externa têm-se franca presença de bactérias 

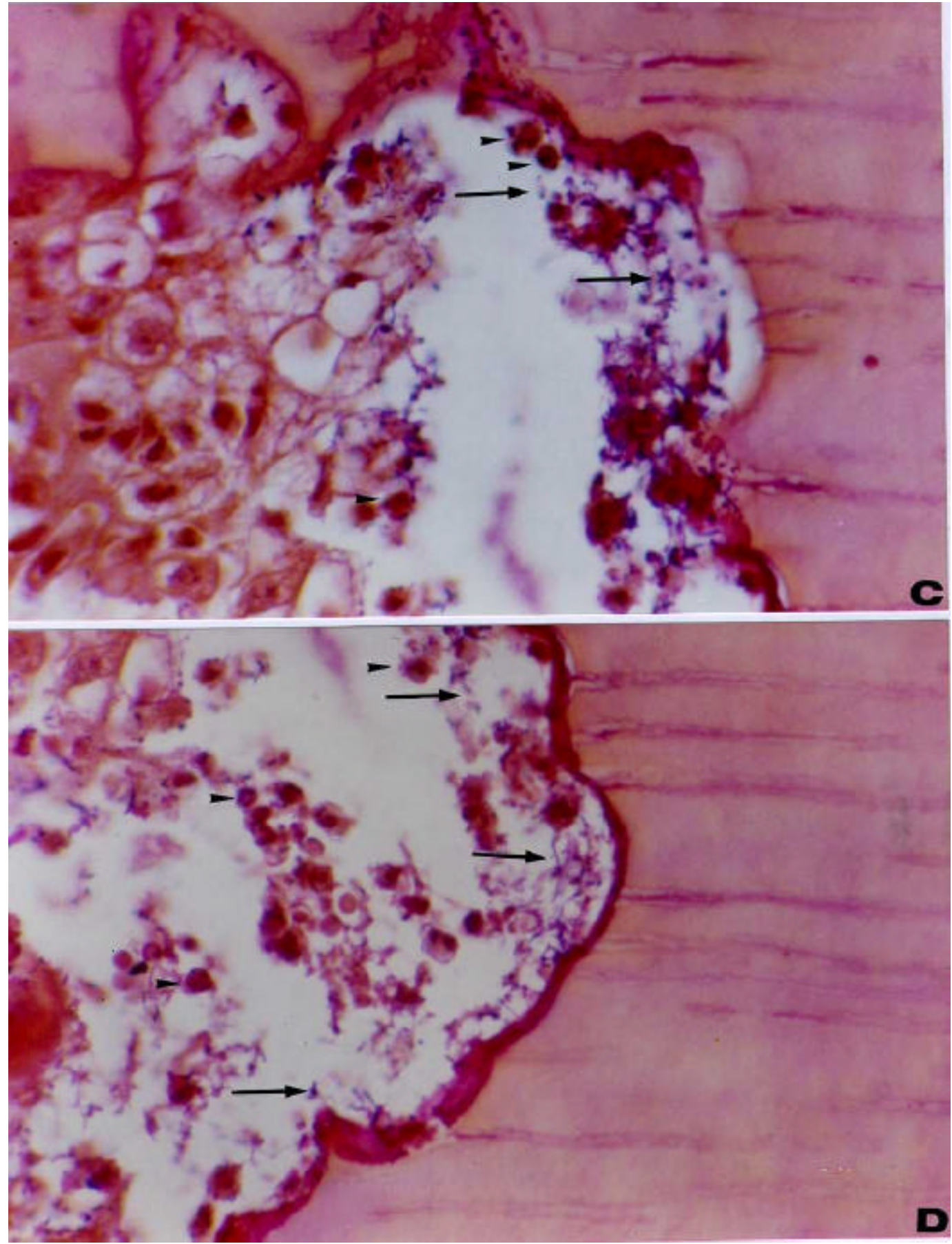

... planctônicas Gram-positivas (setas) nas lacunas de Howship associadas à presença de bactérias Gram-negativas nos túbulos dentinários. Em algumas células macrofágicas, têm-se bactérias no interior do citoplasma (setas menores). (B.B.; aumento original: $A=16 X$; $B=40 X$; $C$ e $D=160 X$ ) 

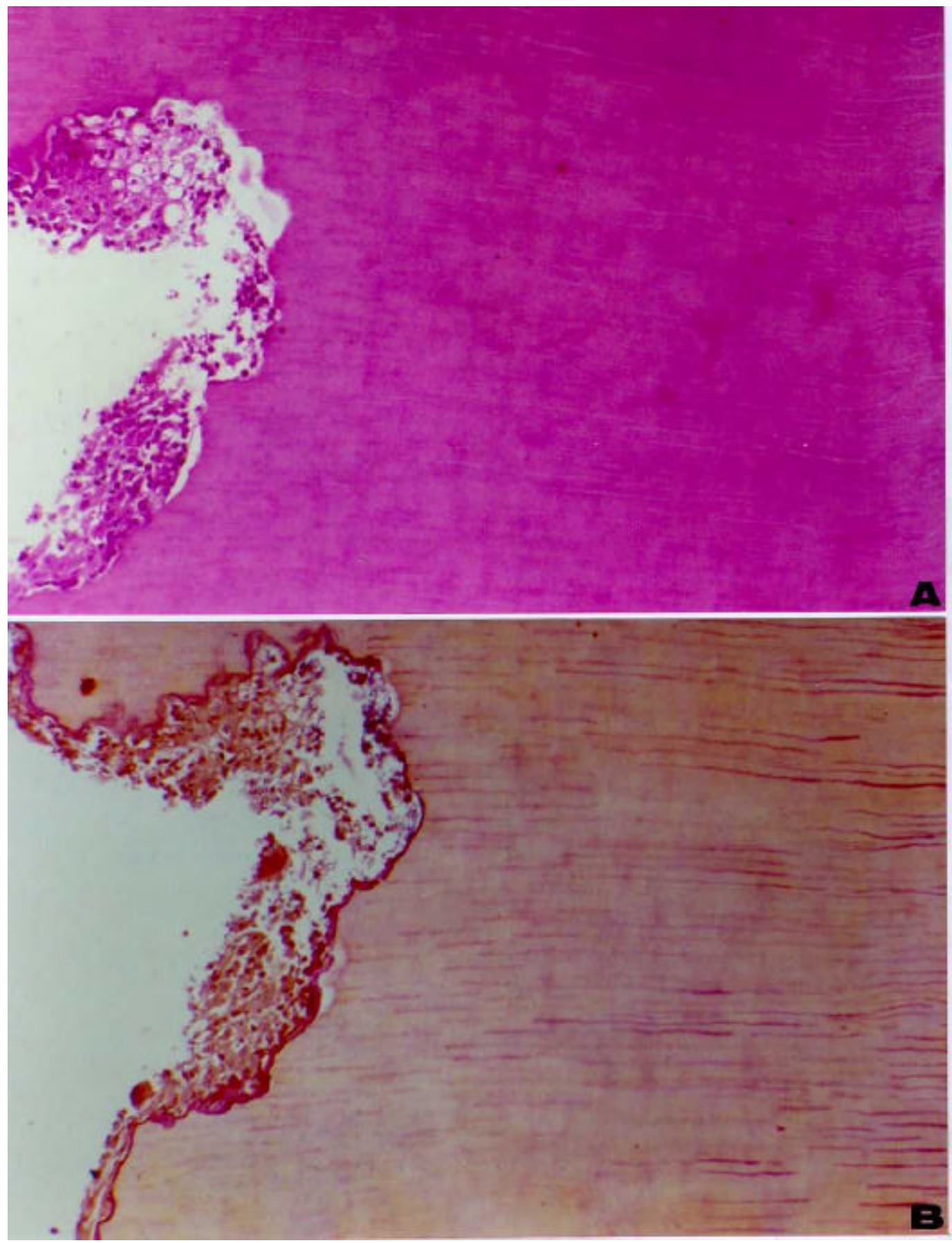

FIGURA 17 - Ilustrações comparativas do mesmo campo microscópico corados pela técnica da hematoxilina e eosina (em A) e de Brown e Brenn (em B). Destaca-se a efetividade da técnica Brown e Brenn na evidenciação das bactérias intratubulares nas lacunas de Howship; como se tem na Figura 16. (H.E.; B.B.; aumento original: A e B = 40X) 


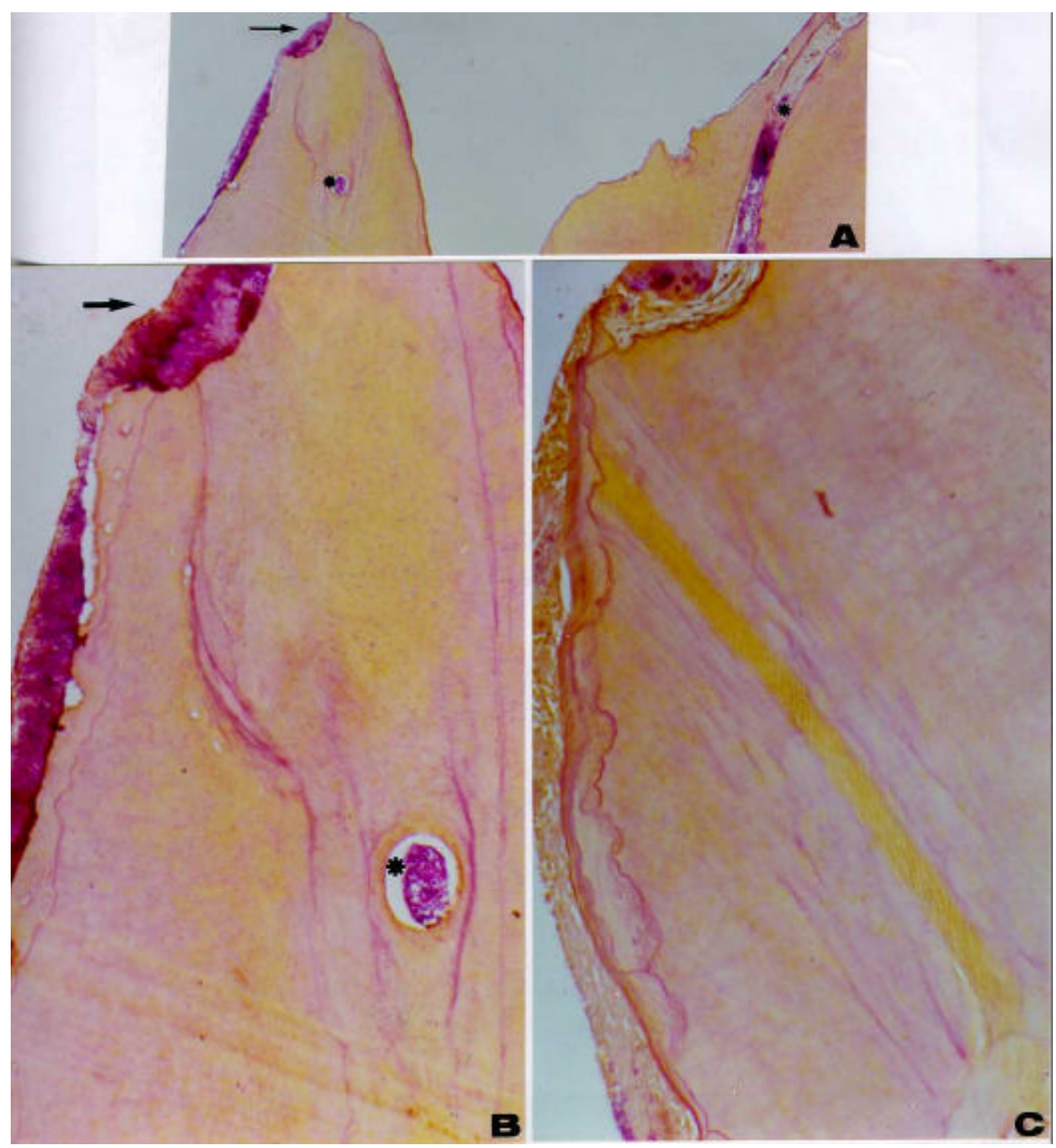

FIGURA 18 - Ápices de dentes decíduos com necrose pulpar revelando colonização da superfície por biofimes microbianos (setas), especialmente nas lacunas de Howship que representam anfractuosidades importantes para a persistência bacteriana na estrutura dentária. Também observa-se componente bacteriano na luz dos canais radiculares (*). (B.B.; aumento original: $A=10 X$; $B$ e $C=40 X)$ 

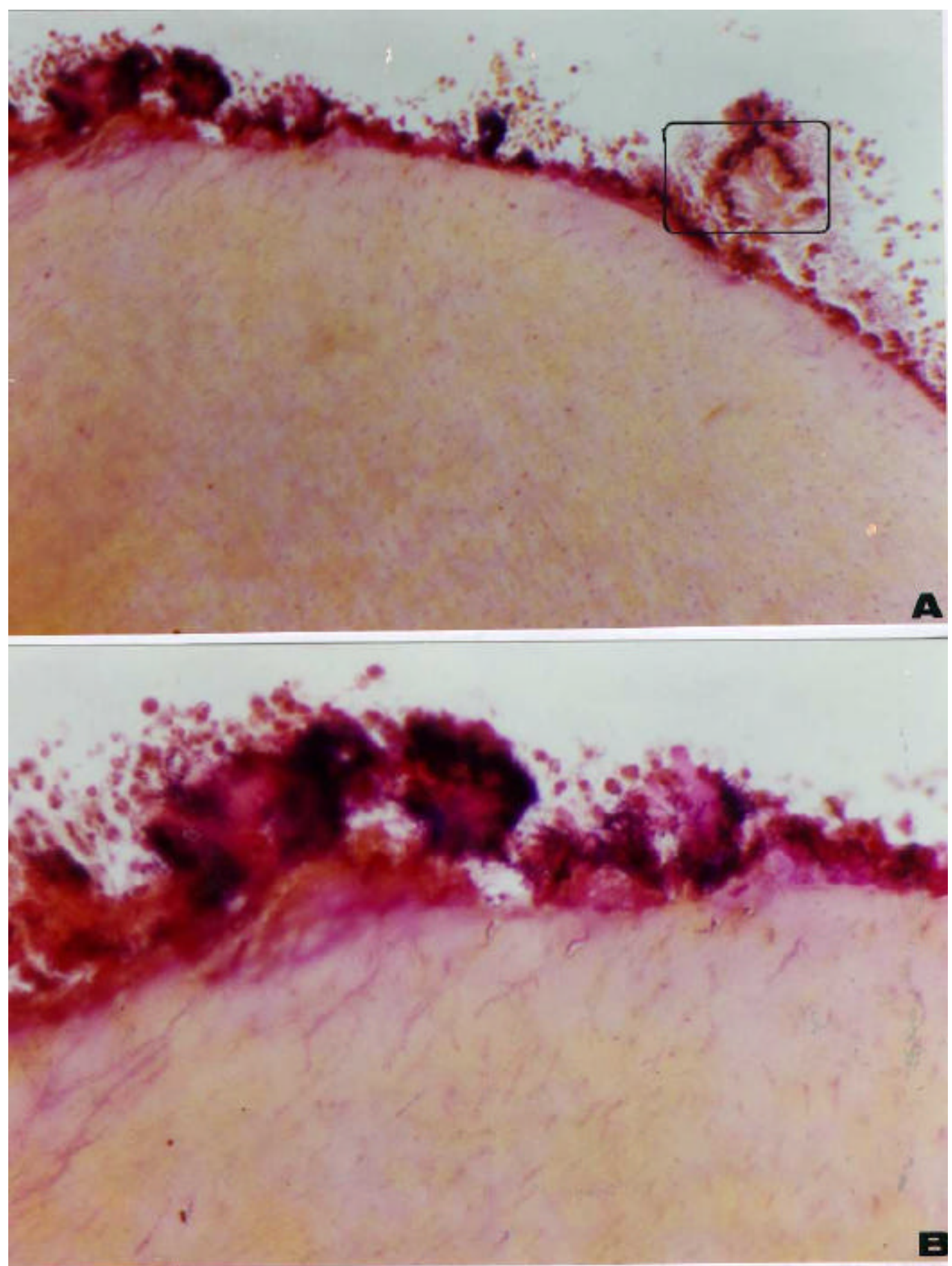

FIGURA 19 - Colonização da superfície dentária radicular apical externa por bactérias planctônicas, colônias bacterianas e biofilmes microbianos. Destaca-se 

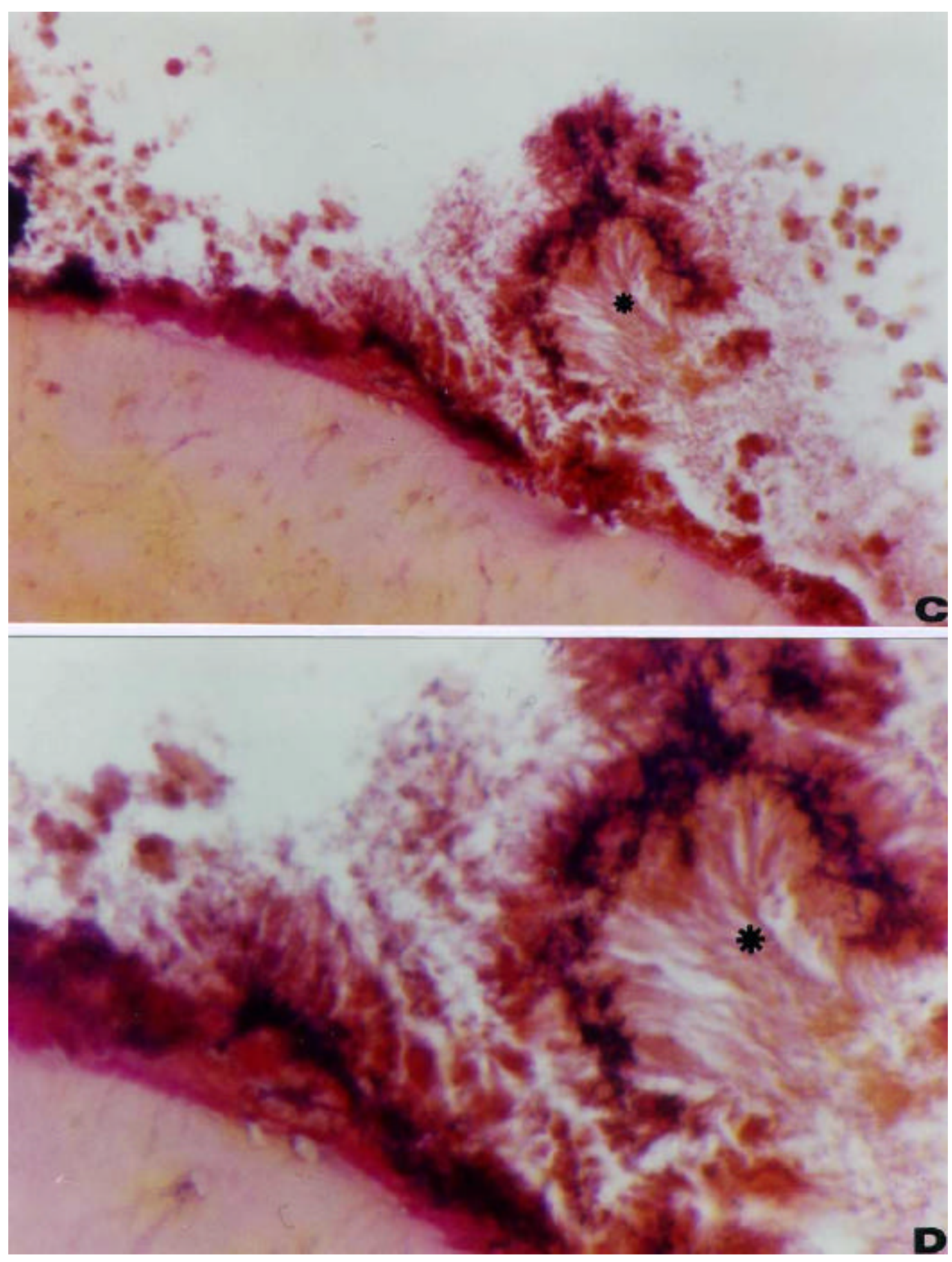

... formações bacterianas em forma de escovas (*) e componentes Gram-positivos e Gram-negativos. (B.B.; aumento original: $A=40 X$; $B$ e $C=100 X ; D=160 X)$ 
6 DISCUSSÃO 


\section{DISCUSSÃO}

$\mathrm{O}$ aspecto marcante da concepção da presente pesquisa trafega pela grande e contínua preocupação em preservar a dentadura decídua com comprometimento pulpar. Assim dois questionamentos nos impulsionaram a realizá-lo. No primeiro, em dentes decíduos com pulpite clinicamente importante ou necrose onde se localizam as bactérias? No segundo, as bactérias teriam influência no prognóstico?

A aproximação das bactérias no interior do canalículo, nas imediações da polpa, em geral de $0,5 \mathrm{~mm}$ a $1,0 \mathrm{~mm}$ de distância, ocorre simultaneamente à instalação de uma evidente resposta inflamatória pulpar (Figura 7). Nesta fase, não há uma infecção pulpar francamente caracterizada, a resposta inflamatória é induzida mais pela ação dos produtos bacterianos sobre as células, inicialmente os odontoblastos. As células agredidas odontoblásticas ou não, geram proteínas livres e podem secretar citocinas e fatores de crescimento, bem como filetes nervosos podem liberar neuropeptídeos. Conjuntamente esses mediadores desencadeiam os fenômenos iniciais da inflamação ${ }^{23}$. Ocorre um aumento da velocidade da corrente circulatória, edema, centralização de hemácias e marginação leucocitária. Evidentemente que o quadro microscópico vai se modificando e agravando, notando-se intensa atividade leucocitária principalmente de polimorfonucleares neutrófilos ${ }^{7,22}$.

No estabelecimento e progressão das pulpites, vários fatores interferem na sua etiopatogenia: alguns são inerentes ao agente agressor e outros 
decorrem do hospedeiro, incluindo a variabilidade morfológica e modificações estruturais e funcionais do complexo dentinopulpar. Ao mesmo tempo, pode haver a contaminação bacteriana interagindo com o tecido pulpar adjacente ${ }^{22}$.

A necrose pulpar significa a inviabilidade da polpa enquanto tecido: suas células estão destruídas e sua estrutura totalmente comprometida, incluindo-se os vasos e nervos. A necrose tecidual pode ser determinada pelo tipo de agente agressor e pelas propriedades do tecido envolvido. A ação de bactérias, especialmente os estafilococos e estreptococos, desencadearia um processo inflamatório agudo e uma exuberante interação destes microrganismos com os polimorfonucleares neutrófilos por meio da fagocitose ${ }^{22}$.

Em 1894, MILLER ${ }^{59}$ observou pela primeira vez a presença de bactérias em polpas necróticas de dentes humanos, correlacionando-as com a etiopatogenia das doenças pulpares. A partir, deste trabalho, diferentes métodos têm sido aplicados com o intuito de avaliar a microbiota dos tecidos pulpares infectados. Estes incluem meios de cultura $3,4,11,12,13,16,17,21,26,27,28,30,31,33,34,38,39,40,41,44,46,52,56,57,58,60,70,83,89,91,94,97,98,99,103,104,106,107$

técnica da imunofluorescência indireta ${ }^{10}$ microscopia de contraste de fase e de campo escuro $^{14,26,31,60,95}$, microscopia óptica empregando a coloração de Brown e Brenn ${ }^{1,10,43,49,53,56,63,67,70,76,79,80}$, microscopia óptica empregando a coloração de $\operatorname{Gram}^{17,20,47,69,75,87}$ e microscopia eletrônica ${ }^{18,29,33,43,54,63,64,65,70,84,88,99,100}$.

A avaliação microscópica dos cortes semi-seriados longitudinais e transversais dos espécimes corados pela técnica hematoxilina-eosina de Harris e 
Brown e Brenn permitiu-nos estudar nitidamente aspectos morfológicos da câmara pulpar, canais radiculares, úbulos dentinários, áreas de reabsorção e região apical dos dentes decíduos, com pulpite ou necrose pulpar, conforme Figuras 1 a 19.

Considerando-se a natureza polimicrobiana das infecções dos canais radiculares ${ }^{14,21,41,46,58,69,97,107}$, parece-nos que a microbiota de um ambiente pode por vezes não demonstrar todos os microrganismos devido às exigências nutricionais de certas espécies bacterianas e a competitividade determinada pela convivência num espaço restrito.

Provavelmente, os resultados diferentes evidenciados por autores que empregaram o método de cultura da microbiota dos canais radiculares, estejam também relacionados ao método de obtenção das amostras, meio de transporte, cultura em aerobiose apenas e tempo de incubação $O$ sucesso de uma técnica para obtenção de amostras bacteriológicas depende da habilidade em se obter amostras sem contaminação por microrganismos das áreas vizinhas, e ainda organismos representativos do sítio selecionado ${ }^{9}$. Alguns fatores fundamentais, como a acessibilidade da área a ser amostrada, contaminação do campo operatório e do instrumental, como também os métodos empregados para a avaliação da lesão, poderiam interferir nos resultados.

Desse modo, compreende-se facilmente a utilização de outros métodos para a detecção de bactérias nos tecidos da câmara pulpar e canal radicular. 
Introduzida a técnica microscópica a partir de 1931, o método de Brown e Brenn, surgiu da necessidade de se examinar bactérias Gram-positivas e Gram-negativas em cortes de tecidos incluídos em parafina ${ }^{13}$. A grande dificuldade encontrada nesta técnica está na evidenciação das bactérias Gramnegativas, que não se coram individualmente ou o fazem fracamente em algumas situações ${ }^{93}$. O processamento dos tecidos, ou seja, fixação, desmineralização, inclusão em parafina e microtomia, pode provocar a eliminação de algumas bactérias e/ou ainda a perda de sua capacidade tintorial pela técnica de Brown e Brenn ${ }^{102 .}$

Quanto às substâncias químicas empregadas na desmineralização de tecidos, observa-se perda da capacidade tintorial de bactérias Gram-positivas mais significantes com a utilização do ácido fórmico a 5\%, com o EDTA essa probabilidade torna-se bastante reduzida. Em áreas com limitado número de bactérias, pode haver o risco de resultados falso-negativos ${ }^{101}$. Possivelmente, parte das bactérias presentes nos espécimes por nós estudados não tenha sido detectada, apesar de nossos espécimes, como mencionamos no capítulo material e metódos, terem sido desmineralizados em EDTA e seguido passo a passo a técnica recomendada.

As bactérias representam os principais agentes etiológicos das alterações pulpares por possuírem potentes mecanismos de agressividade ${ }^{9,69,106}$. A coloração de Brown e Brenn levemente modificada ${ }^{93}$ permitiu evidenciar as bactérias Gram-positivas coradas em azul e as Gram-negativas em vermelho borrado localizadas na câmara pulpar, canal radicular, túbulos dentinários, 
superfície apical, periodonto e áreas de reabsorção radicular conforme Figuras 7, $8,9,10,11,12,13,14 \mathrm{~B}, 15,16,17 \mathrm{~B}, 18$ e 19.

Bactérias foram observadas em todas as amostras em cortes longitudinais devido à presença da lesão de cárie, sendo maior a sua freqüência na câmara pulpar e canais radiculares de dentes com polpas necrosadas e francamente expostas ao meio bucal. KAKERASHI; STANLEY; FITZGERARD ${ }^{49}$ também evidenciaram, pela coloração de Brown e Brenn, que a presença de microrganismos torna-se fator determinante em polpas necróticas expostas ao meio bucal.

Com o surgimento de técnicas aprimoradas para cultura em anaerobiose, registraram marcada presença de anaeróbios estritos nas infecções pulpares, determinando ser predominantemente anaeróbia a microbiota dos canais radiculares $3,12,27,28,31,33,39,40,41,46,60,89,90,91,98,99,103,105,106,107$. Os estreptococos, até então considerados invasores primários dos canais ${ }^{14,21,26,30,39,58,97}$, passaram a ocupar papel secundário na etiologia das alterações pulpares como demonstraram os trabalhos de ANDO; HOSHINO 3 , BROOK; STEPHEN; RAYMOND $^{12}$, DEBELIAN; OLSEN; TRONSTAD ${ }^{27}$, DOUGHERTY et $\mathrm{al}^{28}$, FUKUSHIMA et al ${ }^{33}$, GOMES; DRUCKER; LILLEY ${ }^{40}$, GOODMAN ${ }^{41}$, HIRAI et $\mathrm{al}^{46}$, KEREKES; OLSEN ${ }^{50}$, SUNDQVIST ${ }^{89}$, SUNDQVIST; JOHASSON; SJÖGREN $^{91}$, TOYOSHIMA et $\mathrm{al}^{98}$, WITTGOW; SABISTON ${ }^{103}$, YOSHIDA et $\mathrm{al}^{106}$, ZAVISTOSKI et $\mathrm{al}^{107}$. 
A origem das bactérias detectadas na polpa, independente da causa, é freqüentemente proveniente da microbiota bucal ${ }^{32,90,106}$, sem descartar a via hematogênica ${ }^{99}$. Segundo MAC DONALD; HARE; WOOD $^{57}$ a maioria das bactérias alcança a polpa dos dentes que sofreram trauma dentário sem fratura, pelos vasos linfáticos e sangüíneos do periodonto, podendo ser causa da necrose pulpar. Na figura 11 nota-se a presença de bactérias planctônicas e colônias em polpa inflamada e relacionada diretamente com a cárie na dentina.

Os trabalhos de BROWN; RUDOLPH ${ }^{14}$, MAC DONALD; HARE; WOOD $^{57}$, WITTGOW; SABISTON ${ }^{103}$ relatam que a polpa necrótica de dentes com coroa intacta relacionada a traumas nem sempre encontravam-se infectadas. A microbiota dos canais radiculares é extremamente dinâmica, desenvolvem-se fortes interações entre diferentes espécies microbianas resultando em mudanças ambientais $^{89,90}$.

O processo inflamatório pode expandir-se rapidamente da polpa para os tecidos periodontais com a invasão dos microrganismos e seus produtos. Neste trabalho encontramos em vários espécimes a presença de cocos, bacilos predominantemente Gram-positivos livres, e em colônias dispersos no periodonto lateral de dentes com pulpite e necrose. Estes podem ter alcançado esta área por meio de comunicações polpa-periodonto em decorrência do processo de reabsorção (Figuras 16 e 17), canais acessórios e forame apical. Sem descartar, a possibilidade da penetração de microrganismos e/ou produtos pela via periodontal, pois, em decorrência do avanço do processo de reabsorção radicular, os decíduos adquirem graus variados de mobilidade resultante do 
trauma mecânico e conseqüente inflamação. TOMIC-KAROVIC; JELINEK ${ }^{97}$ observaram que a microbiota dos tecidos aos arredores do dente e do alvéolo de molares decíduos necrosados incluem organismos potencialmente patogênicos com predomínio de Streptococcus salivarius.

A inflamação crônica do canal radicular ou do ligamento periodontal pode representar uma entrada persistente de bactérias para a circulação sangüínea. Cuidados devem ser tomados para se prevenir a disseminação para áreas não infectadas do dente e também para outras regiões do corpo humano como foi enfatizado por KEREKES; OLSEN ${ }^{50}$.

Dentes com pulpite revelaram cocos e bacilos Gram-positivos e Gram-negativos, predominantemente livres e em colônias em contato direto com a polpa e no interior da polpa (Figura 11). Existe a possibilidade de que a coloração, apesar das modificações introduzidas, não tenha sido eficiente para demonstrar todas as bactérias Gram-negativas presentes nos tecidos avaliados ou seja estes resultados estão subdimensionados, tornando-os mais significantes ainda.

Os dentes com necrose apresentaram cocos e bacilos Gram-positivos e Gram-negativos e espirilos Gram-negativos livres, formando colônias permeadas ou não por células do exsudato inflamatório ou restos necróticos nos tecidos pulpares da coroa e raiz, ou constituindo biofilmes ao longo de suas paredes dentinárias, às vezes penetrando nos túbulos dentinários (Figuras $15 \mathrm{e}$ 16). Como em nossso estudo selecionamos dentes com polpa inflamada e necrosada, em consequiência do processo de cárie, já era esperado uma intensa e 
variada quantidade de bactérias planctônicas, em colônias e biofilmes microbianos nos tecidos dentários dos espécimes com necrose pulpar. SHOVELTON $^{87}$ estudando a distribuição de bactérias ao longo dos vários tecidos dentários também pôde constatar em dentes com necrose pulpar bactérias na câmara pulpar e/ou canal radicular da maioria dos espécimes, às vezes penetrando no interior dos túbulos dentinários. Os dentes com abscesso agudo periapical apresentavam pouco número de organismos em comparação com os dentes que apresentavam infecção crônica. Nos dentes com vitalidade e exposição por cárie, grande número de organismos foi observado na superfície da polpa com ausên cia de invasão bacteriana na dentina na região da câmara pulpar e canal radicular. No grupo de dentes com ausência de cárie e polpa normal não foram detectadas bactérias.

Verificamos que os morfotipos bacterianos sofreram modificações quanto à localização, se na câmara pulpar ou canais radiculares. Na câmara pulpar, observamos cocos e bacilos Gram-positivos e Gram-negativos prevalecendo os Gram-positivos, provavelmente devido à profundidade e extensão dos processos de cárie e tempo de exposição de nossas amostras. Nos canais radiculares encontramos predominantemente cocos e bacilos Grampositivos e Gram-negativos com prevalência de Gram-negativos. Em pesquisa realizada em macacos, FABRICIUS et $\mathrm{al}^{31}$ também evidenciaram que era variável a distribuição das diferentes espécies bacterianas nos canais radiculares em função dos diferentes períodos de exposição pulpar. Notaram no terço apical predomínio de bacilos Gram-positivos e Gram-negativos anaeróbios estritos, os 
quais desempenhariam papel fundamental na etiologia e manutenção das lesões periapicais.

O processo de necrose na polpa dentária com inflamação e contaminação bacteriana geralmente se estende no sentido da superfície pulpar coronária para o ápice. Geralmente a ultima área pulpar a evoluir para a necrose corresponde ao terço apicat ${ }^{49}$. As alterações bacterianas observadas na câmara pulpar e nos diferentes terços dos canais, podem ser explicados pelas condições criadas pelas alterações patológicas na polpa dentária, tais como a diminuição do potencial de óxido redução e a disponibilidade de nutrientes ${ }^{30,89,90}$. Nos biofilmes microbianos, as bactérias unidas umas às outras por uma matriz de polissacarídeos e aderidas a uma superfície inerte ou viva permitem sua sobrevivência em ambientes hostis. Conservadas em um ecossistema cooperativo, as diferentes bactérias tornam-se mais fortalecidas ${ }^{25,73,74,85}$.

Vários trabalhos demonstraram uma ou mais camadas de células bacterianas, formando densas colônias, com morfologia variada, relacionadas às paredes dentinárias. Algumas bactérias também permaneciam livres entre o vasto número de polimorfonucleares no conteúdo aquoso do canal radicular, possivelmente nos canais ocorram fenômenos de aderência bacteriana e estabelecimento de comunidades entre os microrganismos ${ }^{1,10,54,64,65,76,84}$. Assim como em nossos espécimes, evidenciaram-se biofilmes microbianos nas paredes dentinárias (Figura 15). Os biofilmes não são eliminados pelas células e mediadores inflamatórios ou imunológicos devido às suas dimensões; enquanto as células sangüíneas com aproximadamente $15 \mu \mathrm{m}$ de diâmetro podem 
identificar e fagocitar as bactérias livres, o mesmo não ocorre com os biofilmes que podem atingir $50 \mu \mathrm{m}$ a $100 \mu \mathrm{m}$ de diâmetro ${ }^{74}$.

Em dois espécimes com pulpite pudemos observar a presença de canal acessório na raiz de molar. Estes pareciam não estabelecer comunicação direta polpa-periodonto e não apresentavam bactérias. NAIR et $\mathrm{al}^{65}$, observaram canais radiculares tratados endodonticamente e com lesão periapical persistente, por meio da microscopia óptica e eletrônica de transmissão e encontraram predominantemente cocos, bacilos e espirilos Gram-positivos agregados ou isolados, livres ou aderidos à parede dentinária no interior de canais acessórios.

A dentina é a mais permeável dos tecidos dentários, em função de sua estrutura canalicular. A permeabilidade da dentina nos decíduos está em relação direta com o número e o diâmetro dos túbulos dentinários ${ }^{35,51}$. Enfatizando-se que se o processo odontoblástico morre seguindo a morte da polpa ou injúria periférica e são expostos ao meio bucal, estes ficam propensos à invasão pelas bactérias presentes ${ }^{20}$.

Os túbulos dentinários encontravam-se predominantemente preservados e a densidade intratubular oscilou entre leve e moderada. Nos cortes longitudinais, pôde-se verificar na dentina coronária e região do teto da câmara pulpar, em virtude do processo de cárie, que a densidade foi intensa e alguns túbulos apresentavam-se dilatados, varicosos e ainda com focos de liquefação (Figuras 7, 8, 9 e 10). 
Nos espécimes com pulpite verificou-se a presença de cocos, bacilos Gram-positivos e Gram-negativos livres, em colônias externas e biofilmes microbianos externos penetrando em túbulos dentinários atingindo o teto, câmara pulpar e raras vezes na dentina radicular e apical (Figuras 11 e 12).

Nos espécimes com necrose pulpar, as bactérias localizavam-se preferencialmente no teto e parede lateral da câmara pulpar. Quando havia grandes quantidades de bactérias, os túbulos dentinários radiculares e apicais foram invadidos por microrganismos (Figuras 15, 16 e 17). Observações semelhantes foram encontradas nos trabalhos de AKPATA; BLECHMAN ${ }^{1}$, $\operatorname{LOVE}^{56}$ que avaliaram a penetração bacteriana nos terços radiculares de dentes permanentes e verificaram que a extensão de penetração bacteriana nos túbulos dentinários do terço apical é significantemente menor em comparação aos terços médio e cervical da raiz. Estes achados favorecem as técnicas que preconizam uma preparação apical mínima, com alargamento coronalmente mais acentuado removendo-se grande quantidade de dentina infectada nos terços cervical e médio como LOVE ${ }^{56}$ descreveu.

A distribuição e profundidade de penetração nos túbulos foi variável, enquanto grupos de bactérias eram evidentes em alguns túbulos, outros estavam isentos. Na maioria das amostras, as bactérias encontravam-se no terço pulpar estendendo-se até o terço médio da dentina. Especialmente nos espécimes com necrose pulpar evidenciamos bactérias atingindo o terço superficial. Aos cortes longitudinais na região da lesão de cárie, encontram-se bactérias distribuídas nos 
terços superficial, médio e pulpar da maioria dos espécimes. Em nenhum caso as bactérias atingiram a dentina atravessando cemento.

O microambiente dos túbulos dentinários parece favorecer a seleção de algumas espécies de bactérias independentemente da etiologia do processo infeccioso. Estes constituem um importante reservatório dos canais radiculares infectados, podendo reinfectá-los durante e após o tratamento pulpar ${ }^{66}$. Pela coloração de Brown e Brenn pudemos observar cocos e bacilos Gram-positivos e Gram-negativos. Os cocos e bacilos Gram-negativos foram os morfotipos bacterianos predominantes.

A profundidade de penetração bacteriana nos túbulos dentinários relaciona-se a uma série de fatores, tais como: localização dos túbulos, morfologia, terço radicular envolvido, tipo e morfologia bacteriana, grau de infecção, tempo de inoculação, cavidades abertas ou fechadas e idade

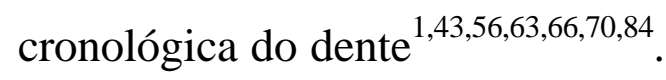

$\mathrm{Na}$ tentativa de isolar a lesão de cárie do tecido pulpar, ocorre a formação de barreira de tecido mineralizado sobre o remanescente pulpar ${ }^{7,49}$. Notou-se que esta dentina reacional tardiamente formada apresentava-se desorganizada e freqüentemente com cocos e bacilos Gram-positivos e Gramnegativos em seu interior (Figuras 7 e 12). RAYNER; SOUTHAM ${ }^{75}$ evidenciaram em $32 \%$ da amostra bactérias confinadas na dentina reparatória em molares decíduos. A presença de organismos nos túbulos dentinários ou dentina reacional em dentes decíduos é de grande interesse pois, embora em "silêncio 
clínico" a exposição durante o processo de reabsorção poderia conduzir a uma reinfecção dos tecidos circunvizinhos ${ }^{47}$.

Em nossos espécimes notamos cocos e bacilos Gram-positivos e Gram-negativos no interior de túbulos dentinários na região do soalho da câmara pulpar (Figura 13), corroborando com $\mathrm{HOBSON}^{47}$ que também evidenciou microrganismos no interior dos túbulos dentinários nesta região, sugerindo que seus produtos metabólicos possam ter acesso à área inter-radicular explicando a típica imagem radiolúcida encontrada em molares decíduos necrosados.

MORABITO; DEFABIANIS ${ }^{61}$, RINGELSTEIN; SEOW $^{78}$ têm atribuído à localização inter-radicular das alterações patológicas observadas em molares decíduos com necrose pulpar a presença de canais acessórios. Estes, determinariam comunicações aberrantes entre a polpa e os tecidos periodontais ao longo dos quais bactérias e suas toxinas ou os produtos da decomposição tecidual poderiam se difundir, com resultante destruição do tecido ósseo alveolar adjacente caracterizando o que se denomina "patologia da furca".

Observamos, entretanto, a presença de canal acessório em apenas um dos espécimes em corte longitudinal na região do soalho da câmara pulpar e em um espécime em corte transversal na região do terço cervical da raiz, apesar da realização de cortes semi-seriados.

Embora não fosse escopo deste trabalho, nos parece lícito que a localização inter-radicular das alterações patológicas não poderia ser totalmente 
explicada pela presença de canais acessórios possibilitando a difusão do processo inflamatório a partir da câmara pulpar.

Acreditamos que a menor espessura de dentina, aliada à reabsorção radicular fisiológica e exposição de túbulos dentinários, além da eventual presença de canais acessórios aumentam a permeabilidade dentinária dos decíduos facilitando a progressão de microrganismos e seus produtos em direção aos tecidos periodontais. A presença de lesão inflamatória na região interradicular determinaria em função da aceleração do processo de rizólise e diminuição da espessura de dentina, aumento ainda maior da permeabilidade na região do soalho da câmara pulpar. A partir da análise em microscopia eletrônica de varredura, GODOY ${ }^{36}$, GODOY; PAVARINI; CONSOLARO ${ }^{37}$, informaram que a dentina da região do soalho da câmara pulpar de dentes decíduos em rizólise comporta-se como uma verdadeira "peneira biológica", caracterizada por uma considerável permeabilidade em função de sua porosidade estrutural.

Deve-se enfatizar que os microrganismos exibem um papel fundamental na progressão das lesões periapicais em dentes decíduos ${ }^{12,21,30,47,98}$. A patologia de furca relaciona-se a eventuais distúrbios, como o deslocamento ${ }^{98}$ e interferência na formação do germe do dente permanente subjacente ${ }^{8}$. Essas alterações poderiam variar desde uma hipoplasia do esmalte (dente de Turner) ou até mesmo a detenção do desenvolvimento do dente permanente e sua esfoliação ou formação de cisto folicular inflamatório ${ }^{24}$. 
A presença de bactérias nos túbulos dentinários de dentes decíduos expostos à superfície radicular durante o fenômeno de rizólise pode estar relacionado com a persistência de lesões periapicais após terapia endodôntica. Possivelmente, em muitos casos de canais radiculares prontos para serem obturados, se realizarmos testes de cultura bacteriana, o resultado será negativo, todavia poderão existir bactérias confinadas nos túbulos dentinários ${ }^{17}$. Isto indica que, o resultado de um teste bacteriológico, não permite afirmar a presença ou ausência de bactérias no sistema de canal radicular, embora tenha seu valor, seu uso na prática endodôntica restringe-se a determinadas situações ${ }^{19}$.

Não foi por nós proposto, associar espécies bacterianas com sinais e sintomas clínicos, mas segundo GOMES; LILLEY; DRUCKER ${ }^{39}$, HASHIOKA et $\mathrm{al}^{44}$, YOSHIDA et $\mathrm{al}^{106}$ muitos sinais e sintomas clínicos evidenciados nos canais radiculares de dentes infectados estão relacionados com espécies bacterianas específicas.

A característica de transitoriedade dos dentes decíduos, relacionada pelo ciclo biológico desses dentes, determina intensas modificações na anatomia radicular. Em condições fisiológicas estas transformações estão representadas pelo processo de reabsorção radicular dos decíduos e erupção dos permanentes (Figuras 15A, 16, 17 e 18).

Durante a reabsorção fisiológica dos decíduos, as células inicialmente dispõem-se diretamente sobre a superfície da raiz destruindo o cemento. A 
princípio a superfície cementária assume um aspecto rugoso, e em seguida as células introduzem-se dentro do tecido com formação de cavidades muito próximas umas das outras ${ }^{68}$, as lacunas de Howship (Figura 17).

Os clastos, conjuntamente com os osteoblastos e macrófagos, constituem as unidades osteorremodeladoras instaladas no tecido adjacente à superfície a ser reabsorvida ${ }^{62,82,92}$. A reabsorção dos dentes decíduos constitui-se em um processo fisiológico que determina importantes alterações na morfologia das raízes e principalmente na posição do forame apical ${ }^{36,37}$. A microscopia óptica possibilitou verificarmos clastos ora multi, ora mononucleados reabsorvendo ativamente cemento e dentina radicular resultando em defeitos irregulares e profundos, modificando o contorno regular externo das raízes dos espécimes (Figuras 15A, 16, 17,e 18). Também constatamos a presença de áreas reabsorvidas na parede interna do canal radicular conforme Figuras 14 e 15.

O processo inflamatório pulpar decorrente do envolvimento microbiano e seus produtos via cárie ou traumatismo ${ }^{96}$, estendendo-se para os tecidos periodontais e foliculares vizinhos, pode trazer grande quantidade e variedade de citocinas e fatores de crescimento acelerando o processo de rizólise.

Na região apical, áreas de reabsorção radicular estavam presentes em todos os espécimes com pulpite e necrose pulpar (Figura 18). Já era esperado encontrarmos áreas reabsorvidas em nossas amostras em virtude do processo fisiológico de reabsorção dos decíduos, estas poderiam estar mais avançadas 
pelo grau de inflamação pulpar. Reações inflamatórias podem estar associadas às reabsorções ${ }^{49,53,99}$.

Pudemos notar em vários espécimes depósito de tecido cementóide nas áreas de reabsorção, estes depósitos de material cementóide estão relacionados com a tentativa de remodelação da superfície radicular reabsorvida, por meio da deposição de uma densa matriz colagenosa na qual ocorre uma mineralização salpicada. O tecido final de reparo é similar ao cemento celular, mas menos mineralizado ${ }^{81}$. Essa característica revela o padrão intermitente do processo $^{2}$ e permite-nos entender porque algumas vezes o dente decíduo apresenta-se com mobilidade e outras aderido firmemente ao alvéolo.

As anfractuosidades e irregularidades interferem na formação dos biofilmes microbianos, pois o fluxo das secreções, do exsudato, dos mediadores e dos movimentos celulares, pode dificultar a instalação de biofilmes ${ }^{42}$. Na presença de anfractuosidades e irregularidades, inicialmente as bactérias planctônicas podem aderir fragilmente às superfícies até se organizarem em comunidades $^{25}$.

Em dentes com pulpite e principalmente com necrose pulpar, nas anfractuosidades das estruturas dentinárias e/ou cementárias, grosseiramente organizadas decorrentes da reabsorção, detectamos predominantemente cocos e bacilos Gram-positivos e Gram-negativos livres, em colônias e biofilmes microbianos distribuídos no tecido dentinário da parede do canal (Figuras 14B, 
15 e 16A) e superfície externa da raiz (Figuras 16, 17B, 18 e 19), incluindo a área externa do soalho da câmara pulpar (Figura 13B).

Lacunas de reabsorção na área externa do soalho da câmara pulpar preenchida por bactérias livres, colônias e biofilmes podem estar relacionadas com a presença da lesão na região inter-radicular de molares. Nesses casos, é alta a probabilidade de insucesso do tratamento endodôntico pela impossibilidade do profissional em alcançar esta área.

Considerando os aspectos morfológicos das paredes do canal, certas regiões não são atingidas pelos instrumentos endodônticos, as bactérias enclausuradas podem manter o processo inflamatório, mesmo após o tratamento. Os insucessos endodônticos estão relacionados às áreas de reabsorção infectadas por bactérias envolvendo as paredes do canal cementário e /ou dentinários, deixando a dentina da superfície apical parcialmente desnuda e ainda pela comunicação direta de túbulos dentinários contaminados com a região periapical e dificuldade em remover-se as bactérias dessas irregularidades durante o preparo biomecânico ${ }^{17,33,53,65,99}$.

Na pulpotomia, realizada em polpas inflamadas, todo tecido inflamado da câmara pulpar deve ser removido, admitindo-se que o tecido pulpar radicular remanescente permanece sadio. Em alguns casos, a colocação de medicamentos no nível do soalho da câmara pulpar, possivelmente não será capaz de atingir todas as áreas que contêm bactérias quer seja no canal radicular ou no contorno externo da raiz e o quadro clínico poderá perfeitamente agravar-se. 
Formas cocares e bacilos Gram-positivos e Gram-negativos e alguns espirilos Gram-negativos livres, em colônias e biofilmes foram encontrados intimamente relacionados à superfície apical predominantemente em espécimes com necrose pulpar, distribuídas ao acaso nas áreas próximas da abertura correspondente ao forame apical em meio às áreas regulares e irregulares de tecido cementário e dentinário da região apical. Bactérias em tecido dentinário intratubular apical foram encontradas em sete espécimes com necrose pulpar e em um espécime com pulpite (Figuras 18 e 19). Provavelmente, as bactérias alcançaram essa região via canal radicular ou ainda periodontal, sem descartar a via hematogênica.

Devido à grande variedade de microrganismos encontrados em dentes decíduos necrosados, recomenda-se o tratamento endodôntico ou até mesmo a extração do elemento dependendo do grau de infecção e destruição ${ }^{21,97}$. Os princípios gerais preconizados nas terapias pulpares dos dentes decíduos são aqueles aplicados nos dentes permanentes, diferenciando-se às vezes quanto à droga utilizada na desinfecção do canal radicular e ao material empregado na obturação $^{48,96}$.

O tratamento endodôntico tem como meta a diminuição ou completa remoção dos produtos necróticos e microrganismos contidos no interior do sistema de canal radicular ${ }^{32,58}$. Para o sucesso da terapia endodôntica vários pesquisadores justificam o emprego de um conjunto de procedimentos como: instrumentação associada à irrigação com substâncias químicas com poder antibacteriano, emprego de curativos intracanal e selamento adequado do 
sistema de canal radicular por meio da obturação dos condutos, favorecendo a proposta inicial $^{16,71,76,79}$.

$\mathrm{Na}$ instrumentação dos canais radiculares, ocorre a formação de uma camada de lama dentinária ou "smear layer" nas suas paredes ${ }^{51}$, que se constitui primariamente por matéria inorgânica, possuindo também uma significativa porcentagem de componentes orgânicos, incluindo bactérias e seus produtos. Para DRAKE et $\mathrm{al}^{29}$, a "smear layer" pode inibir a colonização bacteriana dos canais e bloquear a penetração de bactérias dentro dos túbulos dentinários. Parece-nos que a utilização de substâncias irrigadoras durante a instrumentação pode remover se não toda, pelo menos parte dessa camada, diminuindo o número de bactérias aderidas à dentina na superfície interna do canal, como demonstrou o trabalho de CALAS et $\mathrm{al}^{18}$.

A eficiência do procedimento biomecânico e de uma pasta utilizada na obturação de canais de dentes decíduos, foi observada por GOMES; FONSECA; GUEDES-PINTO $^{38}$, nesta ocasião os resultados revelaram que a cultura foi positiva em $100 \%$ das amostras, antes e após o preparo biomecânico, seguida a obturação dos canais a cultura foi ainda positiva em $52 \%$ dos casos. Os resultados deste trabalho permitiram afirmar que a biomecânica não é suficiente na eliminação das bactérias e mesmo após a obturação mais da metade dos microrganismos permaneceram comprometendo o sucesso do tratamento. Nossos resultados contribuem para o embasamento destas afirmações. 
Em dentes decíduos com rizólise, se existe a preocupação da dificuldade da instrumentação em atingir todas as irregularidades topográficas que potencialmente contêm bactérias e seus produtos ou tecido pulpar necrótico, maior ainda serão os obstáculos para que ocorram a difusão das substâncias irrigadoras empregadas para este fim, bem como o vedamento destas regiões pelo material obturador.

Nos decíduos, os planos de reabsorção da superfície radicular ora internos, ora externos e a modificação principalmente na posição do forame apical dificultam verificar radiograficamente o comprimento da raiz a ser medida. Recomenda-se reduzir o provável comprimeto de trabalho em 1,0mm a 1,5mm como medida de segurança, evitando a sobreinstrumentação. Em polpas infectadas, esta conduta previne a disseminação de bactérias aos tecidos periodontais.

O comportamento da polpa dos dentes decíduos diante de certos procedimentos não segue sempre aquele observado para os dentes permanentes. É possível que as diferenças se devam às alterações pulpares que acompanham a reabsorção radicular fisiológica dos decíduos, responsáveis pela diminuição do potencial reparatório, como a apoptose $\mathrm{e}^{55}$. O diagnóstico preciso da verdadeira condição pulpar pode e não deve ser esquecido na avaliação de insucessos clínicos.

Os fracassos endodônticos estão relacionados à infecção bacteriana ${ }^{32,43,65,100}$. Os agentes antimicrobianos utilizados durante e após a 
instrumentação e como curativo intracanal podem ser eficazes na eliminação dos microrganismos residuais sobreviventes influenciando no prognóstico da terapia endodôntica $^{16,34,40,43,52,54,71,80,88,89}$. Efeito similar não ocorre nos biofilmes microbianos que conferem aos microrganismos certo grau de resistência às substâncias antimicrobianas, resultante da proteção pela matriz de polissacarídeos como elegantemente descreveram POTERA ${ }^{74}$ e SHEARER $^{85}$.

Quando isoladas, as bactérias quase sempre são eliminadas pelas células e mediadores inflamatórios e do sistema imunológico. Agregadas em colônias ou biofilmes microbianos, dificultam a ação das células fagocitárias, devido suas dimensões. A antibioticoterapia geralmente reverte os sintomas causados pelas bactérias liberadas a partir dos biofilmes, porém as colônias aderidas à superfície permanecem intactas. Estas revelações parecem explicar a persistência das lesões periapicais após a terapia endodôntica em vários trabalhos ${ }^{65,99,100}$ e pode relacionar-se também com insucessos da terapia em decíduos, pois encontramos bactérias formando colônias e biofilmes microbianos em nossa amostra.

O insucesso do tratamento endodôntico relaciona-se a raspas de dentina e/ou cemento lançados na região periapical durante o preparo biomecânico além de outras causas, tais como; bactérias remanescentes em túbulos dentinários expostos à superfície radicular, nas lacunas de cemento celular e nas foraminas apicais ${ }^{17,91}$. Pudemos encontrar um molar cujo ápice de uma das raízes a polpa comunicava-se com o periodonto apical por meio de três 
forames apicais, sendo que um deles apresentava-se totalmente preenchido por cocos e bacilos Gram-positivos e Gram-negativos livres e em colônias.

Se em tempos passados qualquer conduta que simplesmente eliminasse a dor ou clinicamente impedisse a evolução imediata de processos patológicos era considerada satisfatória, nos dias atuais esta óptica esta longe de preencher os quesitos necessários para ser aceita.

As dificuldades relacionadas quanto à presença de bactérias nas estruturas dos dentes decíduos não inviabilizam o tratamento endodôntico em dentes decíduos, mas deve-se enfatizar que o tratamento deve ser embasado na instrumentação associado à irrigação, curativo intracanal seguido da obturação dos canais radiculares com material biocompatível, visando a erradicação de bactérias do sistema de canal radicular ou tornando-as inviáveis, preservando o dente decíduo e evitando eventuais distúrbios na formação do germe do dente permanente. 
7 CONCLUSÕES 


\section{CONCLUSÕES}

A partir da metodologia empregada podemos verificar que:

1.Em dentes decíduos com pulpite decorrente de cárie dentária, as bactérias podem ser encontradas nos túbulos dentinários e especialmente no interior do tecido pulpar na área inflamada. Colônias bacterianas e biofilmes microbianos são visualisados na superfície cariosa e nos focos de liquefação dentinária;

2.As bactérias planctônicas, colônias bacterianas e biofilmes microbianos estão abundantemente presentes nas câmaras pulpares e canais radiculares de dentes decíduos com necrose pulpar, localizando-se nas superfícies do teto, do soalho da câmara pulpar, nas paredes laterais do canal radicular e, por extensão, nas paredes externas apicais;

3.Na estrutura dentinária de dentes decíduos com necrose pulpar, as bactérias se alojam nos túbulos dentinários da região da cárie dentária, afetandoos no sentido externo-interno e, nas paredes da câmara pulpar e do canal radicular, no sentido interno-externo;

4. No terço apical dos dentes decíduos com necrose pulpar, as bactérias se alojam nos túbulos dentinários e chegam freqüentemente até a superfície externa radicular a partir das áreas de reabsorções próprias da rizólise, estabelecendo-se colônias bacterianas e biofilmes microbianos; 
A partir destas verificações, concluímos que apesar dos procedimentos e cuidados tecnicamente assumidos e da evolução dos produtos e medicamentos colocados nas cavidades preparadas, na câmara pulpar e nos canais radiculares com finalidades de curativo de demora, obturadora e ou restauradora, não é possível clinicamente afirmar que todas as bactérias, colônias bacterianas e biofilmes microbianos serão eliminados, especialmente quando os dentes decíduos apresentam-se com necrose pulpar. 
REFERÊNCIAS BIBLIOGRÁFICAS 


\section{REFERÊNCIAS BIBLIOGRÁFICAS*}

1- AKPATA, E.S.; BLECHMAN, H. Bacterial invasion of pulpal dentin wall in vitro. J. dent. Res., v.61, n.2, p.435-8, Feb. 1982.

2- ANDIA-MERLIN, R.Y.; ARANA-CHAVES, V.E. Exame das superfícies em reabsorção de raízes de molares decíduos com pulpite crônica e lesão inter-radicular através de M.E.V. In: REUNIÃO ANUAL DA SBPqO, 11, Águas de São Pedro, 1994. Anais. São Paulo, SBPqO, 1994. v.10, p.160-7.

3- ANDO, N.; HOSHINO, E. Predominant obligate anaerobes invating the deep layers of root canal dentin. Int. Endod. J., v.23, n.1, p.20-7. 1990.

4- BENFATTI, S.V.; ANDRIONI, J.N. "In Vitro" study of drugs used in endodontic treatment of deciduous teeth. Rev. Ass. paul. cirurg. Dent.,v.23, p.213-8, Nov./Dec. 1969.

5- BENFATTI, S.V.; TOLEDO, O.A. Topografia dos canais radiculares dos molares decíduos. Rev. Fac. Odont. Araçatuba, v.2, n.1/2, p.104-21, jan./fev.1966.

\footnotetext{
*Normas recomendadas para uso no âmbito da Universidade de São Paulo, com base no documento "Referências Bibliográficas: exemplos", emanado do Conselho superior do Sistema Integrado de Biblioteca da USP, em reunião de 20 de setembro de 1990.
} 
6- BENFATTI, S.V.; ANDRIONI, J.N.; TOLEDO, O.A. Estudo morfológico dos ápices radiculares de molares decíduos. Arq. Cent. Est. Fac. Odont. Araçatuba, v.4, n.1, p.7-16, 1967.

7- BERGENHOLTZ, G. Inflammatory response of the dental pulp to bacterial irritation. J. Endod., v.7, n.3, p.100-4, Mar. 1981.

8- BINNS, W.H.; ESCOBAR, A. Defects in permanent teeth following pulp exposure of primary teeth. J. Dent. Child., v.34, n.1, p.4-14, Jan. 1967.

9- BIRCH, R.H; MELVILLE, T.H; NEUBERT, E.W. A comparison of root canal and apical lesion flora. Brit. dent. J., v.116, p.350-52, Apr. 1964.

10- BOHÓRQUEZ AVILA, S.P. Avaliação da presença e localização de bactérias nos canais radiculares e as lesões periapicais crônicas pelo método de coloração de Brown e Brenn e pela imunofluorescência indireta para Prevotella intermedia. Bauru. 1994. 128 p. Dissertação (Mestrado) - Faculdade de Odontologia de Bauru, Universidade de São Paulo.

11- BONOW, M.L.M.; PINTO, A .C.; BAMMANN, L.L. Antimicrobial activity of drugs used in pulp therapy of deciduous teeth. Braz. Endod. J., v.1, n.1, p.44-48, 1996. 
12- BROOK, I.; STEPHEN, G.; RAYMOND, B.K. Bacteriology of acute periapical abscess in children. J. Endod., v.7, n.8, p.378-80, Aug. 1981.

13- BROWN, J.H.; BRENN, L. A method for the differential staining of Grampositive and Gram-negative bacteria in tissue sections. Bull. Johns Hopk. Hosp., v.68, n.2, p.69-73, 1931.

14- BROWN, L.R.; RUDOLPH, C.E. Isolation and identification of microorganisms from unexposed canals of pulp-involved teeth. Oral Surg., v.10, n.10, p.10949, Oct. 1957.

15- BUSSCHER, H.J.; BOS, R.; VAN DER MEI, H.C. Initial microbial adhesion is a determinant for the strength of biofilm adhesion. FEMS Microbiol. Lett., v.128, n.3, p.229-34, 1995.

16- BYSTRÖM, A.; SUNDQVIST, G. Bacteriologic evaluation of the effect of 0,5 percent sodium hypochlorite in endodontic therapy. Oral Surg., v.55, n.3, p.307-12, Mar. 1983.

17- BYSTRÖM, A. et al. Healing of periapical lesions of pulpless teeth after endodontic treatment with controlled asepsis. Endod. dent. Traumat., v.3, n.2, p.58-63, Apr. 1987. 
18- CALAS, P. et al. In vitro adhesion of two strains of Prevotella nigrescens to the dentin of the root canal the parte played by different irrigation solutions. J. Endod., v.24, n.2, p.112-5, Feb. 1998.

19- CALTABIANO, A.C.; RIBEIRO, J.F.; CAMARGO, H.A. Bacteriological tests in endodontia: critical review of the literature. Rev. gaúcha Odont., v.25, n.1, p.12-4, jan./mar. 1977.

20- CHIRNSIDE, I.M. Bacterial invasion of non-vital dentin. J. dent. Res., v.40, n.1, p. 134-40, Jan/Feb. 1961.

21- COHEN, M.M. et al. Bacteriologic study of infected deciduous molars. Oral Surg., v.13, n.11, p.1382-6, Nov. 1960.

22- CONSOLARO, A. Alterações pulpares: correlações clínico-radiográficas e microscópicas. In: LEONARDO, M.R. Endodontia: tratamento de canais radiculares. 3. ed. São Paulo, Panamericana, 1998. p.41-61.

23- CONSOLARO, A. Cárie dentária: histopatologia e correlações clínicoradiográficas. Bauru, Editora Consolaro, 1996.

24- CONSOLARO, A. et al. Cistos foliculares na infância: uma abordagem etiopatogênica a partir de dois casos. In: JORNADA BRASILEIRA DE 
ESTOMATOLOGIA, 20., Goiânia, 1994. Anais. Goiânia, SOBE, 1994. P.73.

25- COSTERTON, J.W.; STEWART, P.S.; GREENBERG, E.P. Bacterial biofilms: a common cause of persistent infections. Science, v.284, n.5418, p.1318-22, May 1999.

26- CRAWFORD, J.J.; SHANKLE, R.J. Application of newer methods to study the importance of root canal and oral microbiota in endodontics. Oral Surg., v.14, n.9, p.1109-23, Sept. 1961.

27- DEBELIAN, G.J.; OLSEN, I.; TRONSTAD, L. Bacteremia in conjunction with endodontic therapy. Endod. dent. Traumat., v.11, n.3, p.142-9, June 1995.

28- DOUGHERTY, W.J. et al. Black-pigmented bacteria in coronal and apical segments of infected root canals. J. Endod., v.24, n.5, p.356-8, May 1998.

29- DRAKE, D.R. et al. Bacterial retention in canal walls in vitro: effect of smear layer. J. Endod., v.20, n.2, p.78-82, Feb. 1994.

30- EDWARDS, S.; NORD, C.E. Identification and characterization of microorganisms isolated from infected primary teeth. J. Int. Ass. dent. Child., v.3, n. , p.15-8, 1972. 
31- FABRICIUS, L. et al. Predominant indigenous oral bacteria isolated from infected root canals after varied times of closure. Scand. J. dent. Res., v.90, n.2, p. 134-44, Apr. 1982.

32- FARBER, P.A.; SELTZER, S. Endodontic microbiology. I Etiology. J. Endod., v.14, n.7, p.363-71, July 1988.

33- FUKUSHIMA, $\mathrm{H}$. et al. Localization and identification of root canal bacteria in clinically asymptomatic periapical pathosis. J Endod., v.16, n.11, p.534-8, Nov. 1990.

34- GENCOGLU, N.; KÜLEKÇI, G. Antibacterial efficacy of root canal medicaments. J. Nihon Univ. Sch. Dent. v.34, n.4, p.233-6, Dec. 1992.

35- GENTNER, M.R.; MEYERS, I.A.; SYMONS, A.L. The floor of the pulp chamber following pulpotomy. J. Clin. Pediatr. Dent., v.16, n.1, p.20-4, Fall 1991.

36- GODOY, V.L. Reabsorção radicular em molares decíduos: análises morfológicas macro e microscópica. Bauru, 1995. 116p. Dissertação (Mestrado) Faculdade de Odontologia de Bauru, Universidade de São Paulo. 
37- GODOY, V.L.; PAVARINI, A; CONSOLARO, A. Reabsorção radicular em molares decíduos: análises morfológicas macro e microscópicas. Rev. Dental Press de Biologia Oral , v.1, n.1, jan. 2000. (No prelo)

38- GOMES, A. M.M.; FONSECA, L.; GUEDES-PINTO, A.C. Avaliação microbiológica do preparo biomecânico e de uma pasta obturadora de canais de dentes decíduos necrosados. Rev. Odontop. Atual. Clin., v.5, n.3, p.93-101, jul./set. 1996/97.

39- GOMES, B.P.; LILLEY, J.D.; DRUCKER, D.B. Clinical significance of dental root canal microflora. J. Dent., v.24, n.1-2, p.47-55, Jan./Mar. 1996.

40- GOMES, B.P.; DRUCKER, D.B.; LILLEY, J.D. Positive and negative associations between bacterial species in dental root canals. Microbios, v. 80 , n. 325 , p. 231-43. 1994.

41- GOODMAN, A.D. Isolation of anaerobic bacteria from the root canal systems of necrotic teeth by the use of a transport solution. Oral Surg., v.43, n.5, p.766-70, May 1977.

42- GRISTINA, A.G.; NAYLOR, P.T.; MYRVIK, Q.N. Mechanisms of musculoskeletal sepsis. Orthop. Clin. North Amer., v.22, n.3, p.36371, July 1991. 
43- HAAPASALO, M.; ORSTAVIK, D. In vitro infection and desinfection of dentinal tubules. J. dent. Res., v.66, n.8, p.1375-9, Aug. 1987.

44- HASHIOKA, $\mathrm{K}$ et al. Relationship between clinical symptoms and enzymeproducing bacteria esolated from infected root canals. J. Endod., v.20, n.2, p.75-7, Feb. 1994.

45- HIBBARD, E.D.; IRELAND, R.L. Morphology of the root canals of the primary molar teeth. J. Dent. Child., v. 24, n.4, p. 250-7, 1957.

46- HIRAI, K. et al. Isolation and classification of anaerobic bacteria from pulp cavities of nonvital teeth in man. Bull Tokyo Dent. Coll, v.32, n.3, p.958, Aug. 1991.

47- HOBSON, P. Pulp treatment of deciduous teeth. Brit. dent. J., v.128, n.5, p.232-38, May 1970.

48- ISSAO, M.; GUEDES-PINTO, A.C. Manual de Odontopediatria. 8.ed. São Paulo, Artes Médicas, 1993.

49- KAKEHASHI, S.; STANLEY, H.R.; FITZGERARD, R.J. The effects of surgical exposures of dental pups in germ-free and conventional laboratory rats. Oral Surg., v.20, n.3, p.340-9, Sept. 1965. 
50- KEREKES, K.; OLSEN, I. Similarities in the microfloras of the canals and deep periodontal pockets. Endod. dent. Traumat., v.6, n.1, p.1-5, Feb. 1990.

51- KOUTSI, V. et al. The effect of dentin depth on the permeability and ultrastructure of primary molars. Pediatr. Dent., v.16, n.1, p.29-35, Jan./Feb. 1994.

52- LEONARDO, M.R. et al. In vivo antimicrobial activity of $2 \%$ chlohexidine used as a root canal irrigating solution. J. Endod., v.25, n.3, p.167-71, Mar. 1999.

53- LIN, L.M. et al. Clinical, radiografic, and histological study of endodontic treatment failures. Oral Surg, v.71, n.5, p.603-11, May 1991.

54- LOMÇALI, G.; SEN, B.H.; ÇANKAYA, H. Scanning electron microscopic observations of apical root surfaces of teeth with apical periodontitis. Endod. dent. Traumat., v.12, n.2, p.70-6, Apr. 1996.

55- LOURENÇO, S.Q.C. Reabsorção dentária fisiológica: estudo dos mecanismos (Apoptose) e das moléculas desencadeadoras (Bmp-4 e Gelatinase B) em dentes decíduos de gatos. Bauru, 1999. 104p. Tese (Doutorado) - Faculdade de Odontologia de Bauru, Universidade de São Paulo. 
56- LOVE, R.M. Regional variation in root dentinal tubule infection by Streptococcus gordonii. J. Endod., v.22, n.6, p.290-3, June 1996.

57- MAC DONALD, J.; HARE, G.C.; WOOD, A.W.S. The bacteriologic status of the pulp chambers in intact teeth found to be nonvital following trauma. Oral Surg., v.10, n.3, p.318-22, Mar. 1957.

58- MARSH, S.T.; LARGENT, M.D. A bacteriological study of the pulp canals of infected primary molars. J. Dent. Child., v.34, n.6, p.460-70, Nov. 1967.

59- MILLER, W.D. An introduction to the study of the bacterio-pathology of the dental pulp. Dent. Cosmos, v.36, n.7, p.505-28, July 1894.

60- MÖLLER, A.R. et al. influence on periapical tissues of indigenous oral bacteria and necrotic pulp tissue in monkeys. Scand. J. dent. Res., v.89, n.6, p.475-84, Dec. 1981.

61- MORABITO, A.; DEFABIANIS, P. A SEM investigation on pulpalperiodontal connections in primary teeth. ASDC J. Dent. Child., v.59, n.1, p.53-7, Jan./Feb. 1992.

62- MOSCA, O.A. Resorption surface of deciduous teeth under the scanning electron microscope. J. Int. Dent. Child., v. 14, n.1, p.3-8, June 1983. 
63- NAGAOKA, S. et al. Bacterial invasion into dentinal tubules of human vital and nonvital teeth. J. Endod., v.21, n.2, p.70-3, Feb. 1995.

64- NAIR, P.N.R. Light and electron microscopic studies of root canal flora and periapical lesions. J. Endod., v.13, n.1, p.29-39, Jan. 1987.

65- NAIR, P.N.R. et al. Intraradicular bacteria and fungi in root-filled, asymptomatic human teeth with therapy-resistent periapical lesions: a long-term ligth and electron microscopic follow-up study. J. Endod., v.16, n.12, p.580-8, Dec. 1990.

66- OGUNTEBI, B.R. Dentine tubule infection and endodontic therapy implications. Int. Endod. J., v.27, n.4, p.218-22, July 1994.

67- OLGART, L.; BRÄNNSTRÖM, M.; JOHNSON, G. Invasion of bacteria into dentinal tubules. Acta. odont. Scand., v.32, n.1, p.61-70, 1974.

68- ORBAN, B. et al Histologia e embriologia oral de Orban. 10. ed. São Paulo, Artes Médicas, 1989.

69- PATERSON, R.C.; WATTS, A. Further studies on the exposed germ-free dental pulp. Int. Endod. J., v.20, n.3, p.112-21, May 1987.

70- PEREZ, F. et al. Migration of Streptococcus sanguis strain throught the root dentinal tubules. J. Endod., v.19, n.6, p.297-301, June 1993. 
71- PETERS, L.B.; WESSELINK, P.R.; MOORER, W.R. The fate and the role of bacteria left in root dentinal tubules. Int. Endod. J., v.28, n.2, p.95-9, Mar. 1995.

72- PLÂNCTON. In: Enciclopédia Barsa. Rio de Janeiro, Encyclopaedia Britannica, v.12, p.345, 1981.

73- POTERA, C. Biofilms invade microbiology. Science, v.273, n.5283, p.1795-7, Sept. 1996.

74- POTERA, C. Forging a link between biofilms and disease. Science, v.283, n.5409, p.1837-9, Mar. 1999.

75- RAYNER, J.A; SOUTHAM, J.C. Pulp changes in deciduous teeth associated with deep carious dentine. J. Dent., v.7, n.1, p.39-42, Mar. 1979.

76- RIBEIRO, F.C. Distribuição das bactérias nas estruturas mineralizadas de dentes com necrose pulpar e granuloma apical. Bauru, 1997. 172 p. Dissertação (Mestrado) - Faculdade de Odontologia de Bauru, Universidade de São Paulo. 
77- RIBEIRO, F.C. Aspectos morfológicos dos biofilmes microbianos na osteomielite crônica supurativa e correlações endodôntica e parendodôntica. Bauru, 1999. 128p. Tese (Doutorado) - Faculdade de Odontologia de Bauru, Universidade de São Paulo.

78- RINGELSTEIN, D.; SEOW, W.K. The prevalence of furcation foramina in primary molars. Pediatr. Dent., v.11, n.3, p.198-202, Sept. 1989.

79- ROWE, A.M, BINNIE, W.H. The incidence and location of microorganisms following endodontic treatment. Brit. dent. J., v.142, n.3, p.91-5, Feb. 1977.

80- SAFAVI, K.E.; SPANGBERG, L.S.W.; LANGELAND, K. Root canal dentinal tubule desinfection. J.Endod., v.16, n.5, p.207-10, May 1990.

81- SAHARA, N. et al. Cementum-like tissue deposition on the resorbed pulp chamber wall of human deciduous teeth prior to shedding. Acta anat. (Basel) v.147, n.1, p.24-34, May 1993

82- SASAKI, T. et al. Cellular roles in physiological root resorption of deciduous teeth in the cat. J. dent. Res., v.69, n.1, p.67-74, Jan. 1990.

83- SATO, T. et al. In vitro antimicrobial susceptibility to combinations of drugs on bacteria from carious and endodontic lesions of human deciduous teeth. Oral Microbiol. Imunol., v.8, n.3, p.172-6, June 1993. 
84- SEN, B.H.; PISKIN, B.; DEMIRCI, T. Observation of bacteria and fungi in infected root canals and dentinal tubules by SEM. Endod. dent. Traumat., v.11, n.1, p.6-9, Feb. 1995.

85- SHEARER, B.G. Biofilm and the dental office. J. Amer. dent. Ass., v.127, n.2, p.181-9, Feb. 1996.

86- SHEFFER, O.L.; STORRER, D.L.M.; LOPES, M.N. Avaliação da possibilidade do preparo biomecânico dos condutos radiculares em molares decíduos. Dens, v.1, n.5, p.147-53, jan./jun. 1973.

87- SHOVELTON, D.S. The presence and distribuition of micro-organisms within non-vital teeth. Brit. dent. J., v.117, p.101-7. 1964.

88- SIQUEIRA JUNIOR, J.F.; UZEDA, M.; FONSECA, M.E.F. A scanning electron microscopic evaluation of in vitro dentinal tubules penetration by selected anaerobic bacteria. J. Endod., v.22, n.6, p.308-10, June 1996.

89- SUNDQVIST, G. Association between microbial species in dental root canal infections. Oral microbiol. Immunol, v.7, n.5, p.257-62, Oct. 1992.

90- SUNDQVIST, G. Taxonomy, ecology, and pathogenicity of the root canal flora. Oral Surg., v.78, n. 4, p.522-30, Oct. 1994. 
91- SUNDQVIST, G.; JOHANSSON, E.; SJÖGREN, U. Prevalence of backpigmented Bacteroides species in root canal infections. J. Endod. v.15, n.1, p.13-9, Jan. 1989.

92- TAKANORI, D. et al. Eletron microscopic and histochemical studies of the mononuclear odontoclast of the human. The anat. Rec., v.240, p.42-51, 1994.

93- TAYLOR, R.D. Modification of the Brown and Brenn Gram stain for the differencial staining of Gram-positive and Gram-negative bacteria in tissue sections. Amer. J. clin. Path., v.46, n.4, p.472-4, Oct. 1966.

94- TCHAOU, W.S. et al. In vitro inhibition of bacteria from root canals of primary teeth by various dental materials. Pediatr. Dent., v.17, n.5, p.351-5, Sep./Oct. 1995.

95- THILO, B.E.; BAEHNI, P.; HOLZ, J. Dark-field observation of the bacterial distribuition in root canals following pulp necrosis. J. Endod., v.12, n.5, p.202-5. May 1986.

96- TOLEDO, O.A. Odontopediatria: fundamentos para a prática clínica, São Paulo, Panamericana, 1986. 
97- TOMIC-KAROVIC, K.; JELINEK, E. Comparative study of the bacterial flora in the surroundings, the root canals and sockets of deciduous molars. Int. Dent. J., v.21, n..3, p.375-88, Sept. 1971.

98- TOYOSHIMA, Y. et al. A bacteriological study of periapical pathosis on deciduous teeth. Shoni Shinagoku Zasshi ( Jpn J. Pedod), v.26, n.3, p.449-58, 1988. (Engl Abstr).

99- TRONSTAD, L.; BARNETT, F.; CERVONE, F.; Periapical bacterial plaque in teeth refractory to endodontic treatment. Endod. dent. Traumat. v.6, n.2, p.73-7, Apr. 1990.

100- TRONSTAD, L.; KRESHTOOL, D.; BARNETT, F. Microbiological monitoring and results of treatment of extrarradicular endodontic infection. Endod. dent. Traumatol., v.6, n.3, p.129-36, June 1990.

101- WIJNBERGEN, M.; VAN MULLEM, P.J. Effect of histological decalcifying agents on number and stainability of Gram-positive bacteria. J. dent. Res., v.66, n.5, p.1029-31, May 1987.

102- WIJNBERGEN, M.; VAN MULLEM, P.J. The cumulative effect of disinfection, storage, histological fixation and demineralization on number and staining ability of Gram-positive bacteria. Int. Endod. J., v.24, n.5, p.243-8, Sept. 1991. 
103- WITTGOW, W.; SABISTON, C.B. Microorganisms from pulpal chambers of intact teeth with necrotic pulps. J. Endod, v.1, n.5, p.168-71, May 1975.

104- WRIGHT, J. et al. In vitro antimicrobial and cytotoxic effects of kri 1 paste and zinc oxide-eugenol used in primary tooth pulpectomies. Pediatr. Dent., v.16, n.2, p.102-6, Mar./Apr. 1994.

105- WU, M.K. et al. Capacity of anaerobic bacteria enclosed in a simulated root canal to induce inflammation. Int. Endod. J., v.22, n.6, p.269-77, Nov. 1989.

106- YOSHIDA, M. et al. Correlation between clinical symptoms and microorganims isolated from root canals of teeth with periapical pathosis. J. Endod., v.13, n.1, p.24-8, Jan. 1987.

107- ZAVISTOSKI, J. et al. Quantitative bacteriology of endodontic infections. Oral Surg., v.49, n.2, p.171-4, Feb. 1980. 
ABSTRACT 


\section{ABSTRACT \\ Distribution of Bacterial Plankton, Bacterial Colonies and Microbial
Biofilm on Deciduous Teeth with Pulpitis and Pulp Necrosis}

Bacteria constitutes primordial factors of dental pulp contamination of deciduous teeth, resulting in clinical and therapeutic implications. In an effort to analyze the presence of planktonic bacteria, bacterial colonies and microbial biofilm in the structures of deciduous teeth with pulpitis and pulp necrosis, 32 deciduous teeth with deep caries were used. Sixteen teeth were cut longitudinally, and the other sixteen transversally. The specimens were stained with hematoxylin and eosin and Brown and Brenn for optical microscope analysis. Based on the methodology used, we were able to see:

1. In deciduous teeth with pulpitis resulting from dental caries, bacteria can be found in the dental tubules and especially inside the pulp tissue in the inflamed area. Bacterial colonies and microbial biofilm are visible on the carious surface and on the foci of dental liquefaction;

2. Planktonic bacteria, bacterial colonies and microbial biofilm are abundantly present in the pulp chambers and root canals of deciduous teeth with pulp necrosis, located on the surfaces of the root, floor of the pulp chamber and on the lateral walls of the root canal and, throughout, on the apical surface; 
3. In dentine structure of deciduous teeth with pulp necrosis, bacteria resides in the dentine tubules in the dental caries region, affecting them in the external-internal sense and, in the pulp chamber and root canal walls, in the internal-external sense;

4. In the apical third of deciduous teeth with pulp necrosis, bacteria resides in the dentine tubules and often extend into the external root surface from the areas of resorption of rizolisis, with bacterial colonies and microbial biofilm establishing themselves.

The results yielded the conclusion that, despite the procedures and care taken and the evolution of products and medications placed in the prepared cavities in the pulp layer and root canals with the objective of slow, restorative, curative, it is clinically impossible to confirm that all bacteria, bacterial colonies and microbial biofilm will be eliminated, especially when the deciduous teeth presented pulp necrosis. 